\title{
WATER RESOURCES \\ OF SPINK COUNTY, \\ SOUTH DAKOTA
}

By LOUIS J. HAMILTON and LEWIS W. HOWELLS

\section{U.S. GEOLOGICAL SURVEY}

Water-Resources Investigations Report 96-4056

Prepared in cooperation with the

SOUTH DAKOTA GEOLOGICAL SURVEY,

SPINK COUNTY, the

JAMES RIVER WATER DEVELOPMENT DISTRICT, and the

MID-DAKOTA WATER DEVELOPMENT DISTRICT

Rapid City, South Dakota 


\title{
U.S. DEPARTMENT OF THE INTERIOR \\ BRUCE BABBITT, Secretary
}

\author{
U.S. GEOLOGICAL SURVEY
}

Gordon P. Eaton, Director

For addtional information write to:

Copies of this report can be purchased from:

District Chief

U.S. Geological Survey

1608 Mt. View Rd.

Rapid City, SD 57702
U.S. Geological Survey

Information Services

Box 25286, Mail Stop 417

Denver Federal Center

Denver, CO 80225-0046 


\section{CONTENTS}

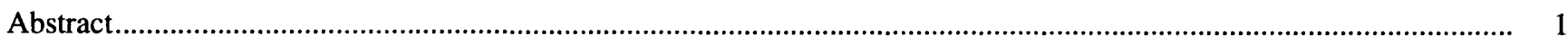

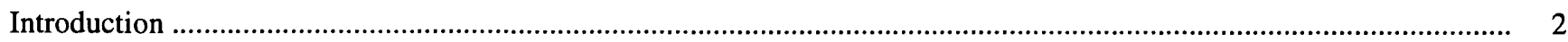

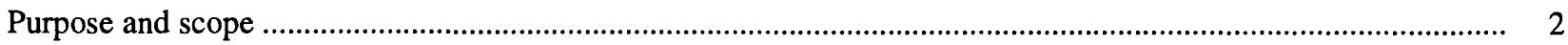

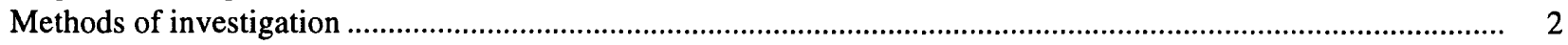

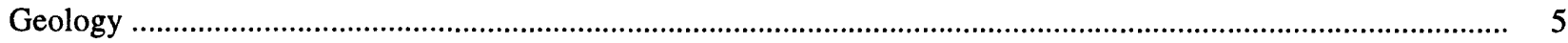

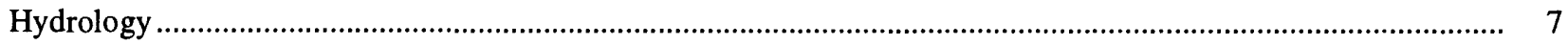

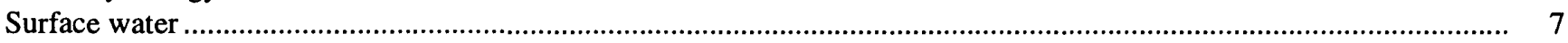

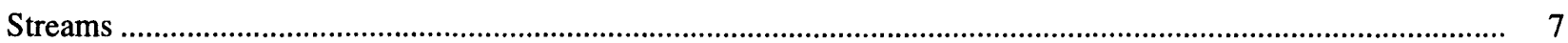

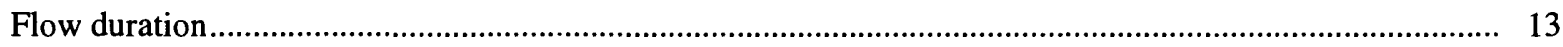

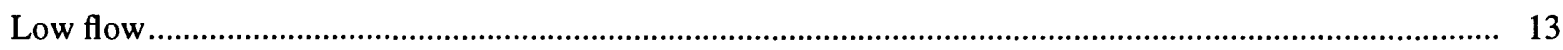

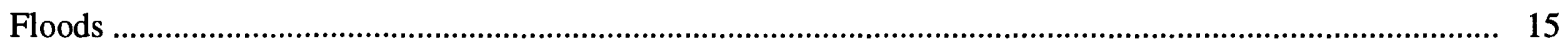

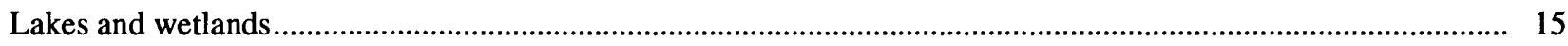

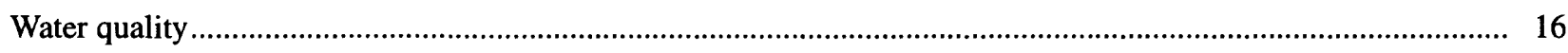

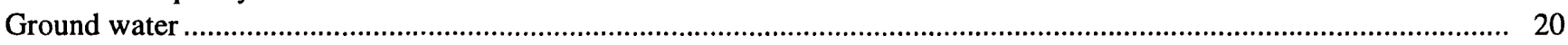

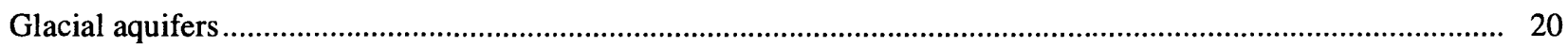

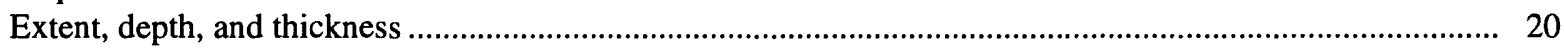

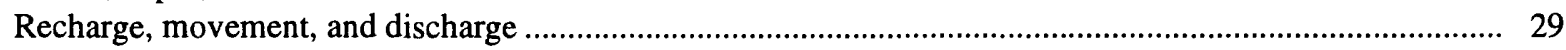

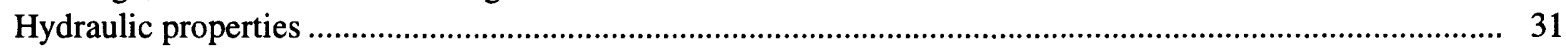

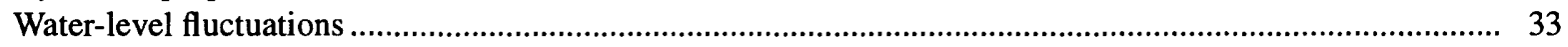

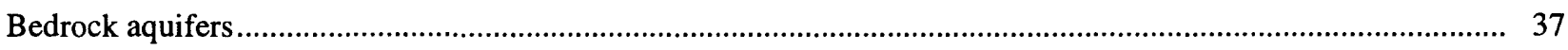

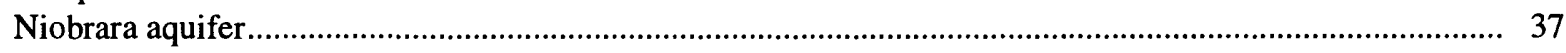

Extent, depth, thickness, and well yields .................................................................................. 37

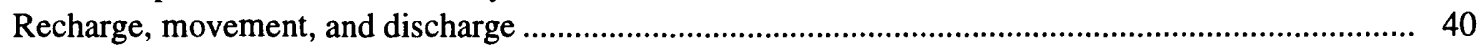

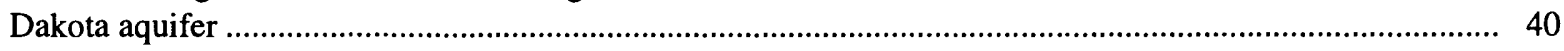

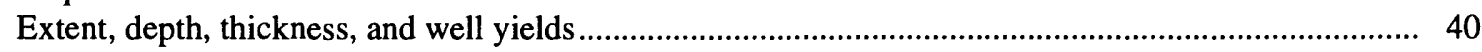

Recharge, movement, and discharge .................................................................................... 42

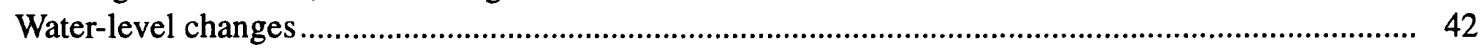

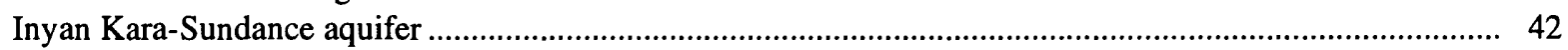

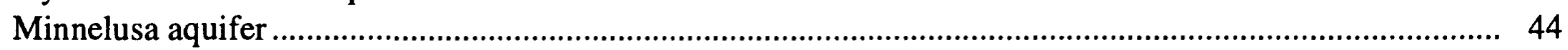

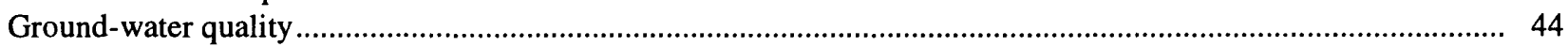

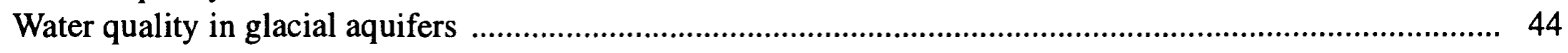

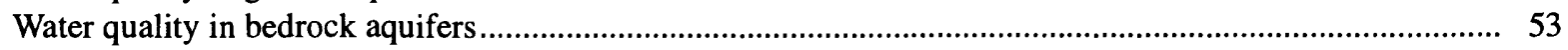

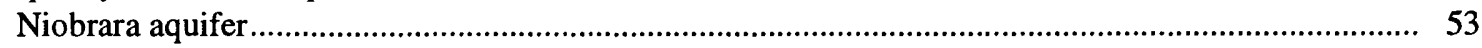

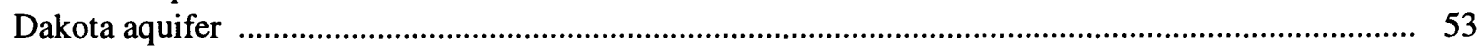

Inyan Kara-Sundance aquifer ............................................................................................. 55

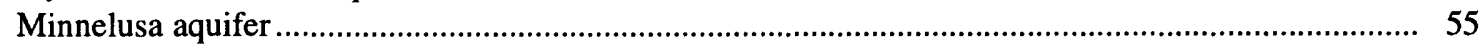

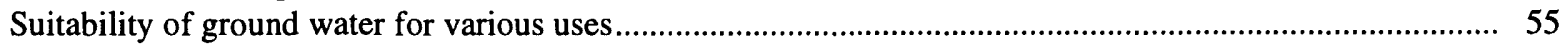

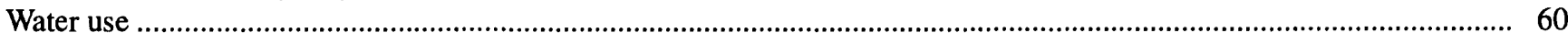

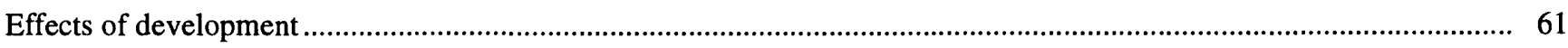

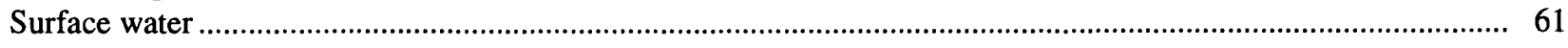

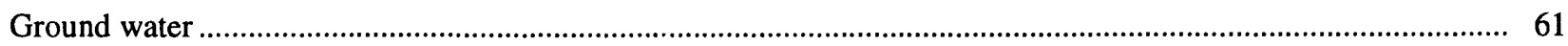

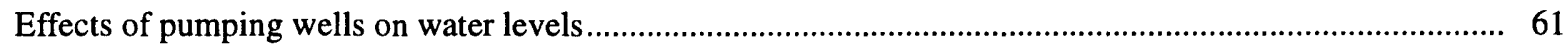

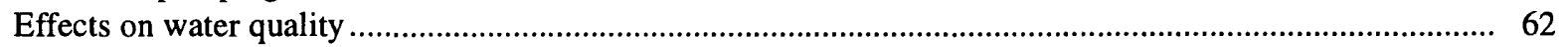

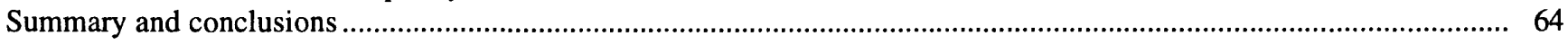

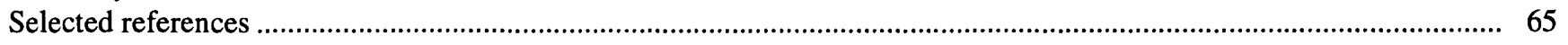




\section{ILLUSTRATIONS}

1. Index map of eastern South Dakota showing location of Spink County, status of county investigations, and locations of major physiographic divisions

2. Map showing locations of selected wells, test holes, and geologic sections in Spink County

3. Diagram of well-numbering system.

4. Map showing the topography of the bedrock surface and locations of selected wells and test holes.

5. Map showing average streamflow, middle James River Basin, and locations of selected streamflow-gaging stations, North and South Dakota.

6. Graph showing monthly distribution of average annual precipitation in Spink County and of annual discharge of the James River at three locations.

7. Graph showing annual discharge and gain or loss in flow along the James River between

Ashton and Huron during water years 1951-92

8. Duration hydrograph for daily discharges of the James River at Ashton, water years 1952-90.

9. Graph showing monthly dissolved-solids load of the James River at Huron and cumulative change in dissolved-solids loads between gaging stations from 1974-88

10. Correlation chart of major glacial aquifers in Spink County and adjacent counties.....

11.

11. Map showing extent and thickness of the Tulare, Middle James, Elm, and Altamont aquifers

12. Map showing extent, depth, and thickness of the Deep James aquifer

13. Geologic sections showing aquifers in glacial deposits:

a. Section $A-A^{\prime}$ showing the Middle James and Deep James aquifers

b. Section B-B' showing the Tulare, Middle James, and Dep James aquifers ................................................

Deep James aquifers ............................................... 26

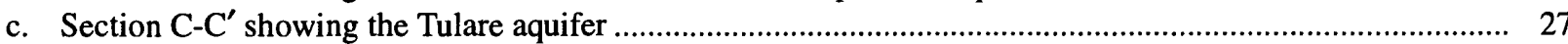

d. Section D-D' showing hte Tulare, Middle James, and Deep James........................................................... 28

14. Map showing potentiometric contours of the Tulare, Middle James, and Altamont aquifers, spring $1990 \quad \ldots \ldots \ldots . . . . .30$

15. Graphs showing water-level changes in shallow wells and cumulative departure from 1951-80 normal precipitation near Redfield 27

16. Graphs showing water-level trends in wells in glacial till and aquifers for calendar years 1951-91 and cumulative departure from 1951-80 normal precipitation near Redfield .

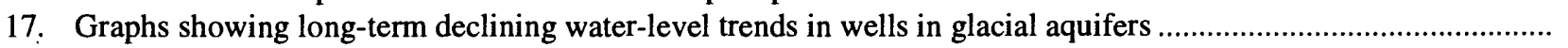

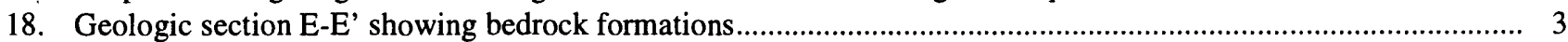

19. Map showing depth, thickness, and structure contours of the top of the Niobrara Formation which contains the Niobrara aquifer

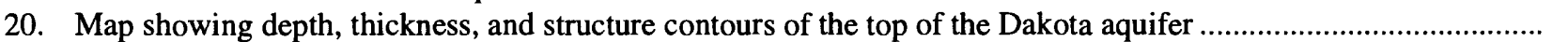

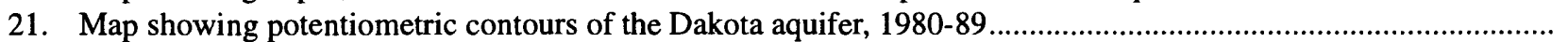

22. Graphs showing water-level changes in the Dakota aquifer

23. Map showing dissolved-solids and sodium concentrations in water from selected aquifers in glacial deposits, 1989-90

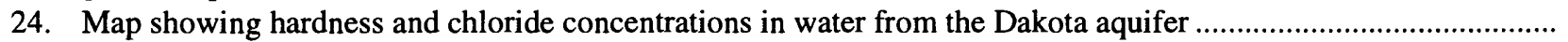

25. South Dakota irrigation-water classification diagram.....

26. Map showing water-level changes in the Tulare and other glacial aquifers between spring 1982 and spring 1990

\section{TABLES}

1. Generalized stratigraphic column showing geologic units and some of their characteristics

2. Estimated average annual water budget for surface-water and glacial-aquifer systems

3. Information pertaining to selected streamflow-gaging stations operated by the U.S. Geological Survey on the James River between Columbia and Huron and on tributaries in Spink County and adjacent counties.

4. Summary of lake data.....

5. Summary of chemical analyses of water in lakes in Spink County, in the James River at Ashton and Huron, in Snake Creek, and in precipitation.

6. Summary of the characteristics of major aquifers in Spink County

7. Summary of pumping tests of the Tulare aquifer

8. Summary of chemical analyses of ground water, 1937-91 


\section{TABLES-Continued}

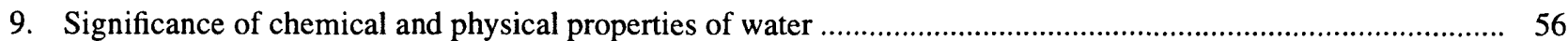

10. Estimated withdrawal of ground water in 1990

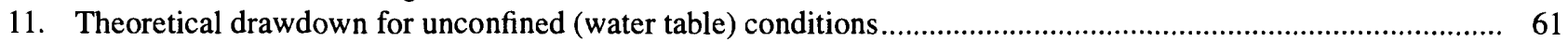

12. Theoretical drawdown for confined (artesian) conditions .........................................................................

\section{CONVERSION FACTORS AND VERTICAL DATUM}

\begin{tabular}{|c|c|c|}
\hline Multiply & By & To obtain \\
\hline acre & 4,047 & square meter \\
\hline acre & 0.4047 & hectares \\
\hline acre-foot & 1,233 & cubic meter \\
\hline acre-foot & 0.001233 & cubic hectometer \\
\hline acre-foot per year & 1,233 & cubic meter per year \\
\hline cubic foot & 0.02832 & cubic meter \\
\hline cubic foot per second & 0.02832 & cubic meter per second \\
\hline foot & 0.3048 & meter \\
\hline foot per day & 0.3048 & meter per day \\
\hline foot per mile & 0.1894 & meter per kilometer \\
\hline foot per month & 0.3048 & meter per month \\
\hline foot per year & 0.3048 & meter per year \\
\hline gallon per minute & 0.06308 & liter per second \\
\hline inch & 25.4 & millimeter \\
\hline inch per year & 25.4 & millimeter per year \\
\hline mile & 1.609 & kilometer \\
\hline million acre-feet & 1,233 & cubic hectometer \\
\hline million gallons per day & 0.0438 & cubic meter per second \\
\hline pound per square inch & 6.895 & kilopascal \\
\hline square foot & 0.0929 & square meter \\
\hline square foot per day & 0.0929 & square meter per day \\
\hline square mile & 2.590 & square kilometer \\
\hline ton & 907.2 & kilogram \\
\hline ton per square mile & 350.3 & kilogram per square kilometer \\
\hline
\end{tabular}

Temperature can be converted to degrees Fahrenheit $\left({ }^{\circ} \mathrm{F}\right)$ or degrees Celsius $\left({ }^{\circ} \mathrm{C}\right)$ by the following equations:

$$
\begin{aligned}
& { }^{\circ} \mathrm{F}=\frac{9}{5}\left({ }^{\circ} \mathrm{C}\right)+32 \\
& { }^{\circ} \mathrm{C}=\frac{5}{9}\left({ }^{\circ} \mathrm{F}-32\right)
\end{aligned}
$$

Sea level: In this report, "sea level" refers to the National Geodetic Vertical Datum of 1929_a geodetic datum derived from a general adjustment of the first-order level nets of the United States and Canada, formerly called Sea Level Datum of 1929. 


\title{
WATER RESOURCES OF SPINK COUNTY, SOUTH DAKOTA
}

\author{
By Louis J. Hamilton and Lewis W. Howells
}

\section{ABSTRACT}

Spink County, an agricultural area of about 1,505 square miles, is in the flat to gently rolling James River lowland of east-central South Dakota. The water resources are characterized by the highly variable flows of the James River and its tributaries and by aquifers both in glacial deposits of sand and gravel, and in sandstone in the bedrock. Glacial aquifers underlie about half of the county, and bedrock aquifers underlie most of the county.

The James River is an intermittent prairie stream that drains nearly 8,900 square miles north of Spink County and has an average annual discharge of about 124 cubic feet per second where it enters the county. The discharge is augmented by the flow of Snake and Turtle Creeks, each of which has an average annual flow of about 25 to 30 cubic feet per second. Streamflow is unreliable as a water supply because precipitation, which averages 18.5 inches annually, is erratic both in volume and in distribution, and because the average annual potential evapotranspiration rate is $\mathbf{4 3}$ inches. The flow of tributaries generally ceases by summer, and zero flows are common in the James River in fall and winter.

Aquifers in glacial drift deposits store nearly 3.3 million acre-feet of fresh to slightly saline water at depths of from near land surface to more than 500 feet below land surface beneath an area of about 760 square miles. Yields of properly developed wells in the more productive aquifers exceed 1,000 gallons per minute in some areas. Withdrawals from the aquifers, mostly for irrigation, totaled about 15,000 acre-feet of water in 1990. Water levels in observation wells generally have declined less than 15 feet over several decades of increasing pumpage for irrigation, but locally have declined nearly 30 feet. Water levels generally rose during the wet period of 1983-86.

In Spink County, bedrock aquifers store more than 40 million acre-feet of slightly to moderately saline water at depths of from 80 to about 1,300 feet below land surface. Yields of properly developed wells range from 2 to 600 gallons per minute. The artesian head of the heavily used Dakota aquifer has declined about 350 feet in the approximately 100 years since the first artesian wells were drilled in the county, but water levels have stabilized locally as a result of decreases in the discharge of water from the wells. Initial flows of from 4 gallons per minute to as much as 30 gallons per minute of very hard water can be obtained in the southwestern part of the county, where drillers report artesian heads of nearly 100 feet above land surface.

The quality of water from aquifers in glacial drift varies greatly, even within an aquifer. Concentrations of dissolved solids in samples ranged from 151 to 9,610 milligrams per liter, and hardness ranged from 84 to 3,700 milligrams per liter. Median concentrations of dissolved solids, sulfate, iron, and manganese in some glacial aquifers are near or exceed Secondary Maximum Contaminant Levels (SMCL's) established by the U.S. Environmental Protection Agency (EPA). Some of the water from aquifers in glacial drift is suitable for irrigation use. 
Water samples from aquifers in the bedrock contained concentrations of dissolved solids that ranged from 1,410 to 2,670 milligrams per liter (sum of constituents) and hardness that ranged from 10 to 1,400 milligrams per liter; these concentrations generally are largest for aquifers below the Dakota aquifer. Median concentrations of dissolved solids, sulfate, iron, and manganese in Dakota wells either are near or exceed EPA SMCL's. Dissolved solids, sodium, and boron concentrations in water from bedrock aquifers commonly are too large for the water to be suitable for irrigation use.

\section{INTRODUCTION}

A study to provide basic geologic and hydrologic data and water-quality analyses needed to evaluate the water resources of Spink County was conducted from 1987-92. Such information is necessary for efficient development of the water resources by agriculture, rural water systems, municipalities, and industry. This study was one of a series of evaluations of the water resources of counties in South Dakota (fig. 1). This study was accomplished by the U.S. Geological Survey in cooperation with the South Dakota Department of Environment and Natural Resources (DENR), Division of Geological Survey (hereinafter referred to as the South Dakota Geological Survey); Spink County; the James River Water Development District; and the Mid-Dakota Water Development District. Test drilling and studies of the geology and mineral resources were made concurrently by the South Dakota Geological Survey (SDGS). Information on construction of 90 observation wells and the water levels in those wells was supplied by the DENR, Division of Water Rights. The authors appreciate the cooperation of local residents, water superintendents, and well drillers for information on wells, well construction, and water yields.

Spink County, which has an area of about 1,505 square miles, is in the James River lowland of the Central Lowlands physiographic province (fig. 1). The county includes about 800 square miles of the Lake Dakota plain, the former bed of an ancient glacial lake, in a north-south band in the middle of the county, that is flanked by low, undulating hills. Agriculture is the primary industry for the population of nearly 9,000 people. About three-fourths of the county is cropland and most of the remainder is pasture and wetland. Although the average annual precipitation is about 18.5 inches, and the 5-month growing-season precipitation averages about 13 inches, almost all of the precipitation is consumed by evapotranspiration. The agricultural economy has been stabilized somewhat during drought by irrigation using water from the James River and from aquifers. The flow of the river is not dependable, however, and some of the aquifers have had large declines in water levels that locally reduce well yields. Prior to this study, little information was available on the extent and possible yields of aquifers in the glacial drift in the county.

\section{Purpose and Scope}

The purpose of this report is to describe the following: (1) The availability of water in streams, lakes, and aquifers; (2) the operation of the hydrologic system as it influences the availability of water; (3) the quality of water; and (4) the affects on the hydrologic system of development of the water resources. Current and potential water-use problems also are discussed.

\section{Methods of Investigation}

Existing streamflow data from the U.S. Geological Survey's National Water Data Storage and Retrieval System (WATSTORE), retrieved as computer-printed tables and statistical analyses, were used to help evaluate surface-water resources. Geohydrologic data from about 1,400 wells and 800 test holes were analyzed to determine the extent, thickness, yield, and water quality of aquifers. The locations of selected wells and test holes used for this study are shown in figure 2 . Electric logs were made of approximately 200 test holes that were drilled to bedrock. Water levels were measured monthly to bimonthly in a network of 200 observation wells installed in test holes drilled by the SDGS. Water levels in the observation-well network operated by the DENR were measured four to six times each year by DENR personnel. 


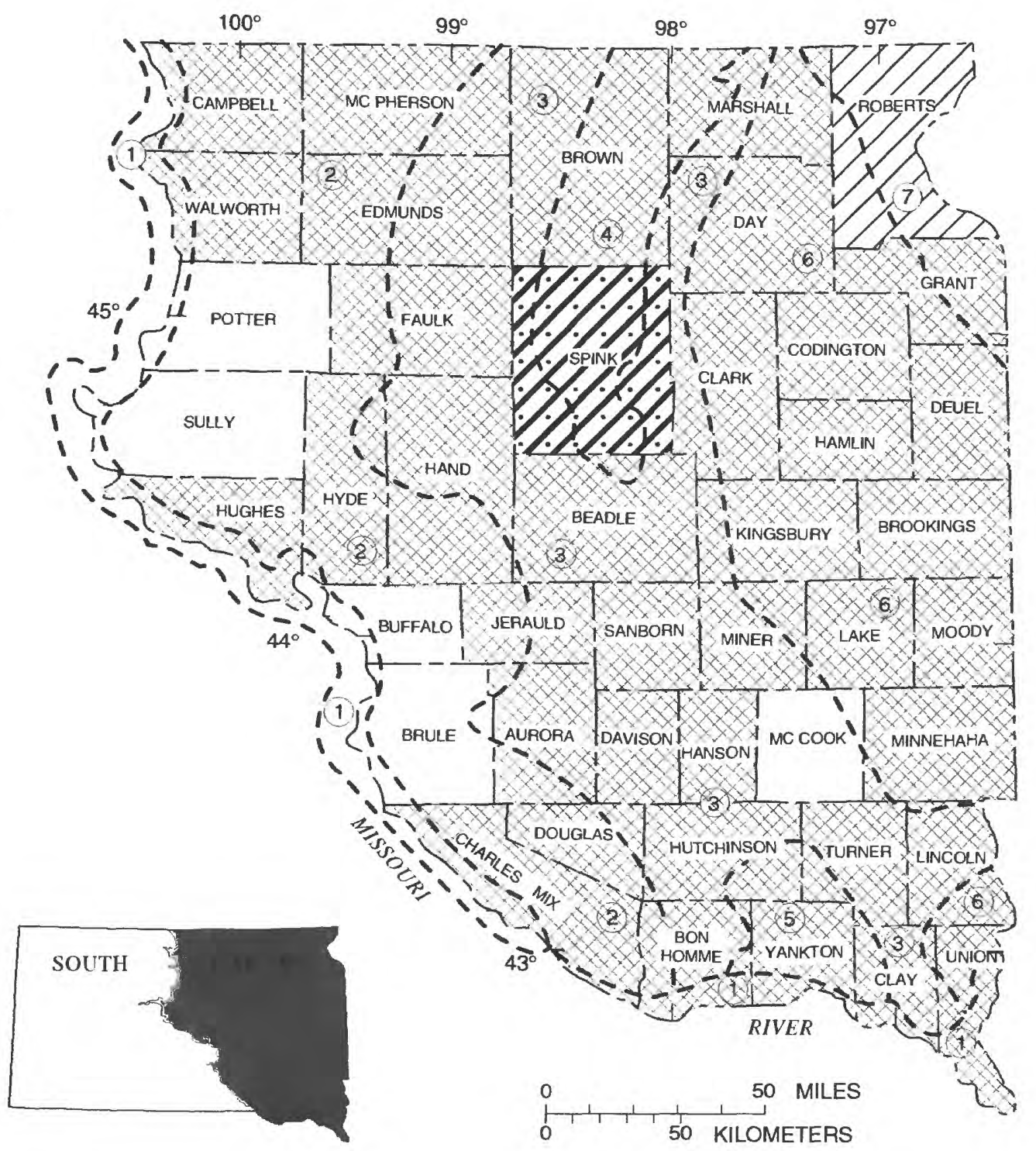

EXPLANATION

\begin{tabular}{|c|c|c|c|}
\hline \multicolumn{4}{|c|}{ Len erom } \\
\hline & STUDY AREA & & GREAT PLAINS PROVINCE \\
\hline & & (1) & Missouri River trench \\
\hline & INVESTIGATION IN PROGRESS & (2) & Coteau du Missouri \\
\hline & & & CENTRAL LOWLANDS PROVINCE \\
\hline & INVESTIGATION COMPLETED AND & (3) & James River lowland \\
\hline & REPORTS PUBLISHED OR IN PRESS & (4) & Lake Dakota plain \\
\hline & INVESTIGATION NOT SCHEDULED & (5) & James River highland \\
\hline & & (6) & Coteau des Praines \\
\hline & PHYSIOGRAPHIC BOUNDARY & (7) & Minnesota River-Red River lowlands \\
\hline
\end{tabular}

Figure 1. Index map of eastern South Dakota showing location of Spink County, status of county investigations, and locations of major physiographic divisions (physiographic divisions from Flint, 1955). 


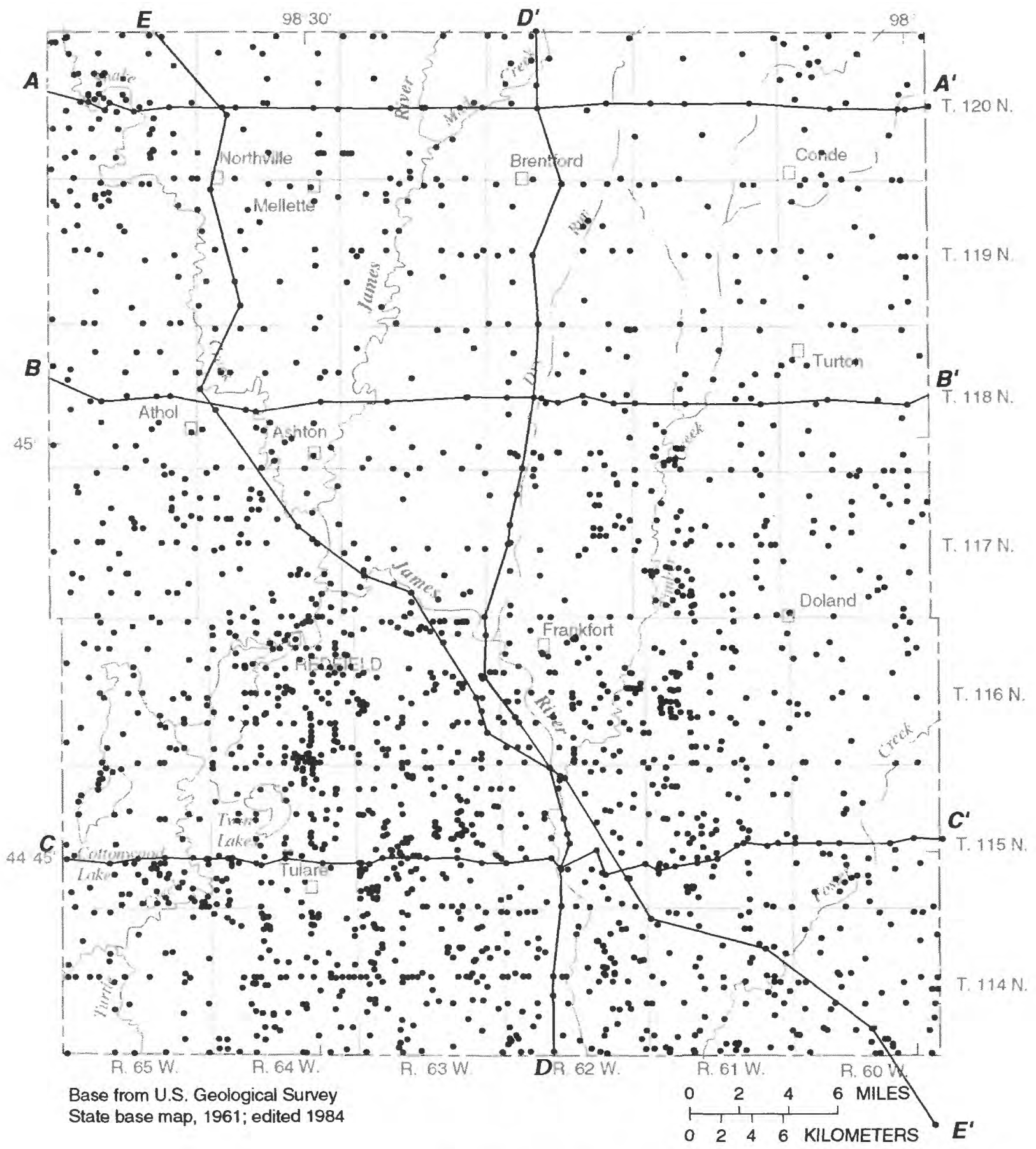

\section{EXPLANATION}

A — A LINE OF GEOLOGIC SECTION

WELL OR TEST HOLE--Aquifer description and drillers logs are available from U.S. Geological Survey

Figure 2. Locations of selected wells, test holes, and geologic sections in Spink County. 
Samples of water were collected from about 600 wells for field tests of specific conductance, hardness, and concentrations of bicarbonate and chloride. About 100 water samples were collected from representative wells for laboratory chemical analyses for the major constituents and for selected minor and trace elements commonly found in ground water. Wells, test holes, and water-sampling sites are numbered according to the Federal land-survey system for eastern South Dakota (fig. 3).

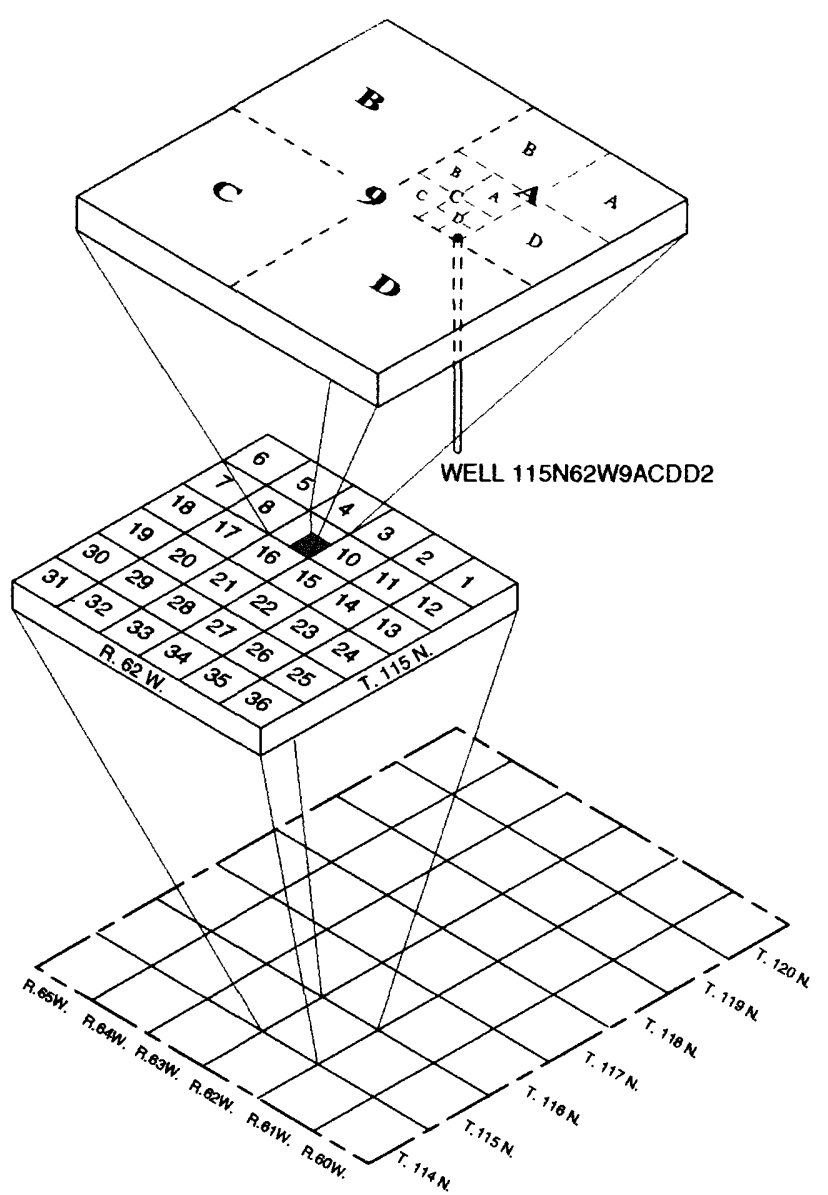

Figure 3. Well-numbering system. The well number consists of the township number, followed by "N," the range number followed by "W," and the section number, followed by a maximum of four uppercase letters that indicate, respectively, the 160-, 40-, 10-, and $21 / 2$-acre tract in which the well is located. These letters are assigned in a counter-clockwise direction beginning with " $A$ " in the northeast quarter. A serial number following the last letter is used to distinguish between wells in the same $21 / 2$-acre tract.

\section{Geology}

As a result of several episodes of continental glaciation in eastern South Dakota, 50 to 100 feet of glacial drift covers the bedrock in much of Spink
County. Where thickest, glacial drift is at least 500 feet thick. The largest known thicknesses of the major types of glacial deposits in Spink County are: at least 300 feet of clayey till; 200 feet of silty, clayey lake deposits; and 210 feet of outwash silt, sand, and gravel deposits. The clayey deposits are relatively impermeable, but the sand and gravel deposits are permeable and can yield as much as 1,200 gallons per minute of water to a properly constructed well.

Mapping of aquifers in glacial drift in eastern South Dakota can be difficult because deposits of permeable material commonly are discontinuous and because the depositional history of drift can be complex. Not only was the area invaded by major continental ice sheets several times, but fluctuation of the glacier margins during each of the invasion episodes eroded or deposited material beneath the ice. In addition, outflowing meltwater beneath the glacier, and along or in front of the ice margin, alternately eroded or deposited outwash. Thus, frequent periods of deposition of outwash within broad valleys alternated with periods of erosion by meltwater streams or by glacial ice. Previously deposited outwash, and other glacial materials, were eroded and redeposited on lower terraces or in steep-sided trenches that were cut into bedrock, or the materials were removed from the county.

As the last ice sheet to invade the area retreated, the central part of what is now Spink County was covered by a glacial lake whose southern end was near the Beadle County line and whose northern end was in North Dakota. This lake, named Lake Dakota, was about 30 miles wide and, at its maximum extent, more than 100 miles long (Flint, 1955, p. 126). A blanket of as much as 80 feet of silty, sandy, lake clay was deposited over till and outwash in the short-lived lake. As lake water overtopped the damming moraine and flowed southward, it rapidly eroded the trench of the present James River. The trench is about one-half mile wide and as much as 60 feet deep through Spink County.

The bedrock surface is the boundary between the bedrock formations and the overlying unconsolidated, glacial drift deposits. The shape of the bedrock surface (see fig. 4) influenced, at least in part, the location, texture, and thickness of permeable deposits in the drift, as well as locations of possible physical and hydraulic contact between aquifers in the glacial drift and aquifers in the bedrock. Although this map is based on data from logs of more than 1,400 test holes 


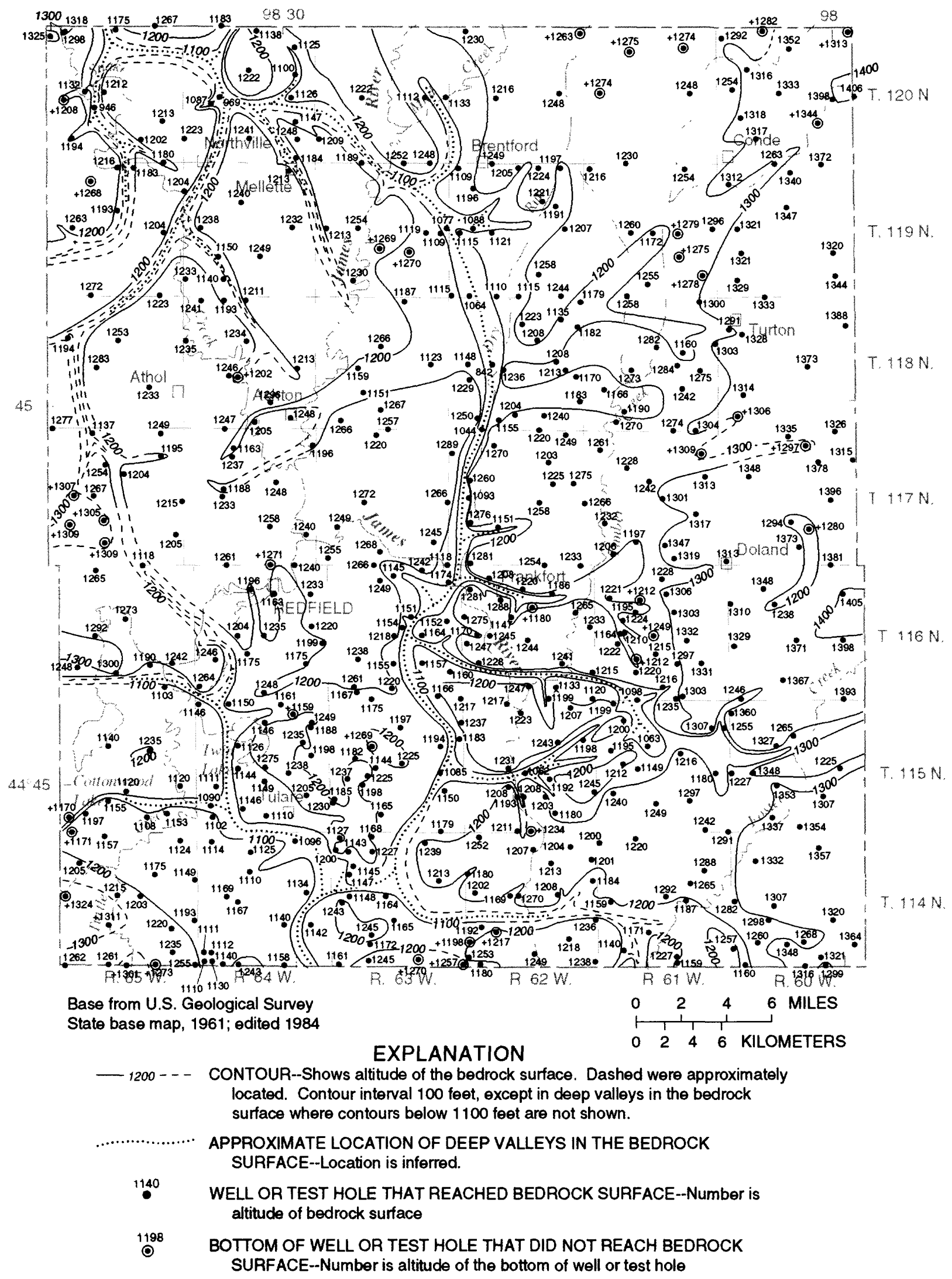

Figure 4. Topography of the bedrock surface and locations of selected wells and test holes (modified from D. Tomhave, South Dakota Geological Survey, written commun., 1995). 
and private water wells, it is nevertheless somewhat speculative; the exact locations of the deepest valleys in the bedrock surface are inferred because only one log in Spink County (118N62W17DDDD2) was of a well that reached bedrock below an altitude of 850 feet.

Glacial drift is underlain by an estimated 300 feet to more than 1,000 feet of bedrock formations of the Cretaceous, Jurassic, Permian, and Pennsylvanian Systems (table 1) in Spink County. Most of the rocks above the Dakota Sandstone are nearly impermeable shale that yields little or no water to wells. However, the highly calcareous Niobrara Formation, at depths to the top of the aquifer ranging from about 80 to 450 feet, contains a permeable interval that yields water to wells. The Dakota Sandstone, at depths to the top of the aquifer ranging from about 740 to 1,000 feet, is an extensive aquifer that supplies more than 250 flowing and nonflowing wells in Spink County. The Inyan Kara Group and Sundance Formation, composed of interbedded sandstone, siltstone, and shale, and the Minnelusa Formation, mostly sandstone, underlie the Dakota Sandstone in the western part of the county and supply a few flowing wells. These rocks are underlain by Precambrian metamorphic and igneous rocks that are impermeable except where fractured.

\section{Hydrology}

All water in Spink County is derived ultimately from precipitation, which supplies water for runoff to streams and for ground-water recharge. Large annual and seasonal fluctuations in precipitation, streamflow, and evapotranspiration are common.

Annual precipitation averages 18.5 inches, 70 percent of which falls during the 5-month growing season. Droughts lasting more than a year, during which precipitation is $\mathbf{5}$ or more inches less than normal, have a recurrence interval of 10 to 25 years (U.S. Geological Survey, 1991, p. 502). A 10-year recurrence interval means that an event has a 10 -percent chance of occurrence in any year; likewise, a 25-year recurrence interval infers a 4-percent chance of occurrence in any year.

Peak discharges on the James River having recurrence intervals of greater than 10 years occurred four times at Ashton and five times at Redfield between 1950 and 1992. Snake Creek inflow during large runoff events from snowmelt and spring rain can occasionally cause a temporary reverse flow in the flat, sluggish James River. However, many days of zero flow are common in most years, usually during late summer, fall, and winter.

Snowmelt and spring precipitation that does not run off to streams may accumulate in numerous shallow depressions within the county and may recharge ground water. However, most of this water is lost to natural evapotranspiration during the summer, partly because the water table ranges from near land surface to 30 feet below land surface. Large pumpage of irrigation wells can, however, lower the water table and decrease natural evapotranspiration from the ground-water reservoirs.

The estimated water budget for the county, which assumes long-term average, steady-state conditions, is dominated by precipitation and by evapotranspiration (table 2). About 90 percent of the water entering the county $(1,485,000$ acre-feet) occurs as precipitation. Streamflow in and streamflow out of the county, mostly through the James River, accounts for nearly 10 percent of the budget. Ground-water inflow, mostly to aquifers in the southwestern part of the county, accounts for less than 2 percent. Groundwater outflow accounts for less than one-half of 1 percent. Evapotranspiration, estimated as the difference between water in and water out, accounts for about 90 percent of the water budget.

\section{SURFACE WATER}

\section{Streams}

All streams in Spink County are part of the James River drainage system (fig. 5). The James River is a meandering, low-gradient, slow-flowing, intermittent prairie stream that flows southward in North and South Dakota to the Missouri River near Yankton, South Dakota. The river has about 750 miles of channel to cross a straight-line distance of about 380 miles. Where the James River enters Spink County (station 06472000), its average annual rate of flow is about 124 cubic feet per second (about 89,800 acre-feet of water per year) from a drainage area of 8,865 square miles, about 45 percent of which is noncontributing. Within Spink County, the James River has about 95 miles of channel crossing a straight-line distance of 43 miles. 


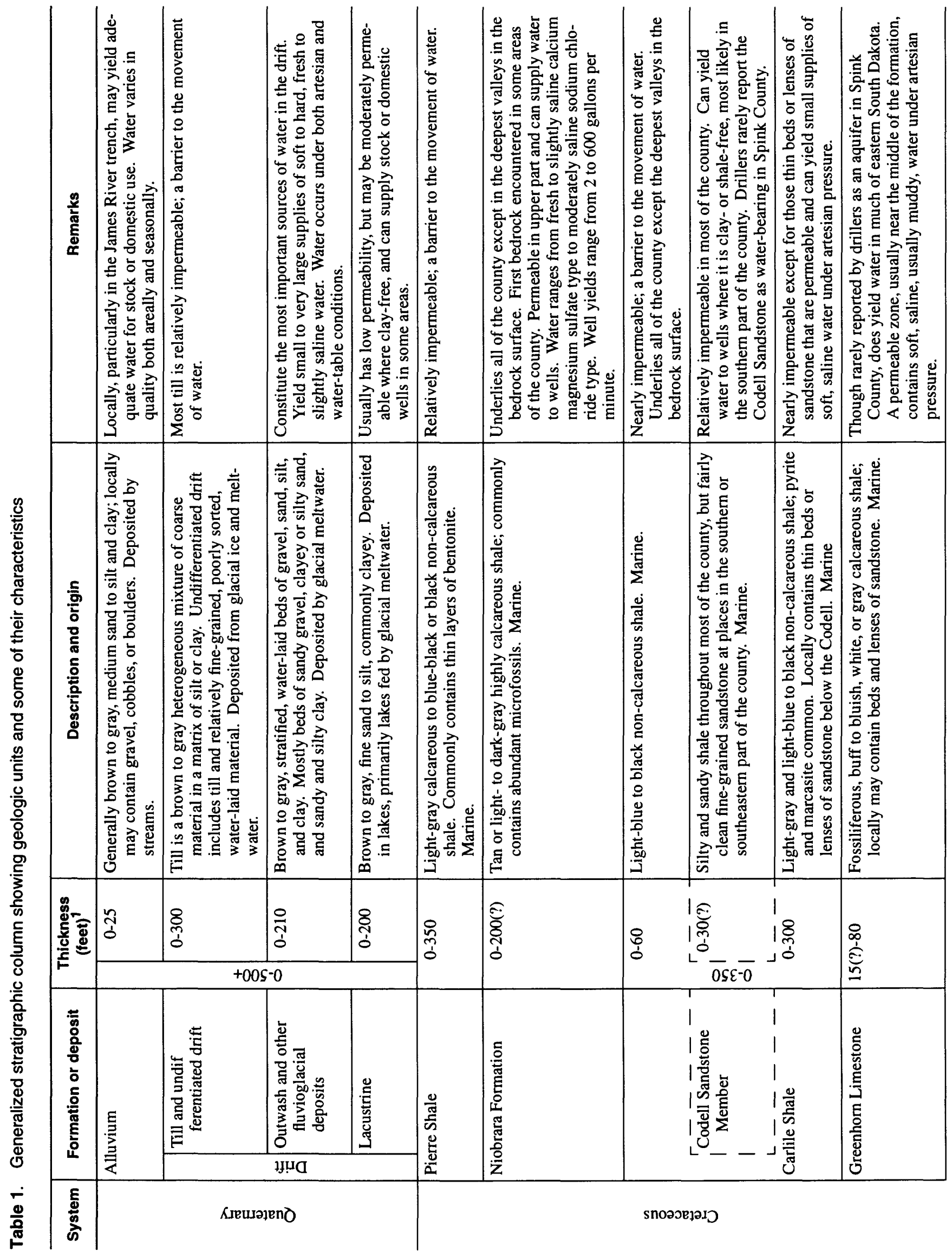

8 Water Resources of Spink County, South Dakota 


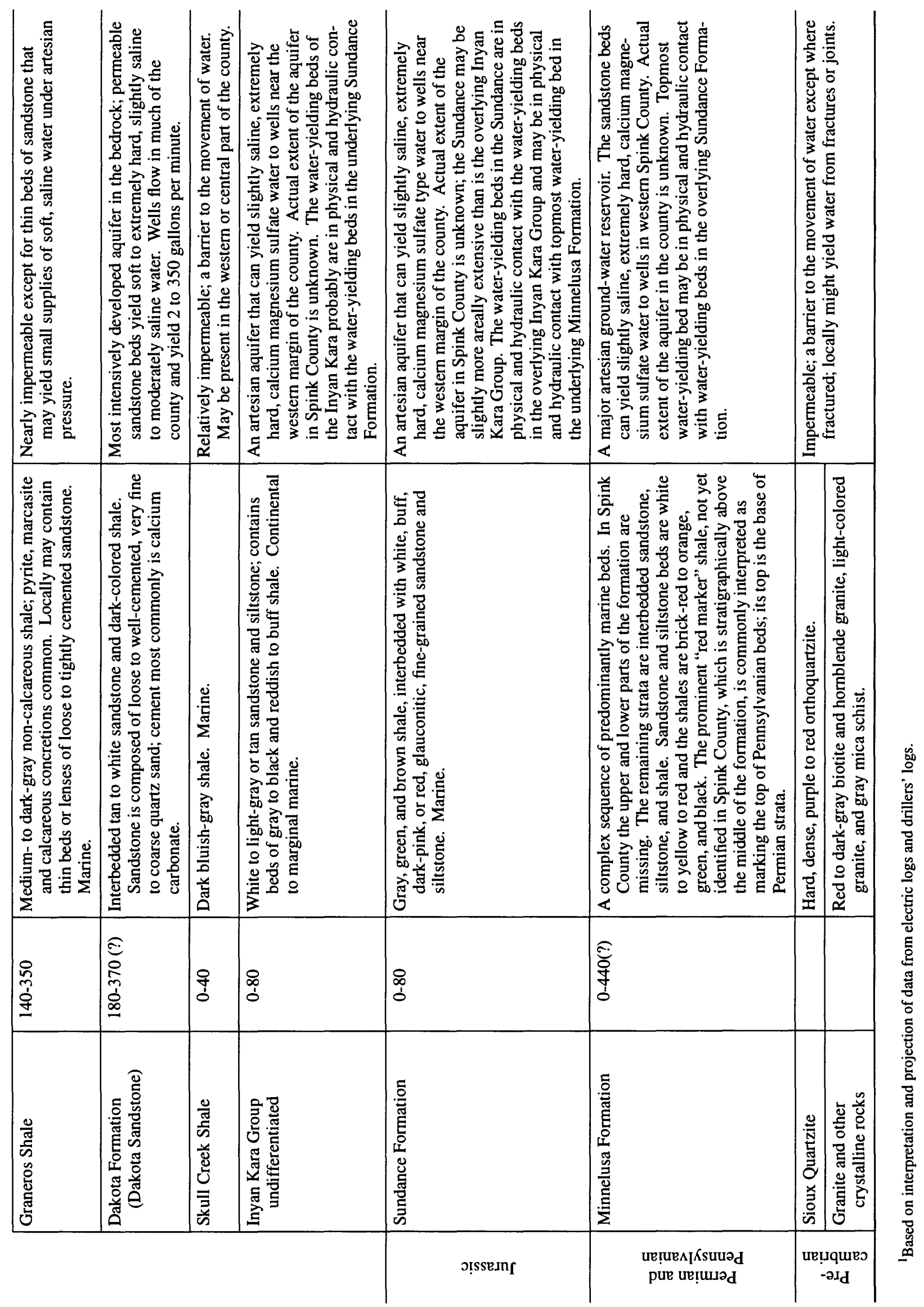


Table 2. Estimated average annual water budget for surface-water and glacial-aquifer systems

[All units in acre-feet, except as noted]

\begin{tabular}{|c|c|c|c|c|c|c|c|c|c|c|c|}
\hline & \multicolumn{7}{|c|}{ Surface water } & \multicolumn{2}{|c|}{ Ground water } & \multicolumn{2}{|c|}{ Total $^{1}$} \\
\hline & $\begin{array}{l}\text { James } \\
\text { River }\end{array}$ & $\begin{array}{l}\text { Snake } \\
\text { Creek }\end{array}$ & $\begin{array}{l}\text { Turtle } \\
\text { Creek }\end{array}$ & $\begin{array}{l}\text { Mud } \\
\text { Creek }\end{array}$ & $\begin{array}{l}\text { Dry } \\
\text { Run }\end{array}$ & $\begin{array}{l}\text { Timber } \\
\text { Creek }\end{array}$ & $\begin{array}{l}\text { Foster } \\
\text { Creek }\end{array}$ & $\begin{array}{l}\text { Inflow } \\
\text { from } \\
\text { west }\end{array}$ & $\begin{array}{l}\text { Inflow } \\
\text { from } \\
\text { east }\end{array}$ & (acre-feet) & (inches) \\
\hline Precipitation & & & & & & & & & & $1,485,000$ & (18.5) \\
\hline Streamflow & 89,800 & 14,500 & 10,800 & 6,500 & 300 & 400 & 1,000 & & & 123,300 & (1.5) \\
\hline $\begin{array}{l}\text { Discharge of flowing } \\
\text { bedrock wells }\end{array}$ & & & & & & & & & & ${ }^{2} 5,800$ & $(0.1)$ \\
\hline Total & & & & & & & & & & $1,634,000$ & $(20.4)$ \\
\hline \multicolumn{12}{|l|}{ Water out: } \\
\hline Evapotranspiration & & & & & & & & & & $1,469,000$ & $(18.3)$ \\
\hline Total & & & & & & & & & & $1,634,000$ & $(20.4)$ \\
\hline
\end{tabular}

${ }^{1}$ Totals rounded, therefore may not exactly balance.

${ }^{2}$ Included because it is an input to the surface-water/glacial-aquifer system.

${ }^{3}$ Estimated to have been about 20,000 acre-feet prior to the use of ground water for irrigation in the southwestern part of the county.

The James River is the major stream in the county; however, it has no flow during late summer, fall, and winter in many years, as well as more extended periods of no flow during major droughts. The river is, nevertheless, important as a source of water for municipalities, irrigation, livestock, recreation, and wildlife. The average annual flow of the James River was fully appropriated for beneficial use by 1967 . There is more than 400,000 acre-feet of storage in eight reservoirs upstream from Spink County, but little or none of the stored water is available for use during drought.

Streams tributary to the James River that flow through Spink County are Snake, Turtle, Wolf, Medicine, Timber, Mud, and Foster Creeks and Dry Run. All of these streams are ephemeral-that is, they flow only in direct response to precipitation or snowmelt. Except for Dry Run, all of these streams contain segments where the stream channel is below the local water table and, therefore, the streams contain pools of water that are more or less permanent. Streamflow information for selected gaging stations between Columbia and Huron are given in table 3.

An estimated 8 percent of Spink County is drained internally; that is, these areas do not contribute surface runoff to the flow of major tributaries or of the James River. In addition, many other minor water courses usually carry internal drainage water during the spring snowmelt or after heavy rains, but may contribute to the James River or its tributaries every few years during extended periods of much greater than normal precipitation. Such water courses may have little topographic expression; some of them may be recognizable as drainageways only when they are conveying water.

Potential evapotranspiration losses from Spink County are high - the average annual loss from openwater surfaces (lakes, ponds, streams, and bogs) is estimated by Farnsworth and others (1982) to be 43 inches, which is about two and one-third times the average annual precipitation of 18.5 inches (calculated from National Weather Service data by the polygonof-influence method). These losses greatly reduce streamflow in summer (fig. 6).

Ground-water discharge to surface streams in Spink County is minimal; it is not sufficient to sustain streamflow during most years. Losses to evapotranspiration and lack of significant ground-water discharge to surface streams is further illustrated in figure 6-one-third of average annual precipitation occurs during the three months of July, August, and September, but less than one-fourth of annual streamflow occurs then. 


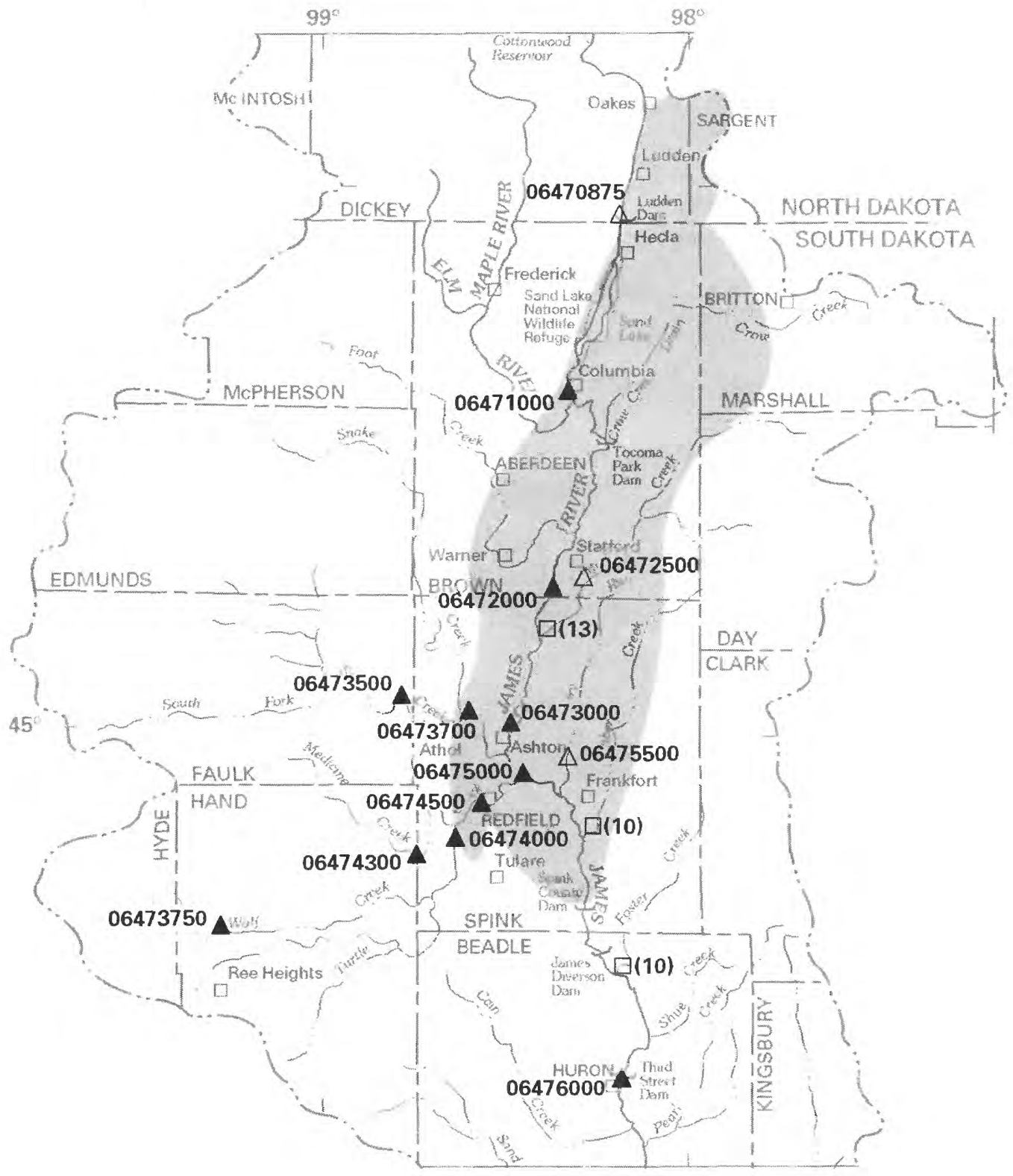

\section{EXPLANATION}

LAKE DAKOTA PLAIN

06471000

STREAMFLOW-GAGING STATION--

Period of record more than 15

years. Number is station

identification number.

06475500

$\triangle$ STREAMFLOW-GAGING STATION--

Period of record less than 15

years. Number is station

identification number.
(10) $\square$ STREAMFLOW ESTIMATION SITE--

Number in parentheses is estimated flow, in cubic feet per second, using the method by Lanimer (1970), except a regression coefficient of $9 \times 10^{-7}$ was used to get a closer agreement with flows at 4 gaging stations on nearby streams.

JAMES RIVER BASIN BOUNDARY

Figure 5. Average streamflow, middle James River Basin, and locations of selected streamflow-gaging stations, North and South Dakota (Benson, 1988; Wiche and others, 1989). 


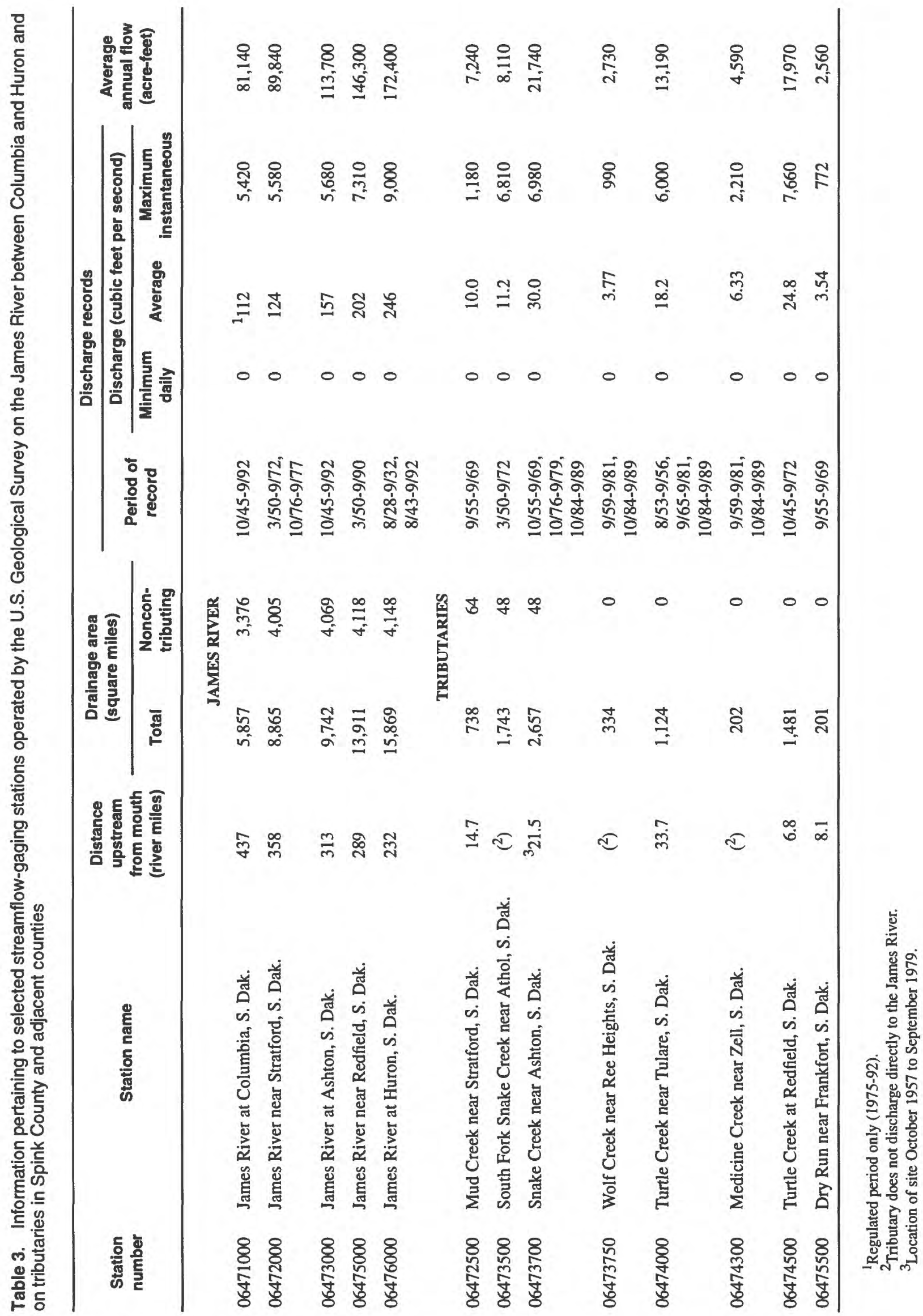




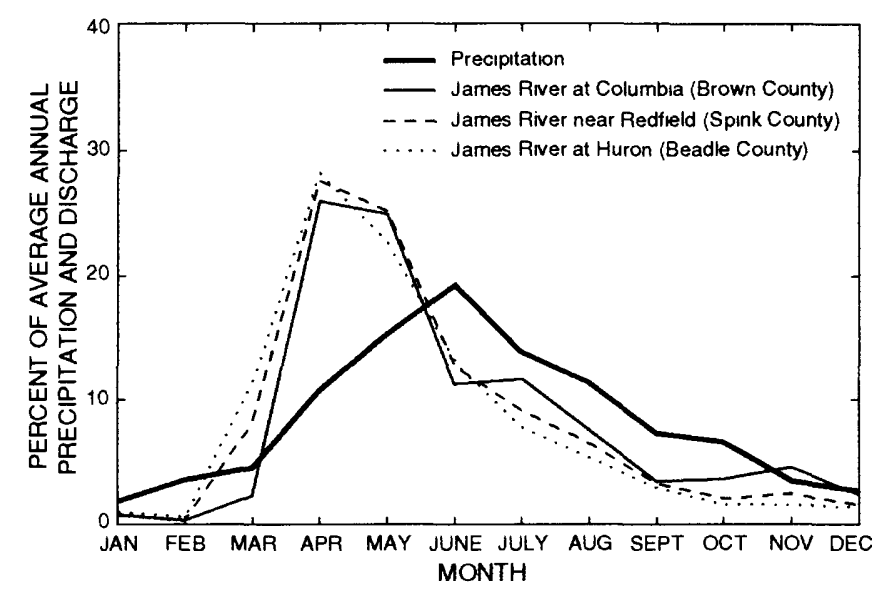

Figure 6. Monthly distribution of average annual precipitation in Spink County and of annual discharge of the James River at three locations.

The annual discharge of the James River within and downstream of Spink County exhibits large fluctuations (fig. 7). At Ashton, the annual discharge of the James River is 113,700 acre-feet ( 157 cubic feet per second). During the 42-year period of 1951-92, the annual discharge was less than 50,000 acre-feet (69 cubic feet per second) for 18 years and was greater than 200,000 acre-feet ( 276 cubic feet per second) for 9 years. Similar large fluctuations in annual discharge occur at the downstream gages near Redfield and at Huron. The gains and losses between the Ashton, Redfield, and Huron gages also are shown in figure 7. For instance, during 1969 the annual discharge was 462,800 acre-feet at Ashton, 652,500 acre-feet near Redfield, and 731,000 acre-feet at Huron. Thus, the Ashton-to-Redfield gain was 189,700 acre-feet and the Redfield-to-Huron gain was 78,500 acre-feet. Conversely, during 1974 the annual discharge was 29,460 acre-feet at Ashton, 27,890 acre-feet near Redfield, and 22,660 acre-feet at Huron. Thus, the Ashton-to-Redfield loss was 1,570 acre-feet and the Redfield-to-Huron loss was 5,230 acre-feet.

\section{Flow Duration}

Duration hydrographs for the exceedance probability of daily mean discharge for the James River at Ashton (station 06473000 , fig. 5) show that discharge is largest during spring (fig. 8), when runoff of snowmelt and rainfall is largest. Discharge decreases gradually during late spring and summer as evapotranspiration increases, but then stabilizes in fall as temperatures cool and evapotranspiration decreases. Discharge is least in winter. Separate curves show the daily discharge for the maximum values and also for the 20-, 50-, and 80-percent exceedance values for the period 1952 through 1990. Minimum discharges for each day of the year are zero and are not shown because of the log scale used. Discharges for the 20-, 50-, and 80-percent curves can be expected to be equaled or exceeded 20,50 , and 80 percent of the time. For example, a discharge equal to or exceeding 200 cubic feet per second can be expected 50 percent of the time on any one day during the periods from April 18-27 and May 2-29. A similar duration hydrograph for the James River near Redfield (Benson, 1988, fig. 5), 14 miles further downstream, shows that a discharge equal to or exceeding 300 cubic feet per second can be expected 50 percent of the time on any one day during the period from April 18-27, on May 2, and during the period from May 14-31. The larger discharge is due mainly to inflow from two large tributaries, Snake Creek and Turtle Creek.

\section{Low Flow}

Low flows of less than 1 cubic foot per second are common for the James River during the fall and winter months, averaging 3 months per year at the gage near Redfield from 1970 to 1990 and lasting 6 months or more in 1973, 1977, 1981, and 1988-90. Zero flow conditions for as long as 590 consecutive days have occurred at the gage at Ashton (Aug. 14, 1958, to Mar. 25, 1960).

Streamflow measured on the James River for a seepage run on June 22 and 23, 1988, when there was no precipitation or inflow from tributaries, were 0.1 cubic foot per second at the discontinued gage near Stratford (Brown/Spink County line), 2.5 cubic feet per second 24 miles downstream from the Stratford gage, 3.6 cubic feet per second 21 miles farther downstream at the Ashton gage, and 5.5 cubic feet per second 19 miles farther downstream at the gage near Redfield. The slightly larger gain in discharge between Ashton and Redfield ( 0.10 cubic foot per second per mile), as compared to 0.08 cubic foot per second per mile for the Stratford-Ashton reach, probably was due to seepage from sewage lagoons, from bank storage, and catching up to a pulse of streamflow caused by a storm that dropped from 0.4 to 1.2 inches of rain from June 12-17.

Discharges of more than 20 cubic feet per second at Ashton generally occur only in spring; a 
discharge of 20 cubic feet per second has been equaled or exceeded 80 percent of the time from April 13 to May 17; May 21-23; May 27, 29, and 31; and June 1, 6-8, 27-28 (fig. 8). The 50-percent exceedance discharge (median) at Ashton is equal to or less than 10 cubic feet per second from August 29 through March 14, except for a short period in late fall (November 25 to December 3) when the median flow ranges from 10 to 18 cubic feet per second. Downstream 19 miles, at the gage near Redfield, the median flow is less than 10 cubic feet per second only from
January 6 through March 11 and from September 19 through November 23 (Benson, 1988, p. 18). No-flow conditions occur for longer periods on tributary streams because the smaller drainage areas result in more rapid runoff and because there is little groundwater discharge. To a much lesser extent, the no-flow periods are longer on tributaries because there are few reservoirs to regulate flow and because of loss of water to bank storage and evapotranspiration, and retention in stock ponds, dugouts, and a few irrigation-storage impoundments.

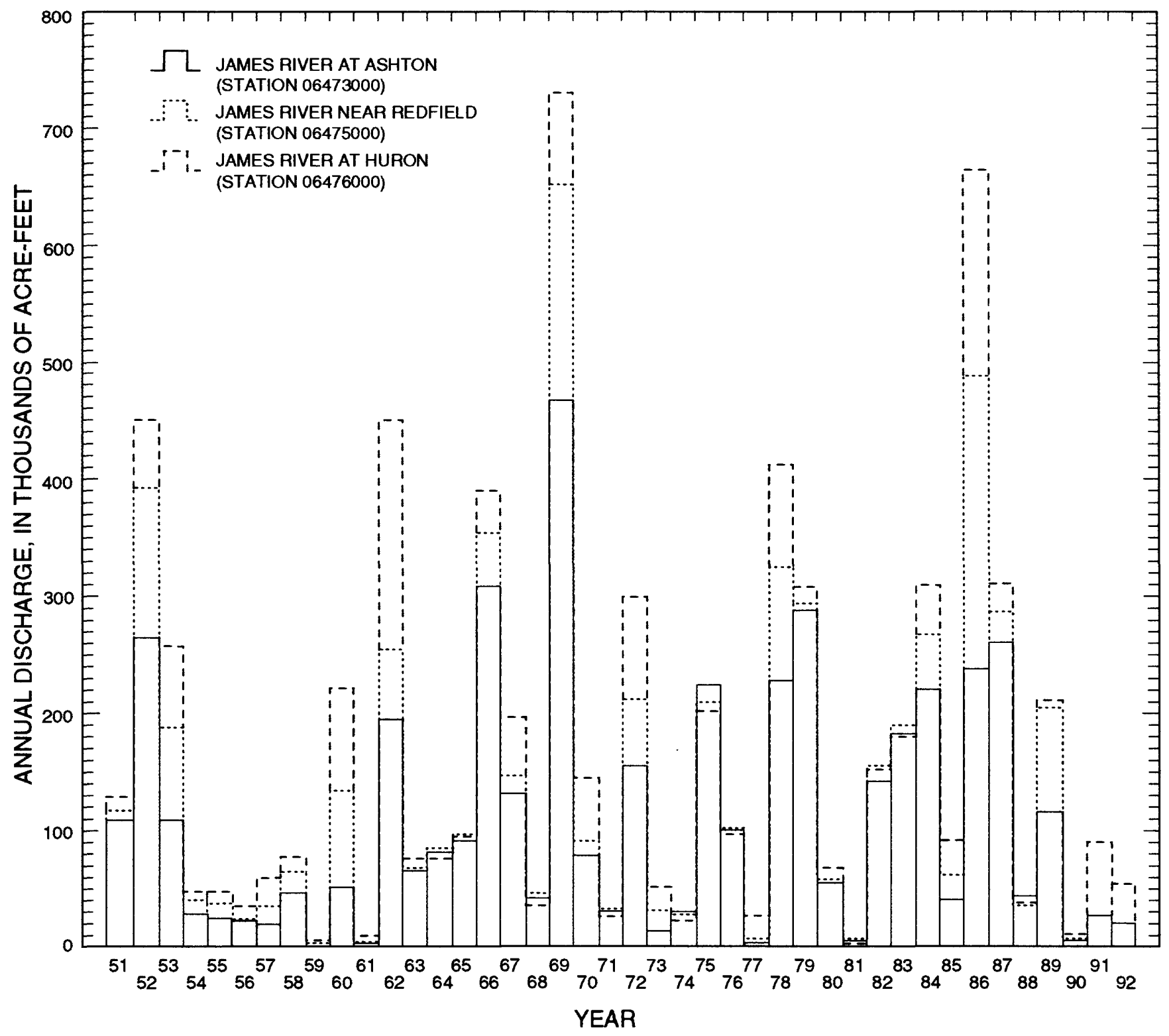

Figure 7. Annual discharge and gain or loss in flow along the James River between Ashton and Huron during water years 1951-92 (continuous streamflow measurement at Redfield was discontinued at the end of the 1990 water year). 


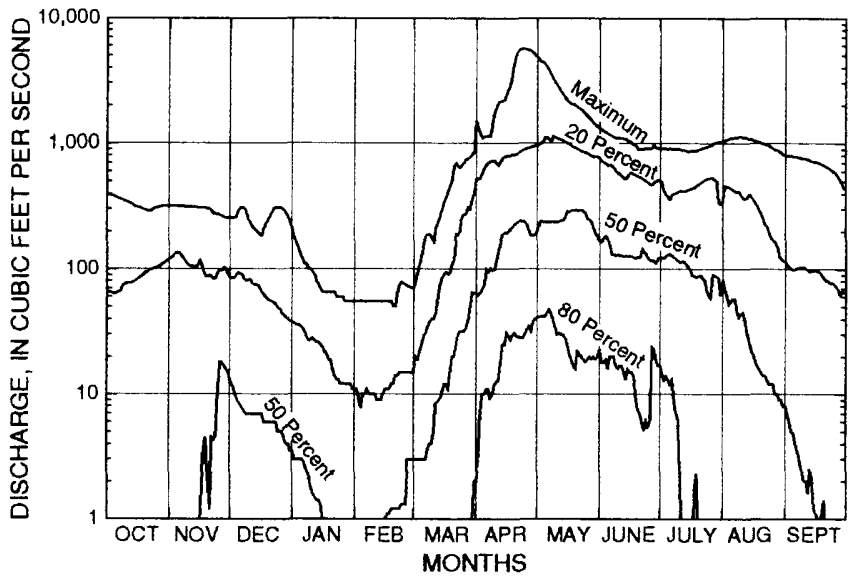

Figure 8. Duration hydrograph for daily discharges of the James River at Ashton, water years 1952-90.

\section{Floods}

Flooding from snowmelt and from rainfall in spring is common along the James River because of its large drainage area, low gradient, and relatively small channel capacity. Flooding of the river at Ashton begins when the bankfull flow capacity of about 1,000 cubic feet per second (Benson, 1983, p. 13) is exceeded. Peak flows that have a recurrence interval of 10 years (a 10-percent chance of being equaled or exceeded in any year) are 2,200 cubic feet per second at the gage at Ashton and 3,570 cubic feet per second 19 miles downstream at the gage near Redfield (U.S.
Geological Survey, unpub. data, 1992). A flood that has a recurrence interval of 100 years (a 1-percent chance of being equaled or exceeded in any year) would be about 11.5 feet above bankfull stage and have a peak flow of about 6,600 cubic feet per second at Ashton. A 100-year flood at the gage near Redfield would be 11 feet above bankfull stage and have a peak flow of about 9,780 cubic feet per second. Maps of flood-prone areas at a scale of about 2.64 inches to the mile can be obtained from the U.S. Geological Survey, Huron, South Dakota.

\section{Lakes and Wetlands}

Lakes and wetlands occupy about 1 percent of the county and provide important habitat for wildlife. Spink County contains six lakes that range in size from 30 to 1,530 acres that are classified as suitable for fish propagation (table 4). All six lakes are drainage lakes; that is, their levels are controlled by overflow through surface outlets. Cottonwood Lake is the largest in area, 1,530 acres (2.4 square miles), and has the second largest storage capacity $(6,500$ acrefeet). Twin Lakes, the second largest, has an area of 1,220 acres (1.9 square miles), and has the largest storage capacity $(9,000$ acre-feet). The narrow, 44-mile-long reservoir on the James River created by the James Diversion Dam in northern Beadle County

Table 4. Summary of lake data

$[--$, no information available $]$

\begin{tabular}{|c|c|c|c|c|c|c|}
\hline \multirow{2}{*}{ Lake name } & \multirow{2}{*}{ Location } & \multicolumn{2}{|c|}{ Depth (feet) } & \multirow{2}{*}{$\begin{array}{c}\text { Surface } \\
\text { area }^{1} \\
\text { (acres) }\end{array}$} & \multirow{2}{*}{$\begin{array}{l}\text { Storage } \\
\text { capacity } \\
\text { (acre-feet) }\end{array}$} & \multirow{2}{*}{$\begin{array}{c}\text { Classification } \\
\text { for } \\
\text { beneficial use }\end{array}$} \\
\hline & & Maximum ${ }^{1}$ & Average & & & \\
\hline Cottonwood & $115 \mathrm{~N} 65 \mathrm{~W} 4,5,7,8,9,17$ & 9 & 14.3 & 1,530 & 6,500 & 4 \\
\hline Twin & $115 \mathrm{~N} 64 \mathrm{~W} 8,9,10,15,16$ & 14 & 17.5 & 1,220 & 9,000 & 4 \\
\hline $\begin{array}{c}\text { James River above } \\
\text { diversion dam }\end{array}$ & $112 \mathrm{~N} 62 \mathrm{~W} 13$ & 9 & 5.5 & 1,100 & ${ }^{3} 6,000$ & 4 \\
\hline Redfield & 116N64W5,6,7,8,9 & -- & -- & 180 & -- & 4 \\
\hline Mirage & $\begin{array}{l}115 \text { N60W6,7 } \\
116 \text { N60W31 }\end{array}$ & 14 & ${ }^{1} 5.4$ & 140 & 750 & 4 \\
\hline Dudley & $114 \mathrm{~N} 62 \mathrm{~W} 21$ & 16 & $1_{10.0}$ & 30 & -- & 4 \\
\hline Total & & & & 4,200 & & \\
\hline
\end{tabular}

'From maps of South Dakota Department of Game, Fish and Parks.

${ }^{2}$ Classifications for beneficial use from South Dakota Water Quality Standards effective Feb. 19, 1981: 4, warm water permanent fish life propagation waters.

${ }^{3}$ From area-capacity rating curves of the U.S. Bureau of Reclamation. 
stores much of its 6,000 acre-feet of water in Spink County. There are more than 21,000 sloughs or potholes that have a combined area of about 55 square miles or 35,300 acres (Limmer and Fredrickson, 1975). Most of the wetlands are ephemeral ponds of less than 2 acres in size. The wetlands rarely are a source of recharge to ground water because the underlying material commonly is nearly impermeable and because potholes and sloughs rapidly lose water through evapotranspiration. Potholes and sloughs may remain dry for several consecutive years during drought.

\section{Water Quality}

The quality of surface water in Spink County, summarized in table 5, ranges from fair to very poor, depending on many factors, including the water source, time of year, and streamflows. The system of reservoirs in the James River Basin upstream from Spink County (total storage capacity about 425,000 acre-feet) does not seem to have any stabilizing effect on the average water quality in the James River. In fact, evapotranspiration losses from the reservoirs cause an increase in the average dissolvedsolids concentration and a decrease in overall quality in James River water.

Dissolved solids in lakes and streams in Spink County are mostly natural chemicals leached from soil by runoff. The dominant constituents are sodium, magnesium, bicarbonate, and sulfate. Subordinate constituents in surface water (such as suspended sediments, chloride, nitrate, phosphate, herbicides, and pesticides) include some pollutants from human activities that reach streams in runoff or by seepage from fields and pastures, landfills, sewage lagoons, septic tanks, roads, feedlots, and barnyards.

The quality of water in Spink County lakes depends on many factors, but the hydrologic setting of the particular lake and seasonal changes in precipitation and evaporation are important. Cottonwood Lake and Twin Lakes both are classified as drainage lakes in glacial till, but Cottonwood has a large surface inflow and, therefore, a lower dissolved-solids concentration than Twin Lakes (table 5). Inflow to Twin Lakes is mostly seepage of ground water plus some ephemeral surface runoff from its small tributary basin; many years Twin Lakes has no outflow. During 1965-66, the dissolved-solids concentration of water from Twin Lakes (4 samples) averaged $1,880 \mathrm{mg} / \mathrm{L}$ (milligrams per liter) and ranged from 1,630 to $2,100 \mathrm{mg} / \mathrm{L}$
(Schmidt, 1967, p. 94). From 1959 to 1964, the dissolved-solids concentration of water from Cottonwood Lake (27 samples) averaged $1,190 \mathrm{mg} / \mathrm{L}$ and ranged from 160 to $2,090 \mathrm{mg} / \mathrm{L}$ (Petri and Larson, no date, p. 47). Differences in the number of samples collected and timing of sampling make comparison of water-quality data for the two lakes difficult.

The dissolved-solids and suspended-sediment concentrations in water of the James River in Spink County vary widely with flow conditions. Dissolvedsolids concentration usually is highest during low flow under ice in winter and is lowest during high flow in spring. Dissolved-solids concentration for 14 years (1977-90) averaged $790 \mathrm{mg} / \mathrm{L}$ for 51 samples and ranged from 200 to $6,580 \mathrm{mg} / \mathrm{L}$ at the gaging station at Ashton (table 5). At Huron, concentrations of dissolved solids for 376 samples during 35 years of record averaged $746 \mathrm{mg} / \mathrm{L}$ and ranged from $150 \mathrm{mg} / \mathrm{L}$ to $1,900 \mathrm{mg} / \mathrm{L}$.

Monthly loads of dissolved solids carried by the James River were estimated from monthly mean dissolved-solids concentration as calculated from specific conductance by linear regression equations (Briel, 1989). Dissolved-solids load in the runoff from the 4,120 square miles of contributing drainage area between the Ashton and Redfield gaging stations, mainly from Snake and Turtle Creeks, was estimated to total 316,000 tons between 1974 and 1988 (fig. 9). Between the gaging stations near Redfield and at Huron, the dissolved-solids load was estimated to total 252,000 tons from 1,928 square miles of contributing drainage area. About 80 percent of the dissolvedsolids load in runoff came between 1984 and 1987 when precipitation was 8 to 22 inches above normal and when above-normal precipitation in the portion of the basin contributing to the Redfield-Huron reach was about double the above-normal precipitation in the portion of the basin contributing to the AshtonRedfield reach. Consequently, between 1984 and 1987, the load per unit area of dissolved solids from the lower basin was slightly less than double that of the upper basin, 105 tons per square mile compared to 61 tons per square mile. The probable cause of the larger load per unit area from the downstream basin is greater flushing of soluble material, including that which had accumulated in sloughs, pot holes, and other areas that do not drain to the James River in years of normal or less than normal precipitation. 


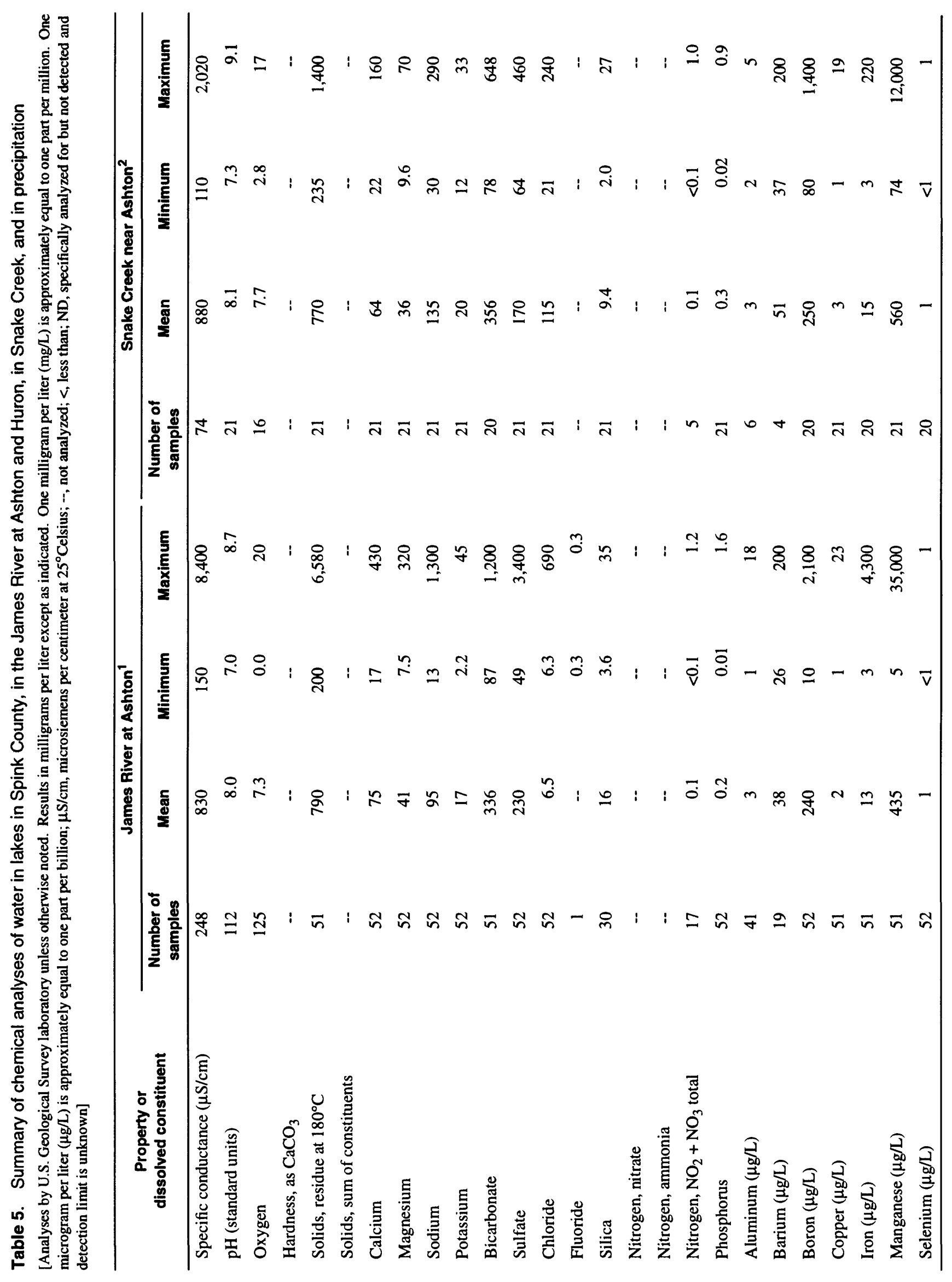




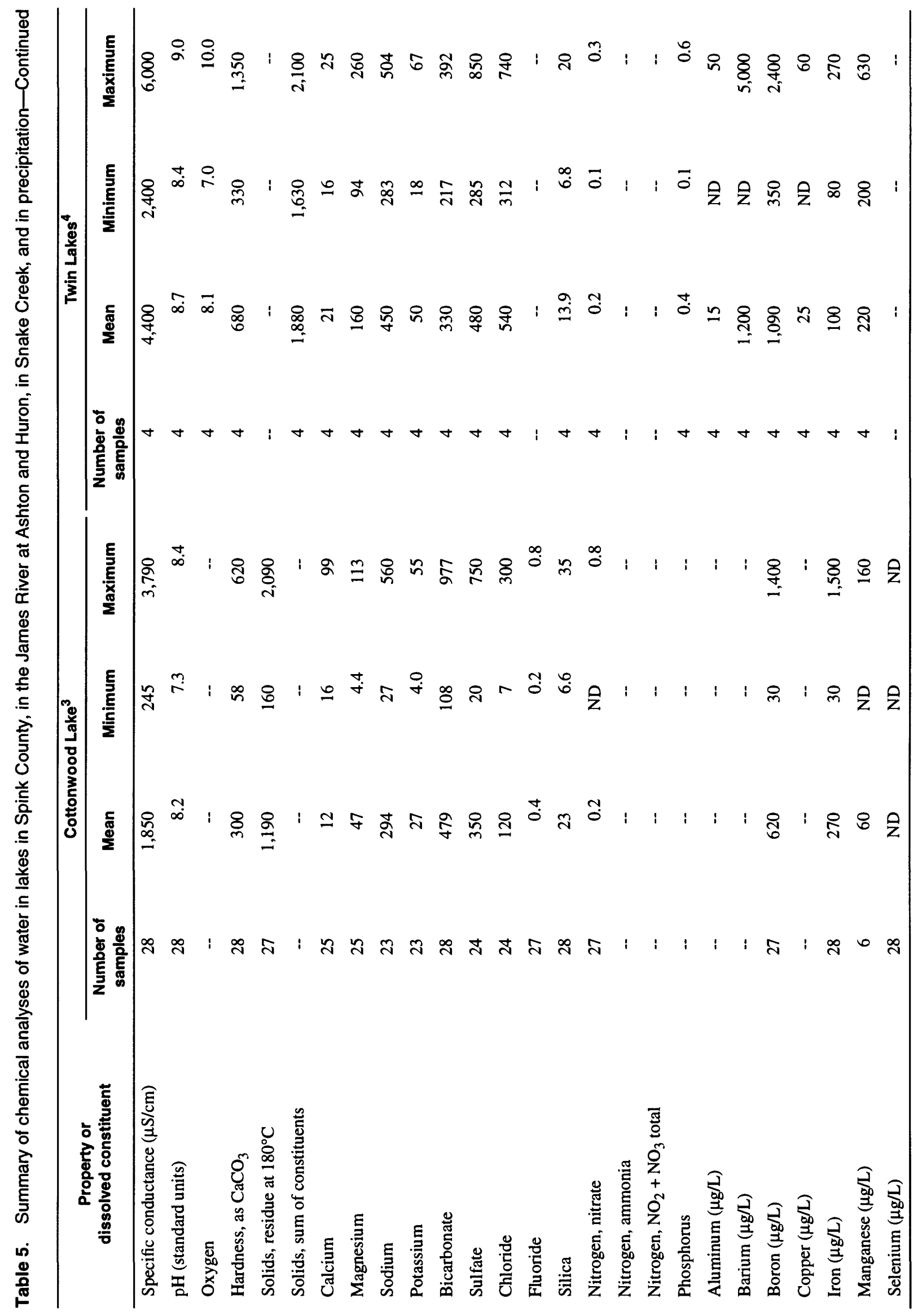




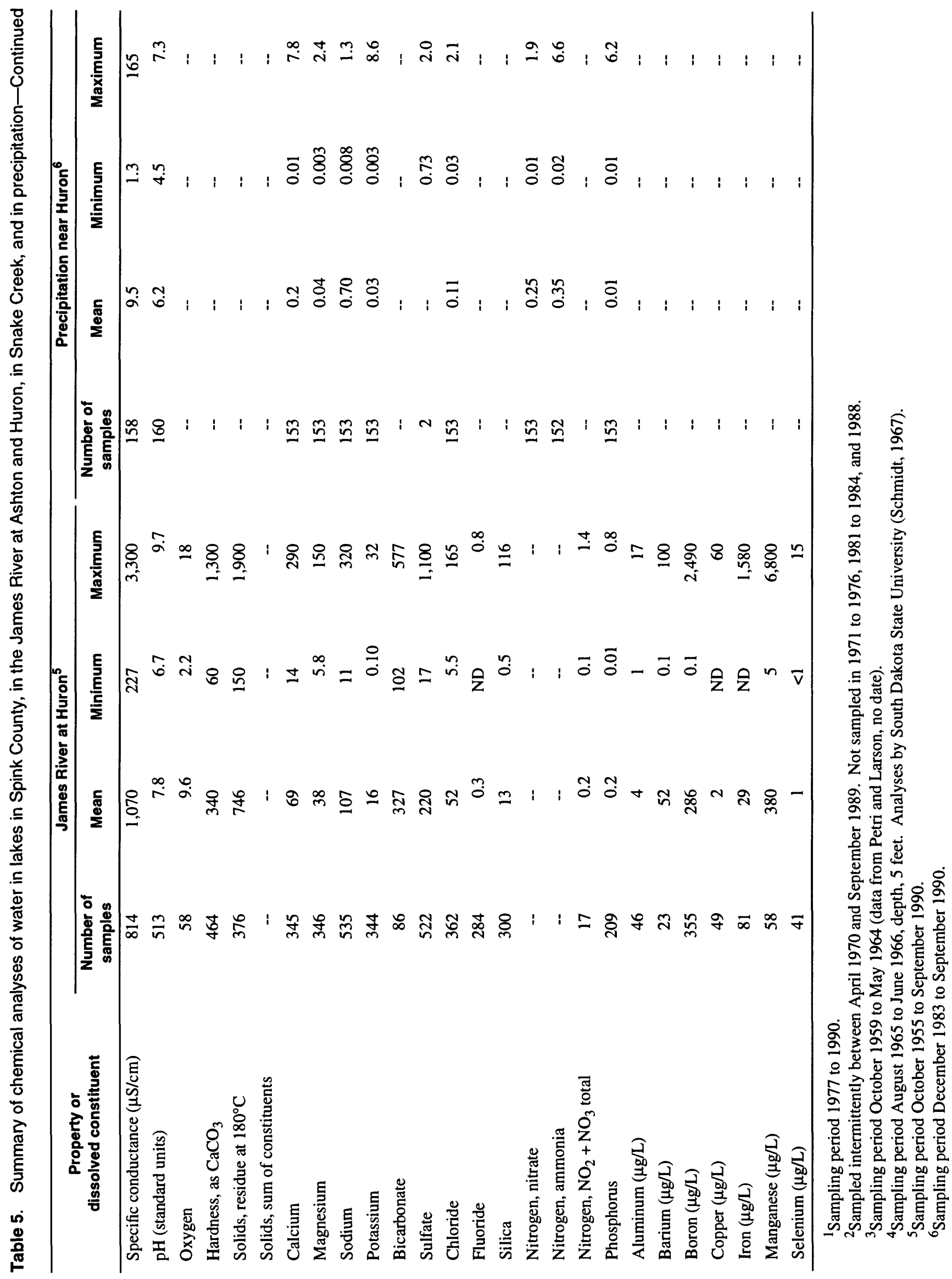



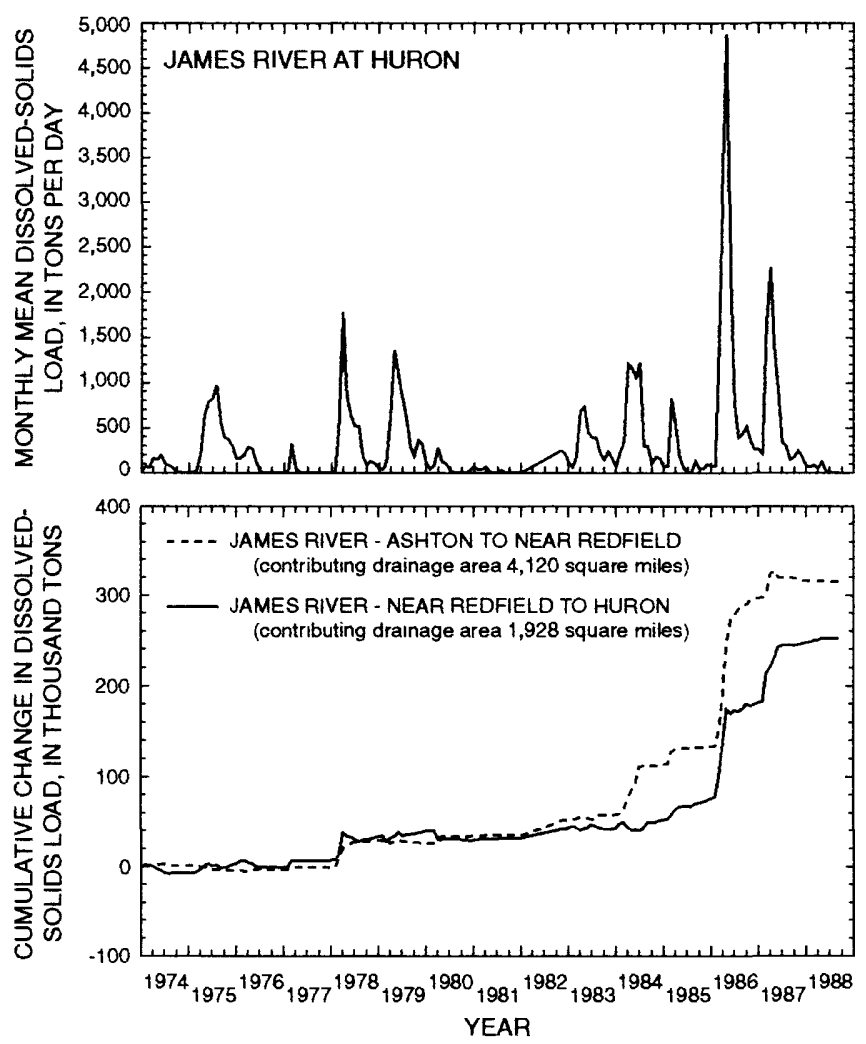

Figure 9. Monthly dissolved-solids load of the James River at Huron and cumulative change in dissolved-solids loads between gaging stations from 1974-88.

\section{GROUND WATER}

Aquifers in Spink County are divided into two groups-those in unconsolidated glacial drift deposits and those in the bedrock. The glacial deposits contain five major and several minor aquifers; the bedrock contains two major and two minor aquifers. Some of the important characteristics of the aquifers are summarized in table 6 . A properly constructed and properly developed well in either type of aquifer may yield more than 500 gallons per minute in areas where an aquifer is thick and very permeable.

\section{Glacial Aquifers}

Most unconsolidated deposits in Spink County are the result of glaciation and collectively are called drift. Along water courses, in some sloughs, and in lakes the drift is covered by deposits of alluvium; locally the drift is covered by windblown sand and silt.
Alluvium in the county consists of poorly sorted, poorly stratified, thin, discontinuous layers of material that range in grain size from clay to gravel. The alluvium underlying the James River flood plain is as much as $\mathbf{2 5}$ feet thick, and that along tributary streams and minor water courses generally is less than 10 feet thick. The alluvium of the James River flood plain contains a much higher proportion of silt than does alluvium elsewhere in the county.

Glacial drift in Spink County can be divided into three major types-till, outwash, and glaciolacustrine material-that differ greatly in physical and hydrologic characteristics. Till, which was deposited directly from or by glacial ice, is a heterogeneous mixture of silt, sand, gravel, and boulders in a matrix of clay. It is the most abundant glacial deposit in the county. Outwash, which was deposited from or by meltwater streams beyond the margin of active glacial ice, consists primarily of layers of clayey or silty sand, sandy gravel, and very permeable well-sorted sand and gravel beds interbedded with layers of sandy and gravelly silt or clay. Glaciolacustrine material was deposited by glacial meltwater in lakes on or adjacent to the continental ice sheet, both as it advanced and as it retreated. In Spink County, glaciolacustrine deposits include varved sediments (thinly laminated material consisting of alternating layers of summer-deposited, light-colored silt and sand and winter-deposited, darkcolored organic-rich clay), penetrated in a few test holes; silt, silty sand, and sandy silt, such as that found in the deeper parts of buried valleys in the bedrock surface; and silty, sandy clay and sandy silt, such as that of the Lake Dakota plain.

Most of the aquifers in glacial drift deposits in Spink County are composed of well-sorted outwash sand and gravel that is very permeable. The sand is mostly medium to very coarse grained, and the gravel is very fine to medium grained. In the southwestern part of the county, the Tulare aquifer is composed of fine-to-medium sand and contains layers of very fine, silty sand, and is less permeable than elsewhere. Deposition of this fine-grained material is a result of temporary ponding of meltwater in narrow lakes between the retreating ice front and the hills to the west. These lakes trapped fine sand and silt in the outwash.

\section{Extent, Depth, and Thickness}

The glacial drift of Spink County contains five major aquifers. These aquifers underlie about 760 square miles (about half of the county) and contain about 3.3 million acre-feet of water in storage. The tops of the aquifers are at depths ranging from 
Table 6. Summary of the characteristics of major aquifers in Spink County [--, data insufficient for an estimate]

\begin{tabular}{|c|c|c|c|c|c|c|c|c|}
\hline Aquifer name & $\begin{array}{c}\text { Estimated } \\
\text { areal } \\
\text { extent } \\
\text { (square } \\
\text { miles) }\end{array}$ & $\begin{array}{c}\text { Maximum } \\
\text { thickness } \\
\text { (feet) }\end{array}$ & $\begin{array}{c}\text { Average } \\
\text { thickness' } \\
\text { (feet) }\end{array}$ & $\begin{array}{l}\text { Range in } \\
\text { depth below } \\
\text { land surface } \\
\text { to top of } \\
\text { aquifer } \\
\text { (feet) }\end{array}$ & $\begin{array}{c}\text { Range of } \\
\text { water level } \\
\text { (feet below } \\
\text { or above (+) } \\
\text { land surface) }\end{array}$ & $\begin{array}{l}\text { Estimated } \\
\text { amount of } \\
\text { water in } \\
\text { storage }{ }^{2} \\
\text { (million } \\
\text { acre-feet) }\end{array}$ & $\begin{array}{l}\text { Range of } \\
\text { reported and } \\
\text { estimated } \\
\text { well yields } \\
\text { (gallons per } \\
\text { minute) }\end{array}$ & $\begin{array}{l}\text { Suitable for } \\
\text { irrigation }\end{array}$ \\
\hline \multicolumn{9}{|c|}{ GLACIAL AQUIFERS } \\
\hline Tulare & 510 & $220+$ & 37 & $0-100$ & $0-50$ & 2.4 & $2-1,200$ & Yes $^{4}$. \\
\hline Elm & 15 & 35 & 13 & $2-40$ & $20-40$ & .02 & $2-100$ & Yes. \\
\hline Altamont & 34 & 70 & 22 & $2-80$ & $5-60$ & .10 & $2-900$ & Yes $^{4}$. \\
\hline Middle James & 160 & 90 & 30 & $10-100$ & $5-30$ & .61 & $2-500$ & Yes $^{4}$. \\
\hline Deep James & 43 & 160 & 36 & $55-364$ & $10-45$ & .20 & $2-1,000$ & Yes $^{4}$. \\
\hline \multicolumn{9}{|c|}{ BEDROCK AQUIFERS } \\
\hline Niobrara & 1,490 & 200 & $5_{40}$ & $80-360$ & $30-50$ & ${ }^{6} 7.6$ & $2-600$ & No. \\
\hline Dakota & 1,500 & 370 & ${ }^{5} 170$ & $740-1,000$ & $+90-65$ & ${ }^{6} 32.6$ & $2-350$ & No. \\
\hline Inyan Kara-Sundance & -- & 80 & -- & $1,150-1,200$ & $+460-+90$ & - & - & No. \\
\hline Minnelusa & -- & 440 & -- & ${ }^{7} 1,265$ & -- & -- & -- & No. \\
\hline
\end{tabular}

\footnotetext{
${ }^{1}$ Arithmetic mean from test-hole data.

${ }^{2}$ Storage estimated by multiplying average thickness times areal extent times a specific yield of 0.20 .

${ }^{3}$ Based on irrigation-water classification diagram (fig. 25).

${ }^{4}$ Though generally suitable for irrigation, in some places the water in the aquifer is not suitable.

${ }^{5}$ Average thickness greater than indicated because not all test holes fully penetrated the aquifer.

${ }^{6}$ Minimum value because average thickness greater than indicated.

${ }^{7}$ Based on only one well.
}

land surface to more than 360 feet below land surface (table 6). The maximum thicknesses of four of the aquifers is more than 50 feet. The aquifers, in order of increasing depth, are the Tulare, Elm, Altamont,
Middle James, and Deep James. These aquifers are correlated with aquifers in adjacent counties on the basis of their altitudes (fig. 10) at or near the Spink County border. The Tulare aquifer in southwestern

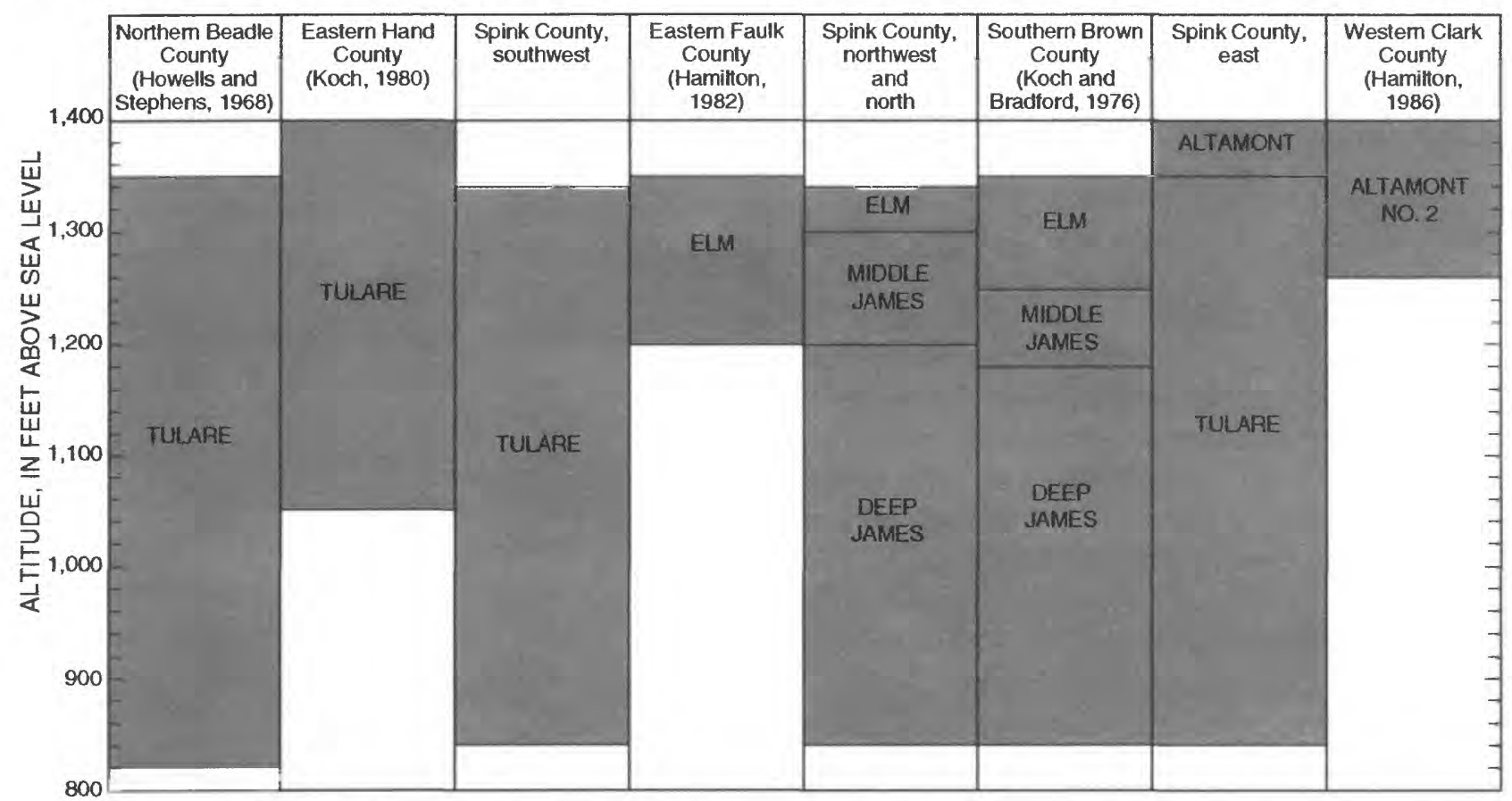

Figure 10. Correlation chart of major glacial aquifers in Spink County and adjacent counties. 
Spink County is the same as the Tulare aquifer in Beadle and Hand Counties (Howells and Stephens, 1968; Koch, 1980). The Elm and Middle James aquifers in Spink County are the same as the Elm aquifer in Faulk County (Hamilton, 1982). The Altamont aquifer is the same as the Altamont no. 2 aquifer in Clark County (Hamilton, 1986), and the Deep James aquifer in northern Spink County is the same as the Deep James aquifer in Brown County (Koch and Bradford, 1976). The locations of and areas underlain by the five major aquifers in glacial drift deposits are shown in figures 11 and 12 .

The Tulare aquifer underlies about 510 square miles in central and southern Spink County (fig. 11) and contains about 2.4 million acre-feet of water in storage. The deposits that make up the aquifer include not only surface and near-surface irregular sheets of outwash and other fluvio-glacial materials, but also older, more deeply buried valley-fill outwash and other permeable, hydraulically connected fill in the deep valleys in the bedrock surface. The bedrock valleys that contain the more deeply buried parts of the Tulare aquifer are part of the same buried valley system that contains the Deep James aquifer in northern Spink County (fig. 12), and the Tulare and Deep James aquifers may be hydraulically connected in T. 117 N., R. 62 W. The SDGS refers to the more deeply buried valley-fill outwash in southern Spink County as the Deep James rather than the Tulare aquifer (Dennis Tomhave, South Dakota Geological Survey, oral commun., May 1996). Depth to the top of the upper parts of the Tulare aquifer ranges from 10 to 80 feet in the middle one-third of the county and from land surface to 100 feet in the southern one-third (sections B-B' and C-C', fig. 13).

The Tulare aquifer is thickest where thicker parts of the surface or near-surface outwash overlie thick or moderately thick valley-fill outwash in the deep valleys in the bedrock surface; maximum thickness exceeds 220 feet. In the surface and near-surface sheets of outwash in the Tulare aquifer, the aquifer is thickest, more than 50 feet, in shallow buried channels in drift that are 1 to 4 miles wide in the southern onethird of the county, and in shallow buried channels in the drift that are less than 2 miles wide in the middle one-third of the county. The average thickness of the Tulare aquifer is about 37 feet. That part of the Tulare aquifer lying east of the James River has no known connection to that part of the aquifer west of the river at shallow depth (above an altitude of 1,100 feet) in Spink County. Any hydraulic connection between the two parts of the aquifer that is within Spink County probably is through permeable deposits in the buried deep bedrock valleys.

The Elm aquifer underlies about 15 square miles of northwestern Spink County (fig. 11). The top of the aquifer is at depths of from 2 feet to as much as 40 feet below land surface. The average thickness of the aquifer in Spink County is about 13 feet.

The Altamont aquifer occupies buried channels underlying about 34 square miles along the eastern side of Spink County (fig. 11). The aquifer is in two layers. The top of the shallow layer commonly is within 2 to 10 feet of land surface. The depth to the more extensive lower layer ranges from 35 to 80 feet. The average thickness of the Altamont aquifer is about 22 feet.

The Middle James aquifer underlies about 160 square miles of Spink County (fig. 11). Depth to the top of the aquifer ranges from 10 to 100 feet below land surface. The average thickness of the aquifer is about 30 feet.

The Deep James aquifer, which underlies an estimated 43 square miles in northern Spink County (fig. 12), is composed of hydraulically connected deposits in the fill of the buried deep valleys in the bedrock surface. The aquifer area shown in figure 12 is based on available well-log data, but these data are insufficient to fully outline the aquifer. Because this aquifer is made up mostly of deposits of valley-fill outwash, the area shown in figure 12 for the Deep James aquifer also is based on bedrock topography (fig. 4). Materials that now form the Deep James aquifer were later overridden and eroded by glaciers, eroded by streams, and then buried by subsequent glacial deposits; therefore, the deposits that now form the Elm and Middle James aquifers in some places directly overlie the deposits that form the Deep James aquifer and are indistinguishable from them (see sec. 24 of T. 120 N., R. 63 W., geologic section A-A' in fig. 13). In such places the identification of the contact between aquifers is arbitrarily made on the basis of altitude above sea level. Where only a few feet of one aquifer overlies or underlies another, all of the aquifer material present may be represented as one aquifer. Depths to the top of the Deep James aquifer range from 55 feet to more than 360 feet below land surface. The thickness of the aquifer averages about 36 feet and ranges from a few feet to 160 feet. 


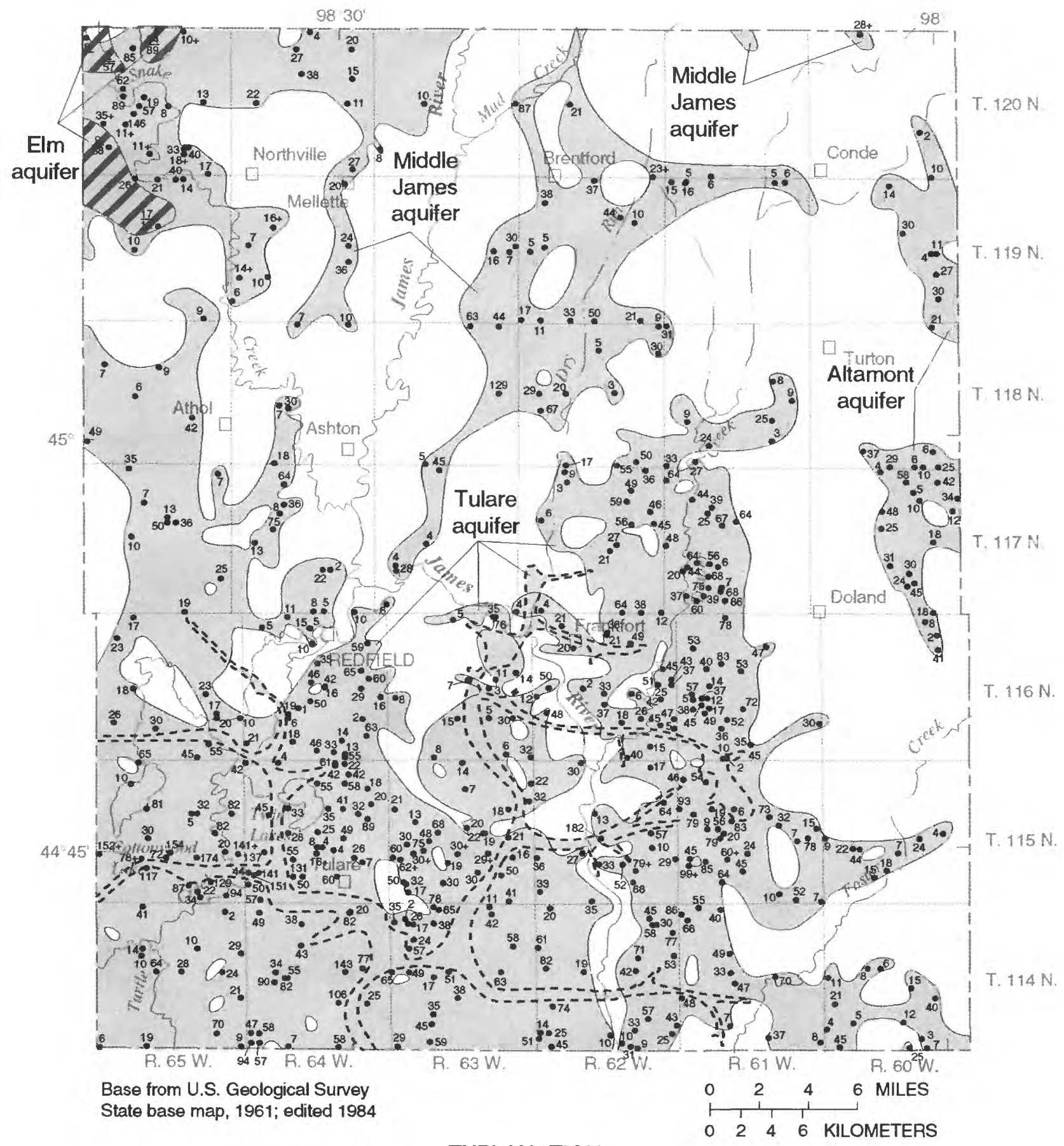

\section{EXPLANATION}

APPROXIMATE AREA UNDERLAIN BY ELM AQUIFER
APPROXIMATE AREA UNDERLAIN BY TULARE,
MIDDLE JAMES, AND ALTAMONT AQUIFERS
INFERRED LOCATION OF PERMEABLE DEPOSITS IN
THE TULARE AQUIFER THAT ARE PART OF THE
SAME DEPOSITIONIAL EPISODE AS THE DEEP
JAMES AQUIFER (see figure 12)

- $\frac{34+}{89}$ WELL OR TEST HOLE--Numbers are thickness, in feet, of upper and lower aquifers. A plus $(+)$ indicates a thickness greater than shown.

Figure 11. Extent and thickness of the Tulare, Middle James, Elm, and Altamont aquifers. 


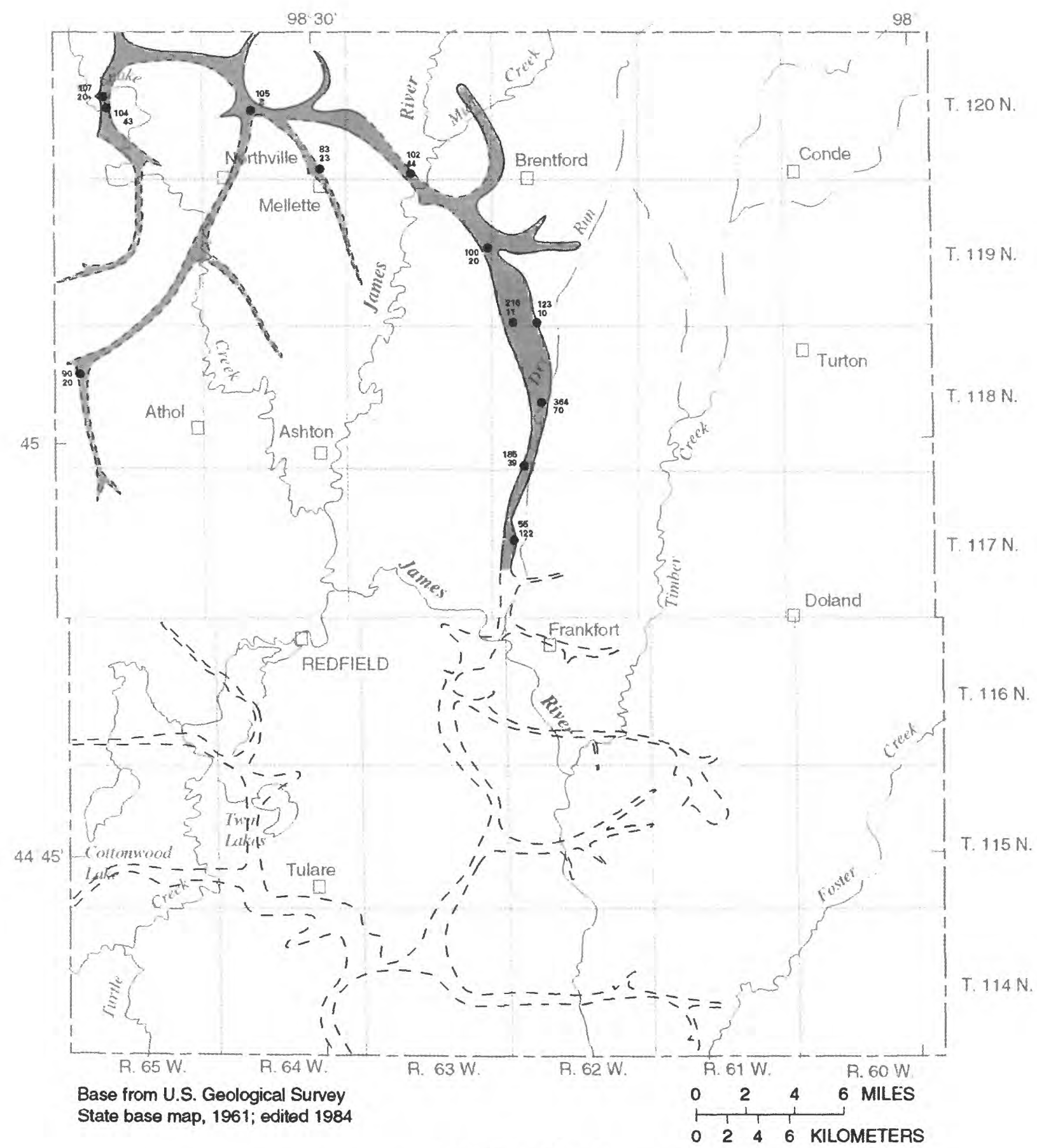

EXPLANATION

APPROXIMATE LOCATION OF DEEP JAMES AQUIFER--Boundary dashed where location is inferred

I: - INFERRED LOCATION OF PERMEABLE DEPOSITS IN THE TULARE AQUIFER THAT ARE PART OF THE SAME DEPOSITIONIAL EPISODE AS THE DEEP JAMES AQUIFER

- WELL OR TEST HOLE IN DEEP JAMES AQUIFER--First number is depth, in feet, to top of aquifer. Second number is aquifer thickness, in feet.

Figure 12. Extent, depth, and thickness of the Deep James aquifer. 


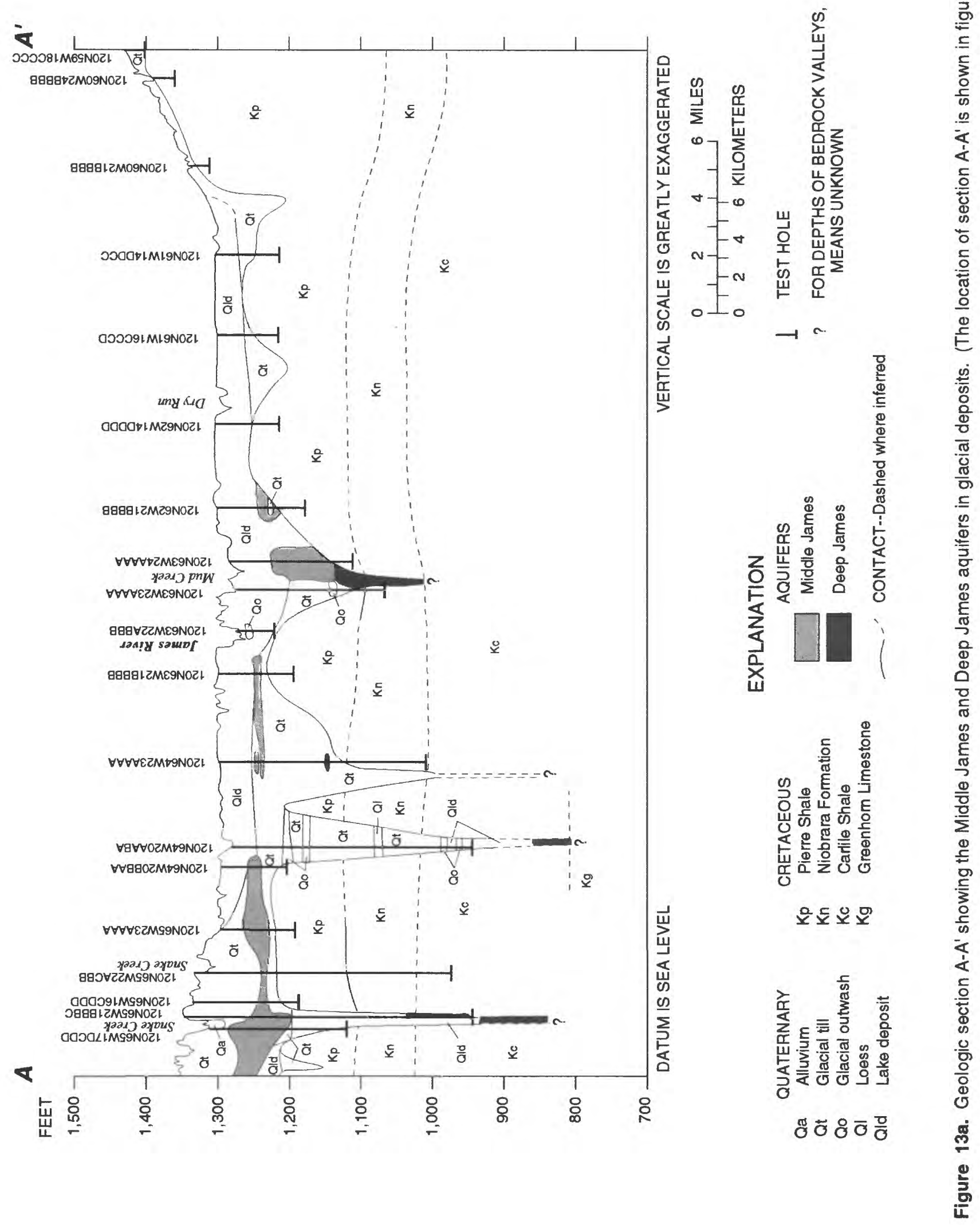




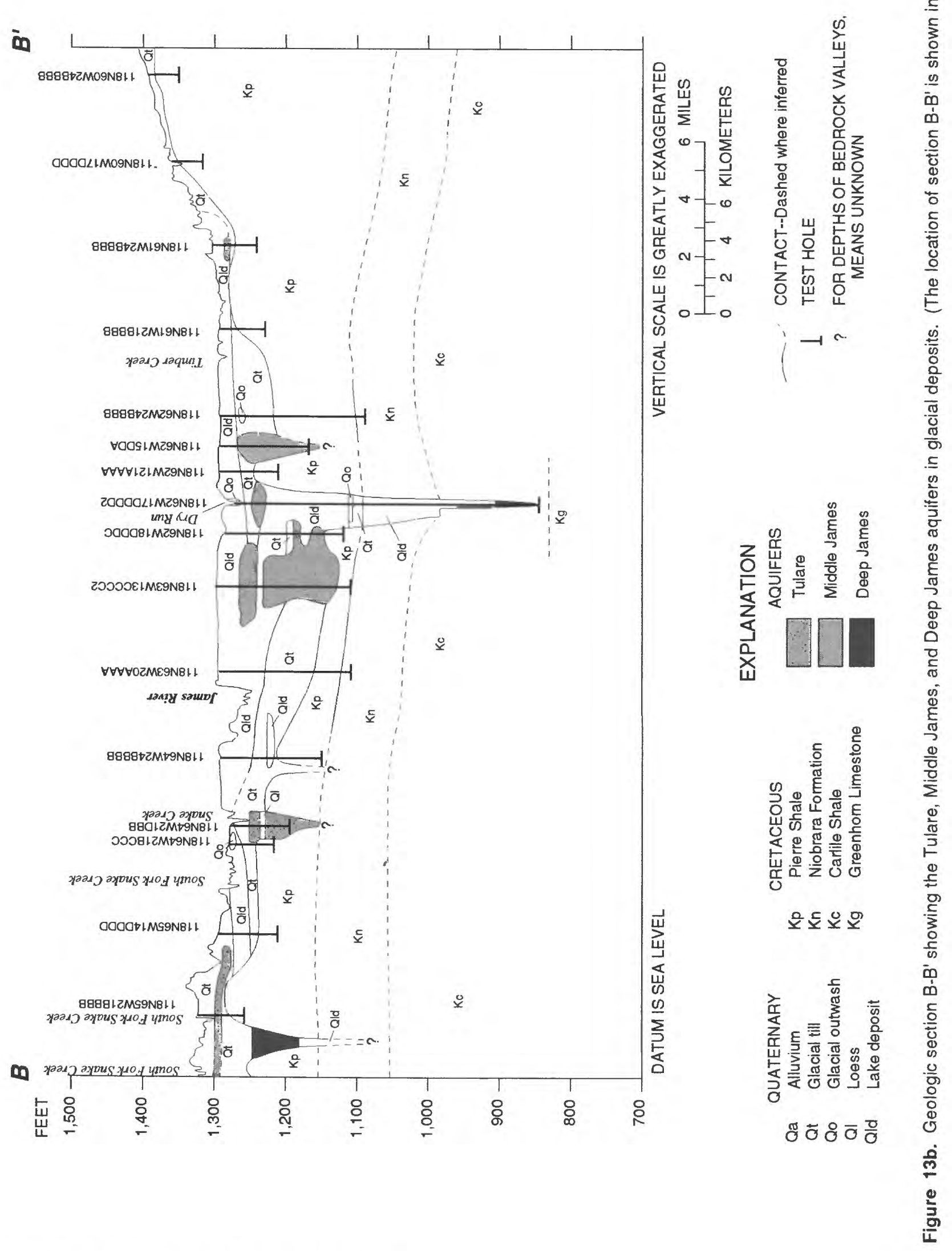




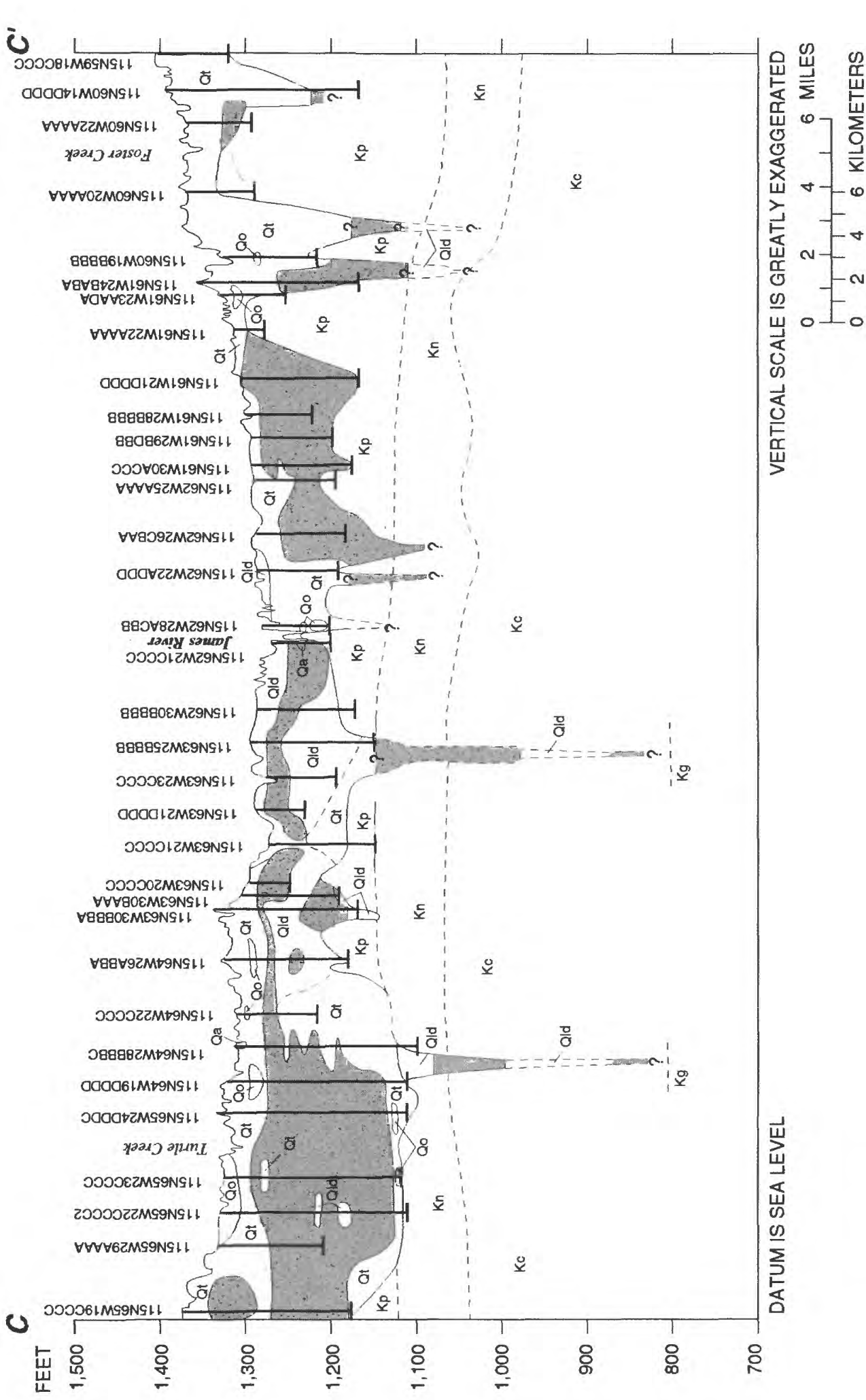

完

㟧学

立昰

क

क응

㓉

㟧之

虰㟔

i

폰

山 㟧

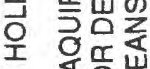

인

$\stackrel{w}{⺊}$

$\rightarrow$

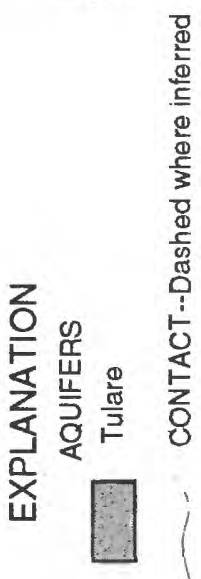

ลิ

㐫

西

0.

ว융ํㅇ

㟧क के

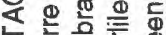

岩高立

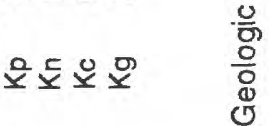

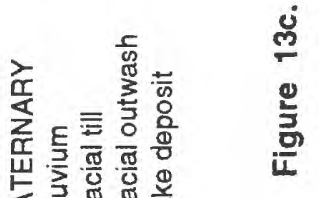

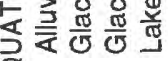

ชீ ชั ชํㅁㅇㅁ 


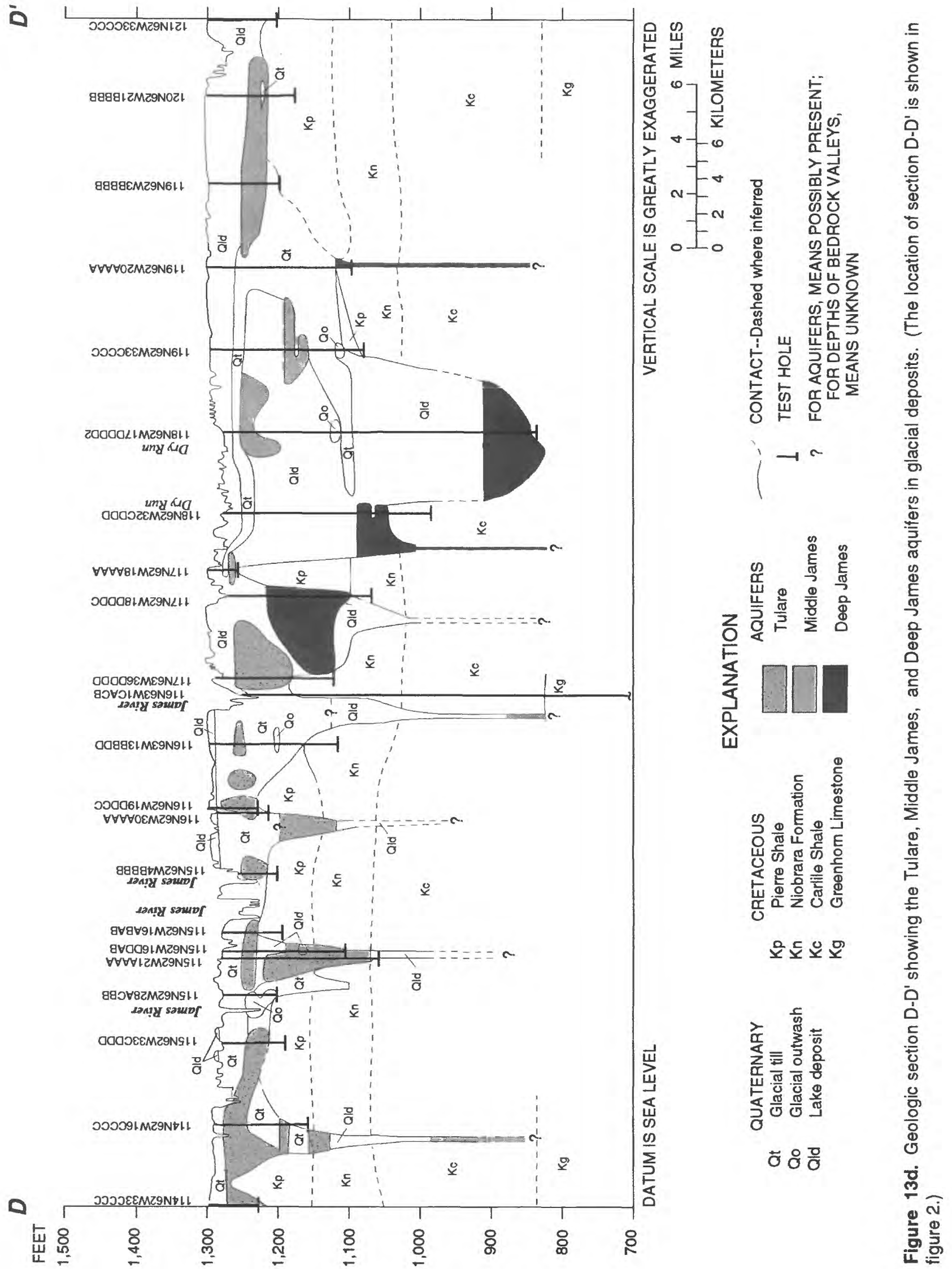




\section{Recharge, Movement, and Discharge}

Most of the recharge to aquifers in glacial drift deposits in Spink County is by infiltration of precipitation and by ground-water inflow from adjacent areas. Water seeps downward to the aquifers in unconsolidated deposits through soil and permeable deposits that overlie them and then moves from these areas of recharge toward areas of discharge. Minor amounts of recharge come from aquifers in the bedrock that are in contact with aquifers in the glacial deposits. Also, leakage through ruptured well casings or infiltration of uncontrolled discharge from flowing wells completed in bedrock may recharge aquifers in the glacial deposits. Recharge from precipitation, mainly from rain and snowmelt in spring, varies from year to year and from place to place. Infiltrating water must fill the soil to its moisture-holding capacity before any recharge from precipitation can take place. When the ground thaws in the spring, the amount of water infiltrating from melted snow and from rainfall can exceed the moisture-holding capacity of the soil, and the excess may move downward to recharge aquifers. The rise of water levels each spring indicates that recharge in the spring is significant. A smaller rise in water level usually occurs in late fall and early winter because of the decrease in discharge of water by evapotranspiration and cessation of pumping for irrigation.

Precipitation in summer and fall rarely contributes to the ground-water supply because most of it evaporates, is used by vegetation, or is retained as soil moisture. Precipitation in amounts equal to or less than the daily average evaporation would be unavailable for either soil-moisture replenishment or recharge from May through October. During this period, average potential evapotranspiration in Spink County is 33 inches and average precipitation is 13.6 inches. In late fall, winter, and early spring, infiltration is prevented by frozen ground and because most precipitation is in the form of snow or ice.

The amount of precipitation that infiltrates the soil is governed by the permeability of the soil. Infiltration rates, which are a measure of permeability, range from less than 0.02 to as much as 20 inches of water per hour in Spink County soils. Where the most permeable surface materials are present, infiltration of precipitation is most rapid. The soils in these areas range in thickness from less than 10 inches to 5 feet, and in moisture-holding capacity from about 1.2 to about 1.6 inches per foot of thickness (U.S. Soil
Conservation Service, 1954, and written commun., 1987). Because of the high infiltration rates, nearly all precipitation and runoff that reach the permeable areas infiltrate into the soil; the exception being when the water table is at land surface, in which situation runoff to surface water occurs. In the spring, and following heavy or prolonged moderate rainfalls in the summer and fall, the soil moisture-holding capacity may be exceeded and aquifers immediately underlying the soil are recharged.

Where a layer of till overlies an aquifer, recharge from infiltration of precipitation is limited by the very low permeability of the till. The maximum infiltration rate in unweathered till in Spink County probably is less than 0.001 inch per hour (estimated from laboratory and field-test data). Because soil developed on till generally has high moisture-holding capacity ( 1.75 to 2.64 inches per foot of thickness) and till has very low permeability, little recharge to the aquifers takes place through the till (see also the Hydraulic Properties section). Other sources of recharge that are locally important are overland runoff onto very permeable soils that overlie aquifers, subsurface inflow in aquifers from both the west and east, subsurface leakage from artesian wells, seepage from closed depressions that contain water, and seepage along drainageways that carry runoff (Hopkins and Petri, 1963, p. 35-36).

Ground-water inflow from areas adjacent to Spink County is a major source of recharge to aquifers in the drift in parts of the county. Where aquifers that extend outside Spink County are exposed at the surface, or are overlain by permeable materials, they are recharged by infiltration of precipitation. Water in the aquifers moves downgradient; thus, where a recharge area outside the county is at a higher altitude than the water level of the aquifer in Spink County, water moves through the aquifer into the county.

Most recharge to the Tulare aquifer is by infiltration of precipitation, both in and west of Spink County. Local recharge to the east side of the aquifer is by vertical infiltration of precipitation and seepage from depressions and drainageways through 20 to 60 feet of glacial drift. Recharge from precipitation in 1990 is estimated to have been nearly 20,000 acre-feet (2.8 inches) for 130 square miles of T. 114 and $115 \mathrm{~N}$., R. 60 and 61 W., and in T. 116 N., R. 61 and 62 W., where the relatively steep slope of the potentiometric surface or lower transmissivity of the aquifer indicates rapid movement of ground water (fig. 14). Water in T. 116 N., R. 62 W., and T. 117 N., R. 61 and 62 W. 


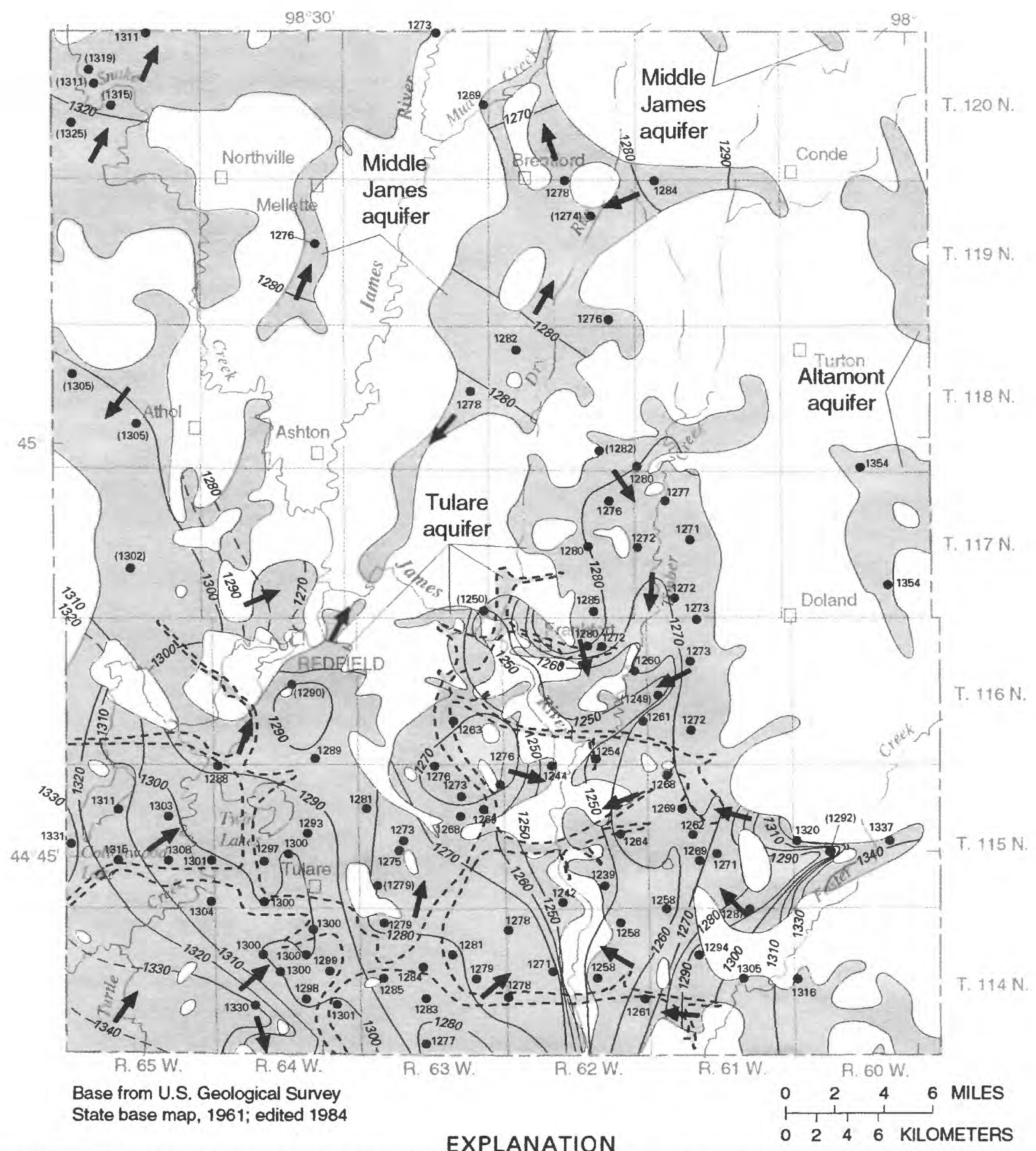

APPROXIMATE AREA UNDERLAIN BY TULARE, MIDDLE JAMES, AND ALTAMONT AQUIFERS

INFERRED LOCATION OF PERMEABLE DEPOSITS IN THE TULARE AQUIFER THAT ARE PART OF THE SAME DEPOSITIONIAL EPISODE AS THE DEEP JAMES AQUIFER (see figure 12)

- WELL--Number is altitude of water level, in feet above sea level. A parenthesis indicates a measurement other than spring 1990.

DIRECTION OF GROUND-WATER MOVEMENT

- 1300- - POTENTIOMETRIC CONTOUR--Dashed where inferred.

Shows altitude at which water would have stood in tightly cased, nonpumping wells in spring 1990.

Contour interval 10 feet. Datum is sea level.

Figure 14. Potentiometric contours of the Tulare, Middle James, and Altamont aquifers, spring 1990. 
mostly moves southward. However, in the southwestern part of the county, movement is mostly eastward or northeastward toward the James River. Recharge by subsurface inflow westward through glacial till along the eastern side of the county is estimated to be 10 acre-feet. Recharge by subsurface inflow from Hand County to the west is estimated to be nearly 20,000 acre-feet. Most of the water moves northeastward and then eastward toward the James River or southeastward into Beadle County from T. 114 N., R. 64 W.

Subsurface inflow to the Tulare aquifer from all sources was estimated to be about 34,000 acre-feet and subsurface outflow from the county was estimated to be about 6,000 acre-feet, based on flow-net calculations. The difference, 28,000 acre-feet, includes discharge by wells (13,000 acre-feet) and discharge by evapotranspiration (15,000 acre-feet). The estimated evapotranspiration, excluding the trench of the James River, is in reasonable agreement with the value of 20,500 acre-feet ( 0.6 inch) obtained from a numerical flow model of the aquifer (Kuiper, 1984, figs. 24 and 25). The steady-state model solution for the evapotranspiration rate for the entire area of the Tulare aquifer in Spink County is 24,500 acre-feet per year ( 0.7 inch per year).

Recharge to the Elm and Middle James aquifers in 1990 is estimated to have been 45,000 acre-feet, based on the average net rise of 2 feet for water levels in 15 observation wells completed in those aquifers. Discharge from these two aquifers, mostly by evapotranspiration, is estimated to have been about 28,000 acre-feet per in 1990. Subsurface outflow northward is estimated to average only about 2,000 acre-feet per year; this small volume of discharge is based on hydraulic conductivity and the low slope of the potentiometric surface, which averages only 1 to 2 feet per mile (fig. 14).

\section{Hydraulic Properties}

The hydraulic properties of natural deposits of most interest to those developing, using, or managing water resources are hydraulic conductivity (permeability), transmissivity, and coefficient of storage. Deposits of low permeability, such as till, are barriers to the movement of ground water and are called confining layers or confining beds. Saturated deposits of fairly high permeability, such as outwash and other fluvio-glacial deposits, yield usable quantities of water to wells and springs and are called aquifers. In relatively permeable materials (aquifers), the hydraulic properties can be determined near a well by a test during which the well is pumped, usually at a constant rate, and the changes in water level in the pumped well, and in suitably sited observation wells, are measured at regular intervals both during pumping and during the "recovery" period following cessation of pumping. Analysis of the test data can yield the average field hydraulic conductivity, transmissivity, and storage coefficient of the aquifer near the pumped well. In some instances, analysis of this type of aquifer test can determine if recharge is occurring near the well, if a large increase or decrease in aquifer transmissivity occurs near the well, or if an aquifer boundary is near the well.

Hydraulic conductivity (field permeability) is a measure of the rate of flow of water, in cubic feet per day, through a cross section of 1 square foot of material under a unit hydraulic gradient (a unit hydraulic gradient is 1 foot of pressure head loss or gain per foot of material traversed). Hydraulic conductivity usually is expressed in units of feet per day.

The transmissivity is the rate of flow of water, in cubic feet per day, at the prevailing water temperature, and under a unit hydraulic gradient, through each vertical strip of aquifer 1 foot wide having a height equal to the thickness of the aquifer. Transmissivity is expressed in square feet per day. Transmissivity, which also is equal to the hydraulic conductivity multiplied by the aquifer thickness, is the parameter that usually is directly determined in an aquifer test.

The coefficient of storage (specific yield) is the volume, in cubic feet, of water released from or taken into storage in each vertical column of aquifer having a base area of 1 square foot when there is a 1-foot change in hydraulic head. Coefficient of storage is dimensionless and is expressed as a decimal. In an artesian aquifer, the volume of water released from or taken into storage in response to a change in head is determined by the compressibility of the aquifer and of the water; storage coefficients of artesian aquifers may range from about 0.00001 to 0.001 . In a watertable aquifer, the volume of water released from or taken into storage is determined partly by the compressibility of the saturated part of the aquifer and of the water and partly by gravity drainage from the zone through which the water table moves; storage coefficients in water-table aquifers range from about 0.05 to 0.30 .

The hydraulic properties discussed above are possessed by all natural materials, including clay, shale, siltstone, sandstone, and granite, not just by sand and gravel. For less permeable and nearly impermeable materials, determining hydraulic conductivity, 
storage coefficient, and other properties, can be, and often is, more difficult, time consuming, and expensive than is testing aquifer material, and can require highly specialized equipment.

Several recent summaries of the hydrologic properties of till in eastern South Dakota (Barari, written commun., 1983; Barari and Hedges, 1985; Montgomery, 1986; Cravens and Ruedisili, 1987; Barari and Cowman, 1988; and CENDAK Drainage Steering Committee, 1987, 1988) give the average hydraulic conductivity of unweathered till as about 0.00001 foot per day, but it can range from less than 0.000001 to as much as 0.07 foot per day where it is very sandy and silty. The hydraulic conductivity of aquifer materials can range from less than 0.2 foot per day, where deposits are fine grained or silty or clayey, to more than 1,900 feet per day.

Most of the irrigation wells in Spink County are in the Tulare aquifer because it generally is very permeable and it is fairly thick, averaging 37 feet (table 6). Yields of wells completed in the Tulare aquifer locally exceed 1,000 gallons per minute, espe- cially in the southern one-third of the county where the aquifer is very thick, extensive, and readily recharged through sandy soil. However, in T. 115 N., R. 60 W., yields are less than 500 gallons per minute because the aquifer is buried beneath till, is finer grained, and has a lower transmissivity.

Analysis of a series of 15 pumping tests, 1 to 14 days in duration, on large-capacity wells in the Tulare aquifer indicates that the aquifer has a large range of hydraulic properties (table 7). The lower half of the values of hydraulic conductivity was used for the previously discussed flow-net calculations because many of the tested wells were irrigation wells that had been placed in areas of known large hydraulic conductivity; the values used are thought to better represent hydraulic conductivity for the entire aquifer. The tests, analyzed by the Theis (1935) non-equilibrium method, were made by the U.S. Geological Survey in cooperation with the U.S. Bureau of Reclamation as a part of drainage investigations for the Oahe irrigation project (LaRocque and others, 1955).

Table 7. Summary of pumping tests of the Tulare aquifer

[Information from LaRocque and others, 1955; <, less than the value shown; --, not estimated]

\begin{tabular}{|c|c|c|c|c|c|c|c|c|c|}
\hline \multirow[b]{2}{*}{$\begin{array}{c}\text { Test } \\
\text { number }\end{array}$} & \multirow[b]{2}{*}{$\begin{array}{l}\text { Location of } \\
\text { pumped weil }\end{array}$} & \multirow[b]{2}{*}{$\begin{array}{l}\text { Duration } \\
\text { of tests } \\
\text { (days) }\end{array}$} & \multirow[b]{2}{*}{$\begin{array}{c}\text { Average } \\
\text { rate of } \\
\text { pumping } \\
\text { (gaiions } \\
\text { per } \\
\text { minute) }\end{array}$} & \multirow[b]{2}{*}{$\begin{array}{l}\text { Aquifer } \\
\text { thickness } \\
\text { (feet) }\end{array}$} & \multirow[b]{2}{*}{$\begin{array}{l}\text { Depth of } \\
\text { pumped } \\
\text { weil } \\
\text { (feet) }\end{array}$} & \multicolumn{3}{|c|}{ Hydraulic properties } & \multirow[b]{2}{*}{ Remarka } \\
\hline & & & & & & $\begin{array}{c}\text { Average } \\
\text { hydraulic } \\
\text { conductivity } \\
\text { (feet per } \\
\text { day) }\end{array}$ & $\begin{array}{c}\text { Trana- } \\
\text { missivity } \\
\text { (square feet } \\
\text { per day) }\end{array}$ & $\begin{array}{c}\text { Storage } \\
\text { coefficient }\end{array}$ & \\
\hline FHA-1 & 114N63W26ACAA & 1 & 680 & 42 & 65 & 800 & 33,400 & - & $\begin{array}{l}\text { No estimate of storage coeffi- } \\
\text { cient because recovery was } \\
\text { measured only in pumped } \\
\text { well. }\end{array}$ \\
\hline FHA-2 & $114 \mathrm{~N} 63 \mathrm{~W} 24 \mathrm{BCDD}$ & 1 & 1,000 & 50 & 64 & 1,900 & 92,900 & - & \\
\hline 4 & 114N63W14DCCC3 & 5 & 150 & 66 & 90 & 170 & 11,400 & 0.1250 & Delayed yield from storage. \\
\hline 3 & 114N63W17DDDD3 & 5 & 100 & 41 & 85 & 160 & 6,400 & .0008 & \\
\hline 5 & 114N64W20AAAA & 8 & 150 & 82 & 122 & 140 & 11,500 & .0037 & Delayed yield from storage. \\
\hline 14 & $115 \mathrm{~N} 63 \mathrm{~W} 27 \mathrm{DBDC}$ & 3 & 40 & 30 & 50 & 110 & 3,200 & .0860 & Delayed yield from storage. \\
\hline 8 & 115N64W19DDDD4 & 7 & 110 & 30 & 92 & 140 & 4,300 & .0006 & \\
\hline 9 & 115N65W28AAAA & 14 & 300 & 50 & 105 & 110 & 5,400 & .0008 & \\
\hline 18 & $115 \mathrm{~N} 65 \mathrm{~W} 27 \mathrm{CBBC} 2$ & 3 & 300 & 30 & 97 & $<1,400$ & $<42,000$ & .0020 & Delayed yield from storage. \\
\hline $27 \mathrm{~A}$ & 116N61W 8DDDD3 & 1 & 800 & 84 & 77 & $<460$ & $<38,000$ & .0280 & Delayed yield from storage. \\
\hline 26 & 117N62W13BADA & 3 & 150 & 50 & 70 & $<180$ & $<9,200$ & .0430 & Delayed yield from storage. \\
\hline 24 & $117 \mathrm{~N} 64 \mathrm{~W} 4 \mathrm{CBDD} 2$ & 1 & 260 & 71 & 110 & $<30$ & $<2,000$ & -- & Complex boundary conditions \\
\hline 23 & 118N64W34BCDD & 3 & 50 & 27 & 70 & $<5$ & $<130$ & -- & Complex boundary conditions \\
\hline
\end{tabular}


The maximum well yield for the Deep James aquifer is nearly as large as for the Tulare (table 6) because the deeper layers of the Deep James aquifer locally contain much coarse sand and gravel.

\section{Water-Level Fluctuations}

Water-level fluctuations in wells are caused by seasonal changes in recharge and discharge. Water levels generally rise in spring due to recharge from snowmelt and rainfall. During summer, levels generally drop because of decreased recharge, increased evapotranspiration, discharge to streams, and increased pumpage. Levels rise again in fall when evapotranspiration and pumpage decrease.

Water levels in three shallow observation wells screened in clayey glacial till or clayey lake silt showed different rates and magnitudes of fluctuation from 1989 to 1991 because of the different permeabilities of the deposits, and because of different discharge conditions (fig. 15). Water-table fluctuations in shallow glacial till at wells 114N64W14DDDD3 and 115 N60W19BBBB2 are more rapid than they are for the well in lake silt, 119N62W17CCCC3, because the till is sandy, fractured, and more permeable than is the lake silt. Water levels in wells completed in the till also respond rapidly to discharge from nearby irrigation wells. The rise in water level due to spring recharge at well 115 N60W19BBBB2 was 1.3 feet per month in 1990 and 2.0 feet per month in 1991 . Rises in water level caused by recharge at well 114N64W14DDDD3 were 0.6 foot per month in 1989 and 1990 and 0.9 foot per month in 1991. Part of the recharge was from subsurface inflow from the west and this was slower than the predominantly vertical recharge at well 115N60W19BBBB2.

The water table dropped slowly at well 119N62W17CCCC3 in 1989 because of discharge by evapotranspiration through dense, clayey lake silts that have low permeability. This trend was reversed by increased recharge from greater than normal precipitation in the summer of 1990 , but the rise was slow and averaged only 0.2 foot per month until March 1991. The rise in water level caused by spring recharge in 1991 was much more rapid, nearly 2 feet per month, because of greater than normal precipitation ( 7 inches above normal).

Long-term (at least 10 years of record) trends of water levels for wells in glacial till or in aquifers in unconsolidated deposits correlate closely with the cumulative departure from normal precipitation (fig. 16) and indicate that recharge to aquifers increases rapidly after an increase in precipitation. The annual net rise of the water level in well 115 N63W3BBBB, completed in glacial till, averaged slightly more than 0.2 foot from 1953 to 1991 and exceeded 1 foot only in 1957, 1958, 1962, and 1986. The 4-foot fluctuation of the water level in this well in 1990 was caused by removing water from the well to collect a water sample for analysis. The water level in 1989 was 3.5 feet above the 1953 level because the 1953 level occurred during a 5-year drought when cumulative departure from normal precipitation was 8 inches below normal; the 1989 water level came after the 1983 to 1986 wet period when the cumulative departure from normal precipitation had increased by 26 inches (fig. 16).

Water levels for well 114N64W11BBBB, which is screened in the Tulare aquifer, show a general longterm declining trend of peak annual water levels that totaled 11.5 feet between 1953 and 1982 (fig. 16). Short-term reversals of this trend occurred from 1965 to 1972 and from 1983 to 1986 , intervals of much greater than normal precipitation. Recharge increases rapidly with increased precipitation at this site because the aquifer is covered by only 15 feet of lacustrine sand and sandy, permeable drift. Future long-term declining trends could possibly drop annual low water levels to more than 30 feet below land surface at this well if droughts are more severe or pumpage is larger than it was between 1953 and 1983.

The largest decline in water level at an observation well in Spink County between 1977 and 1991 was nearly 30 feet. This occurred in well 117 N60W26BCCC (fig. 16), which is completed in the Altamont aquifer and is about one-half mile from an irrigation well. The rise of the water level was rapid from 1982 to 1986 because of decreased pumpage and increased recharge. Recharge is both from infiltration of precipitation and by subsurface inflow from the east and north. Water-level declines are largest for the Altamont aquifer at this site because the aquifer is narrow, which restricts subsurface inflow to the well site.

Only one of the 90 observation wells of the network measured in Spink County by the DENR Division of Water Rights has shown a long-term declining trend in water level that extended through the wet period of 1983 to 1986 . The annual minimum water level in well $115 \mathrm{~N} 61 \mathrm{~W} 28 \mathrm{BBBB}$ (fig. 17) in the East James Management Unit of the Tulare aquifer 

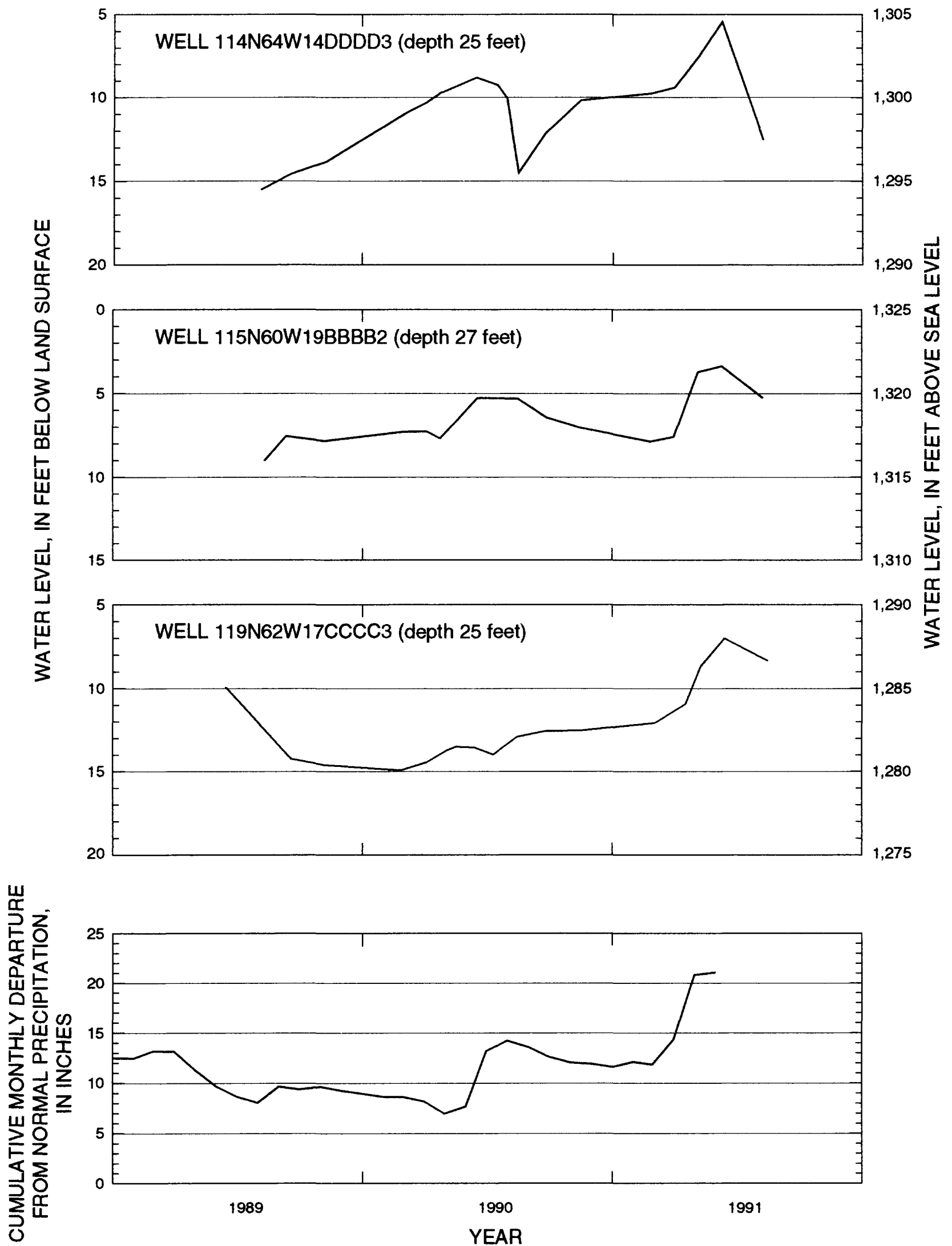

Figure 15. Water-level changes in shallow wells and cumulative departure from 1951-80 normal precipitation near Redfield. 

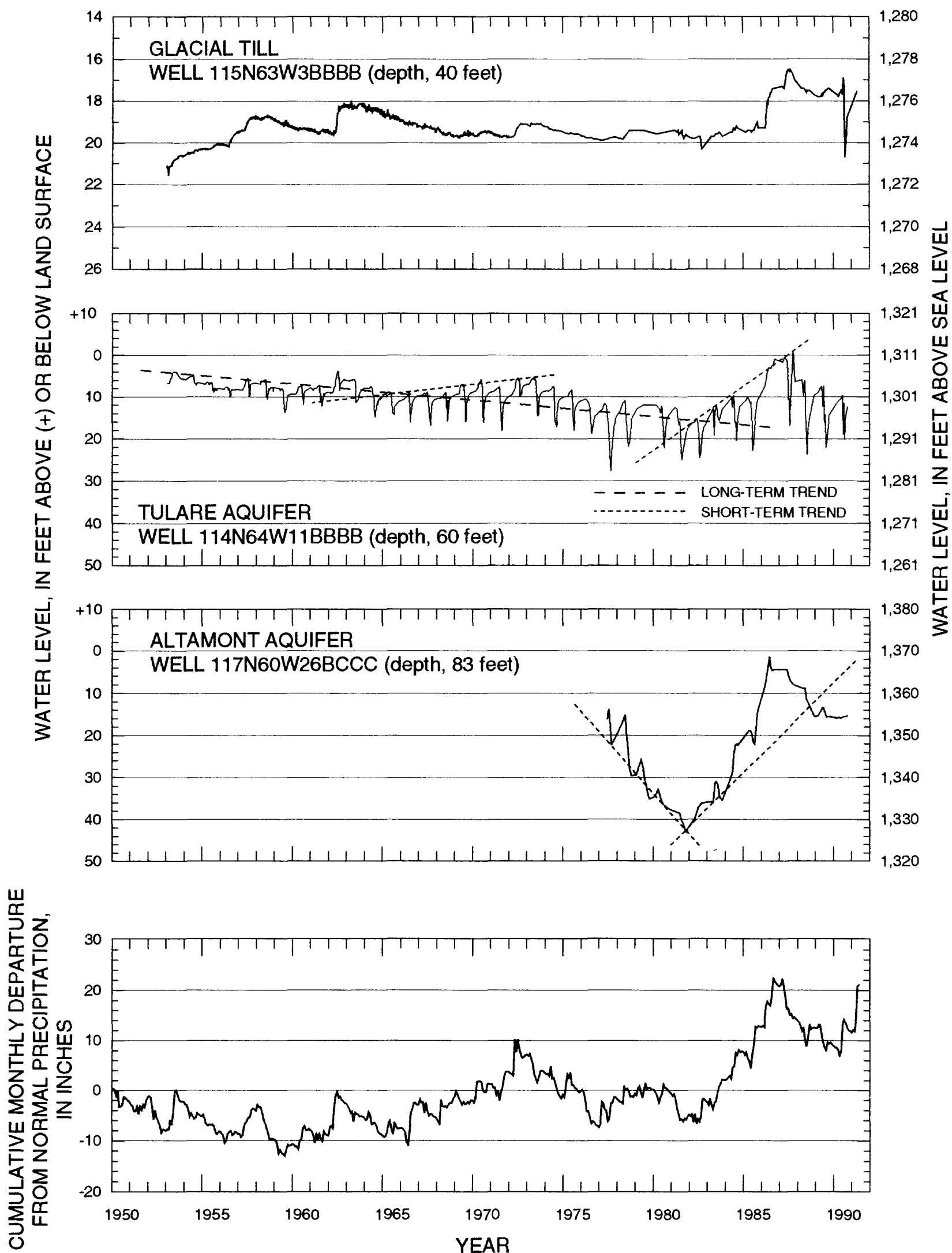

Figure 16. Water-level trends in wells in glacial till and aquifers for calendar years 1951-91 and cumulative departure from 1951-80 normal precipitation near Redfield. 

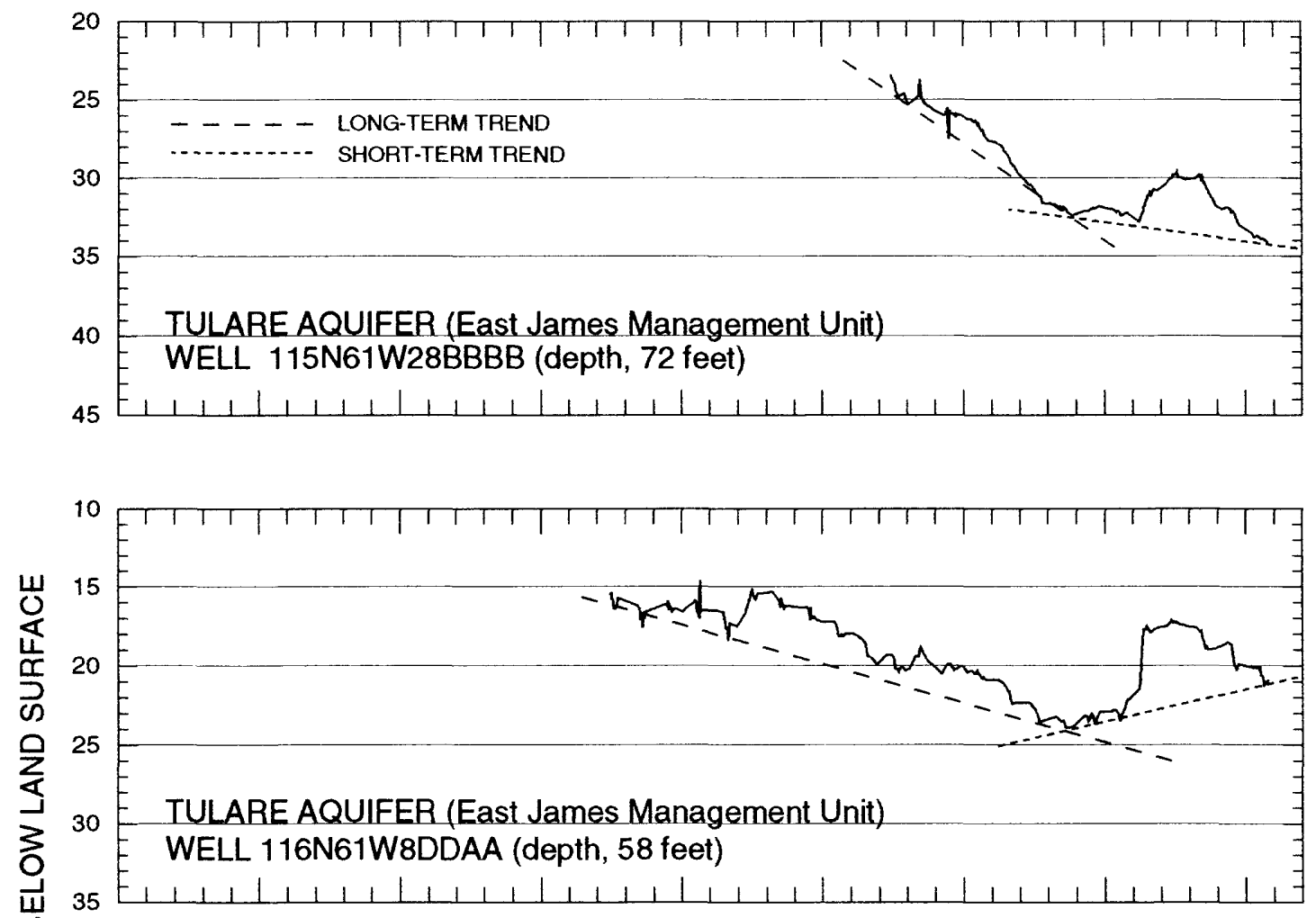

0
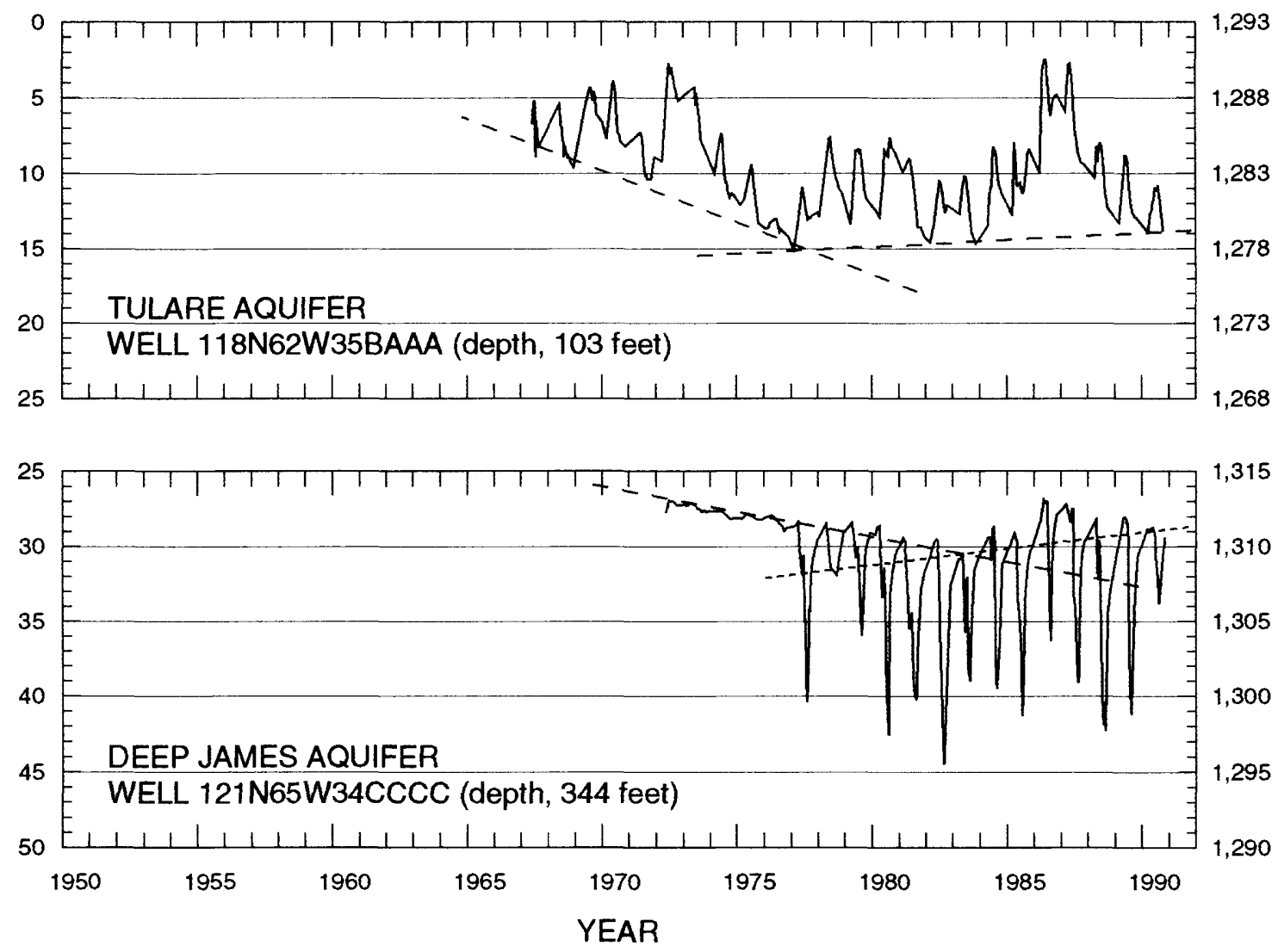

Figure 17. Long-term declining water-level trends in wells in glacial aquiters. 
declined from about 25 feet below land surface in 1977 to 34 feet below land surface in 1990. The decline was at a rate of 1.2 feet per year during the dry period from 1977 to 1983 . The water level generally recovered between 1984 and 1987 when precipitation and recharge were large, but the decline resumed in 1987 at a rate of about 1.5 feet per year. This continuing decline was caused by increased pumpage (reportedly 50 to 100 . percent) of nearby irrigation wells during 1988 and 1989.

Another observation well in the East James unit of the Tulare aquifer, 116N61W8DDAA, is within 3 miles of 24 irrigation wells. The annual minimum water level in this well had a long-term declining trend of 0.5 foot per year from 1967 to 1983 . However, this trend reversed from 1984 to 1990 , when the rise in annual minimum water level averaged 0.4 foot per year (fig. 17).

A well near the northern end of the Tulare aquifer (118N62W35BAAA), more than 2 miles from the nearest irrigation well, had a 1-foot rise in annual minimum water level from 1976 to 1990 . This rise is so slight that it is insignificant; a small increase in pumpage or decrease in recharge could reverse this trend.

Between 1983 and 1990, a rising trend that totaled 1.7 feet in annual maximum water level occurred in a 344-foot well screened in the Deep James aquifer, 121N65W34CCCC (fig. 17), probably due to decreased pumping of irrigation wells during a period of above-normal precipitation. The Deep James aquifer is recharged by infiltration of precipitation through more than $\mathbf{2 0 0}$ feet of sandy glacial drift, but the effect of increased recharge is masked by the large annual fluctuations of water level caused by pumping.

\section{Bedrock Aquifers}

Four bedrock aquifers store more than 40 million acre-feet of water at depths of from 80 to about 1,300 feet below land surface in Spink County. The aquifers, in order of increasing depth, are the Niobrara, Dakota, Inyan Kara-Sundance, and Minnelusa (table 1, fig. 18).

\section{Niobrara Aquifer}

The Niobrara Formation is mostly a firm, tan to gray to dark-gray, highly calcareous, silty shale that yields water, and therefore is an aquifer, in its upper part. The Niobrara Formation is overlain throughout much of Spink County by, in addition to glacial drift, the Pierre Shale, a light-gray to dark-gray to black, calcareous to non-calcareous, greasy, relatively impermeable shale that is as much as $\mathbf{3 5 0}$ feet thick. The Crow Creek Member of the Pierre Shale and one or more 10- to 40-foot-thick layers of calcareous marl in the Gregory Member of the Pierre Shale are often mistaken for the Niobrara Formation. However, even the lowest of the calcareous beds in the Pierre Shale are at least 40 to 100 feet above the Niobrara and none of them yield water to wells.

\section{Extent, Depth, Thickness, and Well Yields}

The Niobrara aquifer, called "chalk" or "chalkstone" by drillers, is in the Niobrara Formation and underlies almost all of the county at depths of 80 to 450 feet below land surface (figs. 13, 18, and 19). The altitude of the top of the formation ranges from below 1,060 feet above sea level in buried valleys in the bedrock surface and in the northeastern corner of the county, to more than 1,180 feet above sea level at several places throughout the county. The Niobrara Formation has been deeply eroded locally by preand/or interglacial and glacial streams and is thin or absent in some narrow, buried, bedrock valleys (figs. 13, 18, and 19). The deepest buried channels in the bedrock valleys may be no more than 300 feet wide in some places, and may be so deeply incised into the bedrock surface that they completely penetrate the underlying Carlile Shale and reach the Greenhorn Formation. This is particularly true for the "main channel" that crosses Spink County from Brown to Beadle Counties.

Where not truncated by Pleistocene erosion, the Niobrara Formation in Spink County is about 80 to 90 feet thick (figs. 18 and 19), though well drillers occasionally report thickness of as much as 200 feet. A sandy shale, sometimes in contact with but other times as much as 50 feet below the base of the Niobrara, correlates with the Codell Sandstone Member of the Carlile Shale. The Codell and Niobrara form a single aquifer south of Spink County (Howells and Stephens, 1968, p. 27). The Codell Sandstone generally is not reported by drillers in Spink County and probably is not an aquifer even though, at one well in southeastern Spink County, the Codell is $\mathbf{5 0}$ feet below the base of the Niobrara and is 20 feet thick. 


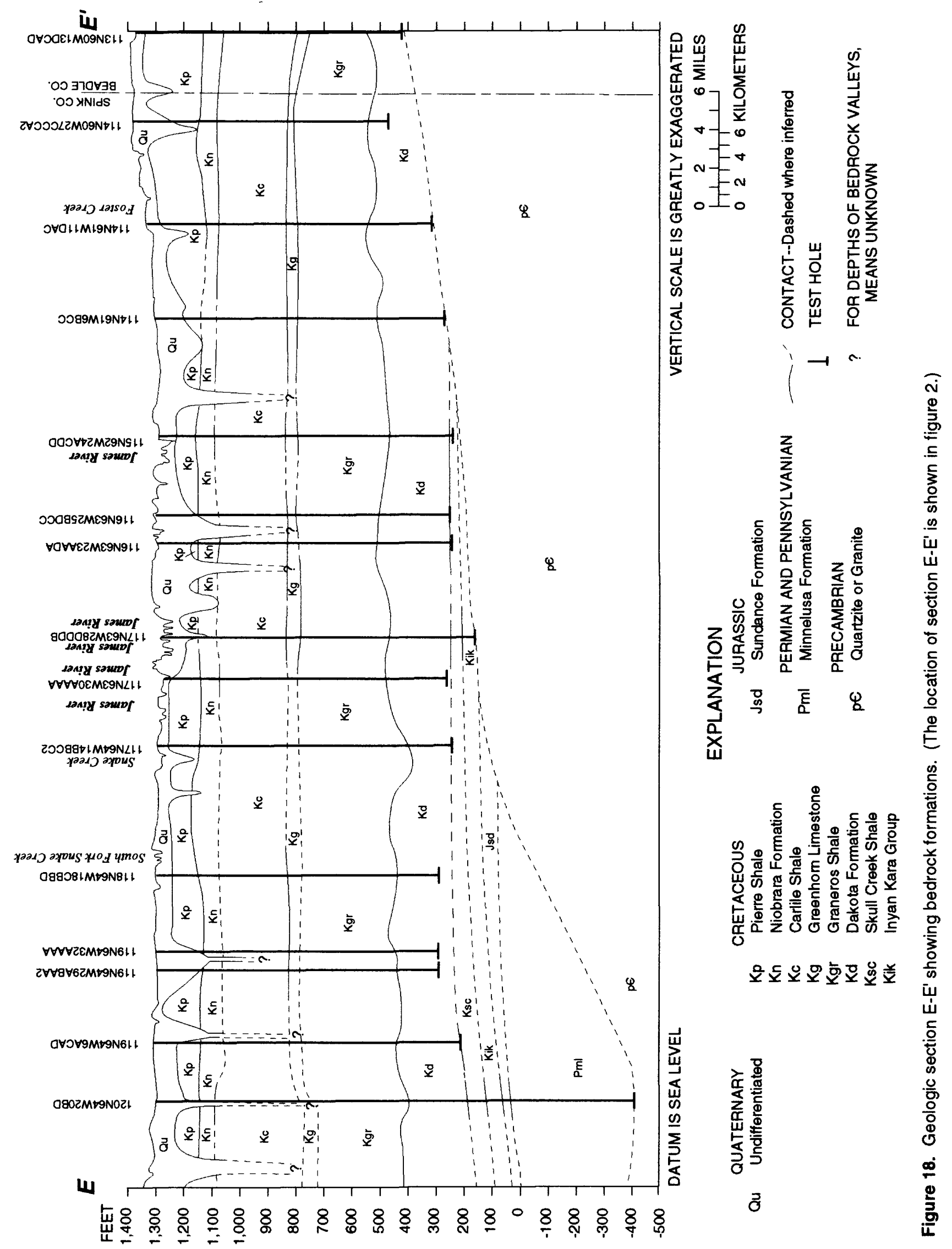




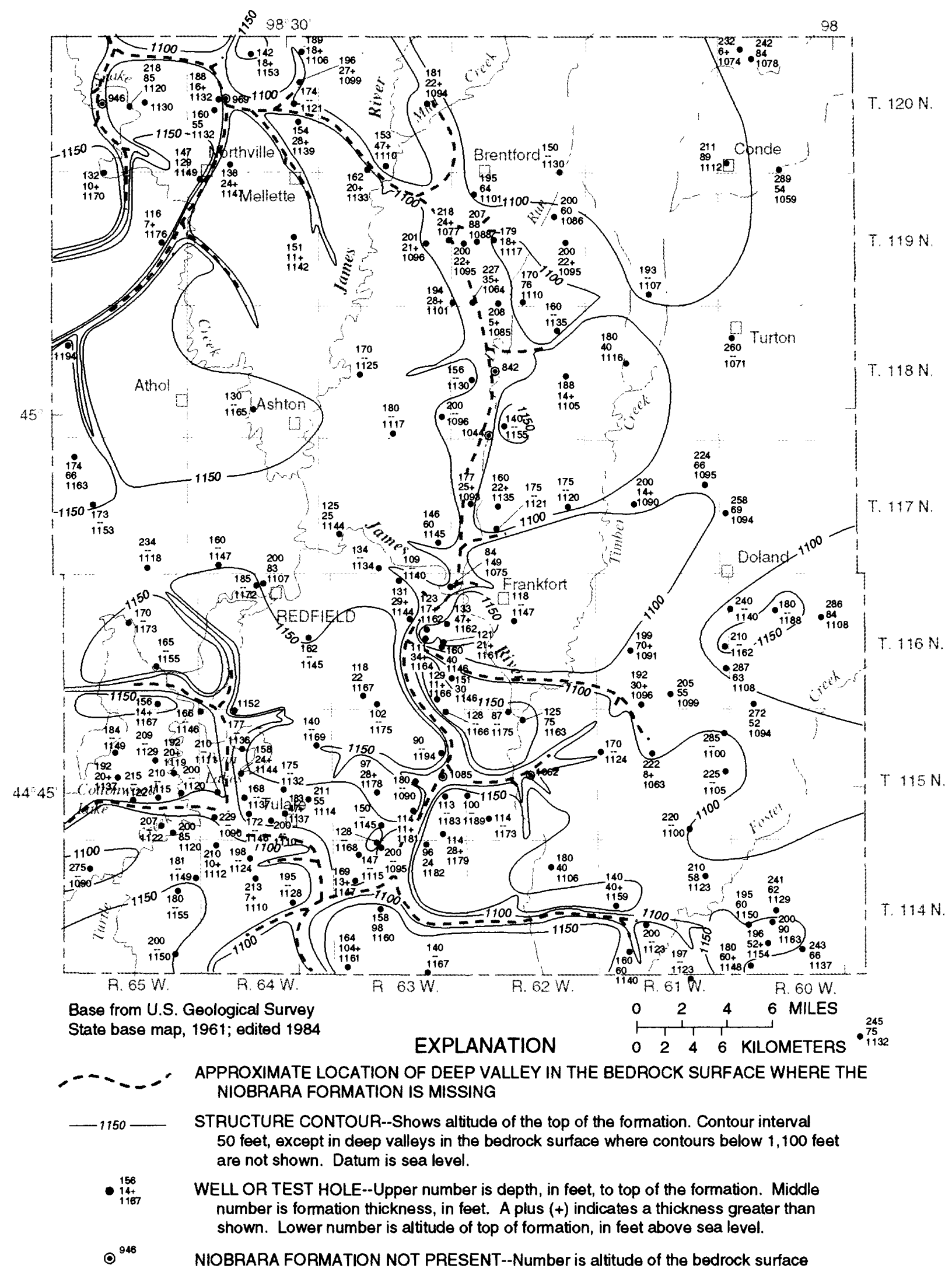

Figure 19. Depth, thickness, and structure contours of the top of the Niobrara Formation which contains the Niobrara aquifer. 
The Niobrara aquifer is very permeable, especially in its upper part where drillers often report a rapid loss of drilling fluid. An irrigation well developed in the aquifer at $116 \mathrm{~N} 63 \mathrm{~W} 14 \mathrm{CABB}$ is reported to yield 600 gallons per minute.

\section{Recharge, Movement, and Discharge}

The major predevelopment source of recharge to the aquifer in the Niobrara is unknown. Before development of ground-water supplies began in the 1880 's, the Niobrara probably did not receive much, if any, recharge from overlying aquifers for two reasons. First, the overlying, nearly impermeable Pierre Shale thickens and serves as a barrier to the downward movement of water north, east, and west of Spink County. Second, the potentiometric surface of water in the aquifer was at an altitude of about 1,400 feet, or more than 100 feet above the land surface in those parts of the James River Valley where permeable drift is in contact with the Niobrara aquifer. Thus, the Niobrara discharged water to, rather than received recharge from, the drift before 1880 .

Since development beginning in the 1880's, however, the aquifer probably has begun to receive recharge from aquifers in the overlying drift where buried bedrock valleys (see figs. 13, 18, and 19) are deep enough to penetrate the Niobrara. Such recharge occurs because well development has resulted in a lowering of the potentiometric surface of the Niobrara aquifer from an altitude slightly above 1,400 feet in 1885 to as low as 1,245 feet by 1966 . Most of the recharge occurs on the southern or eastern sides of the buried valleys, the "downgradient" sides with respect to the original potentiometric surface in the Niobrara.

The aquifer in the Niobrara probably also receives recharge from aquifers in the Greenhorn Limestone and Dakota Formation, and deeper aquifers where they are present, by leakage through the corroded casings of many deep wells. Discharge of water from the Niobrara is into buried outwash at places where the Niobrara potentiometric surface is still high enough to permit such discharge and, possibly, by subsurface outflow.

\section{Dakota Aquifer}

The Dakota aquifer is made up of the permeable siltstone and sandstone beds of the Dakota Formation (Dakota Sandstone), a thick sequence of interbedded shale, siltstone, and sandstone. Beds of permeable sandstone are from 5 to 40 feet thick and compose 30 to 70 percent of the Dakota Formation. The top of the Dakota often is interpreted by drillers as the top of the first 5- to 10-foot-thick sandstone below the Greenhorn Formation. For wells where geophysical well logs are available, geologists and hydrologists often place the top of the Dakota above where drillers do, in less permeable material, based on perceived facies changes from shale to siltstone and sandstone. In the past, drillers and water users have divided the Dakota into an upper sandstone, called the "first flow," and a lower sandstone, called the "second flow." Extensive development of the Dakota aquifer and the subsequent decline of artesian pressure has resulted in mixing of water from the two sandstone units to the extent that the artesian pressure and water quality are nearly the same in both.

\section{Extent, Depth, Thickness, and Well Yields}

The Dakota aquifer underlies the entire county at depths of 740 to about 1,000 feet below land surface (fig. 20). The aquifer is confined beneath 700 to 800 feet of Cretaceous shale formations and overlies Precambrian crystalline rocks and, in part of western Spink County, beds of the Skull Creek Shale, Inyan Kara Group, and possibly, the Sundance Formation. Except for sandstones in the Inyan Kara Group and Sundance Formation, both overlying and underlying rocks commonly are relatively impermeable. The altitude of the top of the Dakota increases from less than 360 feet above sea level in the northwestern part of the county to more than 610 feet above sea level in the southeastern part. The formation is more than 200 feet thick throughout most of Spink County and is more than 300 feet thick in some areas; however, it may be less than 200 feet thick in the southeastern corner of the county.

The yield of 2-inch-diameter wells with 100 - to 200 -foot lengths of slotted openings ranges from 4 to 30 gallons per minute for flowing wells and from 20 to 70 gallons per minute for pumped wells. Wells more than about 30 years old generally have flows of less than 2 gallons per minute because their casings have corroded through and they leak below the surface, or because they are nearly plugged with mineral deposits. A 9-inch-diameter municipal well at Redfield is reported to pump 350 gallons per minute. The well has 106 feet of stainless-steel, wire-wound screen that has a slot width of 0.05 inch. 


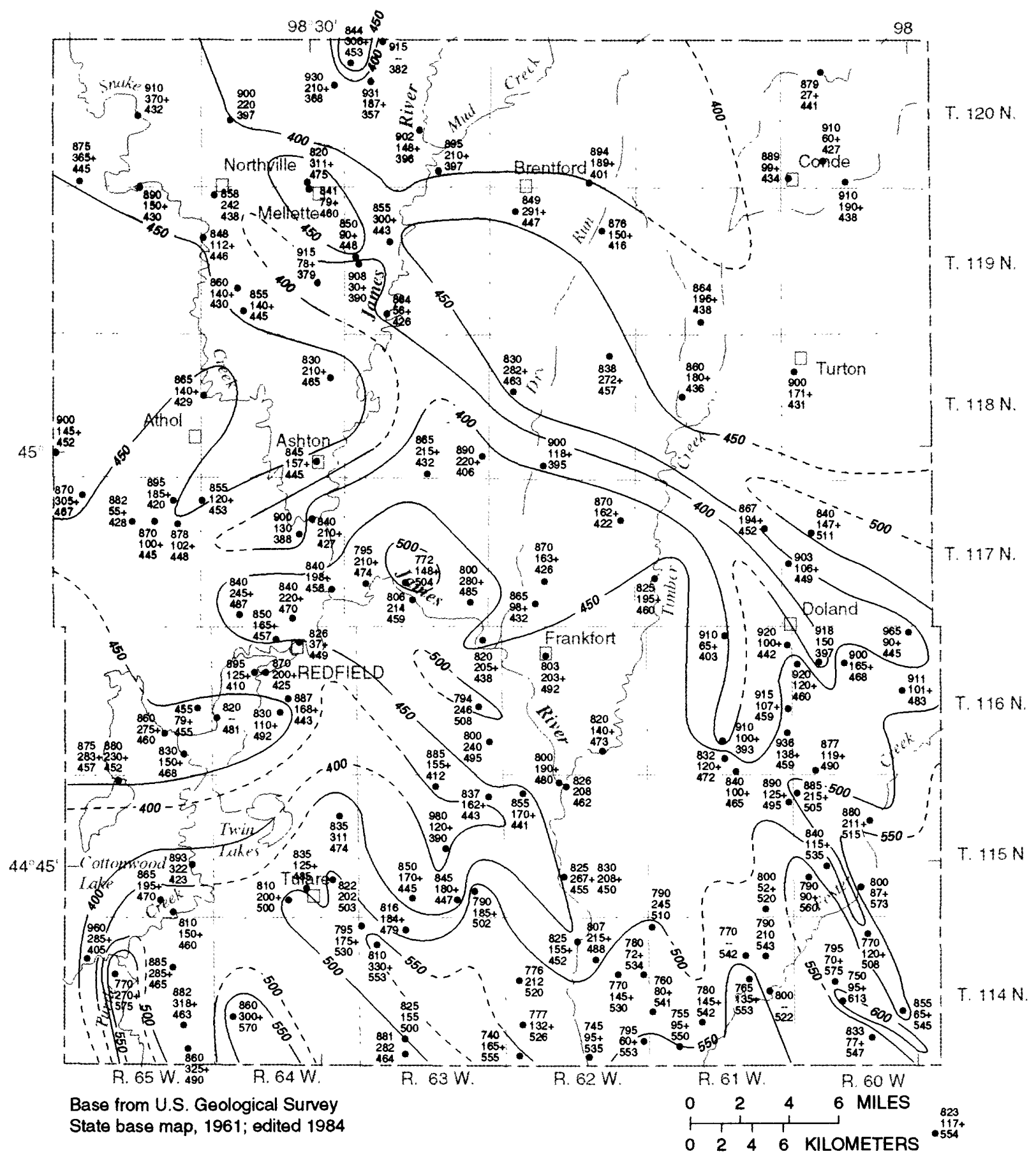

EXPLANATION

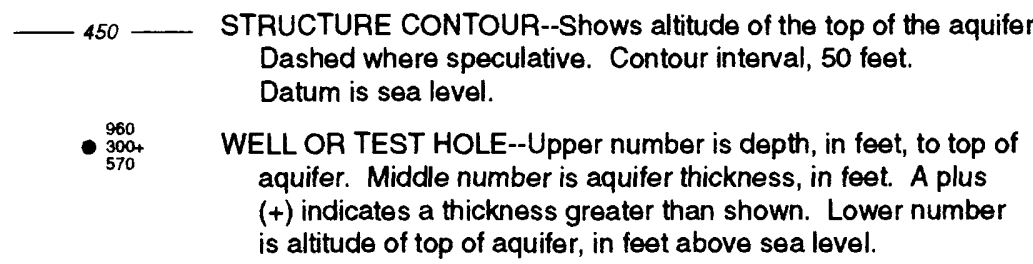

Figure 20. Depth, thickness, and structure contours of the top of the Dakota aquifer. 
Prior to development of the Dakota aquifer in the 1880's, the direction of water movement and the slope of the potentiometric surface in the aquifer in eastern South Dakota was from west to east. Intensive development of the aquifer greatly reduced the artesian head (as much as 415 feet at Redfield) and created a large basin or depression in the potentiometric surface in the James River valley. As a result, the natural west-to-east movement of water in the Dakota has reversed in part of eastern South Dakota and water in the Dakota aquifer now (1980-89) is moving westward from beneath the Prairie Coteau to Spink County (fig. 21). Thus, major recharge to the Dakota aquifer in Spink County comes from subsurface inflow from the west, estimated as 4,600 acre-feet per year, and from the east, estimated as 1,500 acre-feet per year. The hydraulic gradient representing the flow from the west is about 5 to 10 feet per mile in the northern half of the county and is 5 to 25 feet per mile in the southern half. Gradients are steepest in the southwestern part of the county because of recharge to the Dakota from underlying higher pressure aquifers. Flow from the west is larger than flow from the east because the ultimate source of recharge to the Dakota is from the west; flow from the east is a relatively local condition due to differential head decline in the James valley and it eventually may cease due to decreasing pumpage.

There are irregularities in the potentiometric surface of the Dakota in Spink County because of large withdrawals through flowing wells, spatial variations in hydraulic characteristics of the aquifer, and large areal differences in leakage from underlying aquifers.

An elongated 30-foot cone of depression in the potentiometric surface in the area of T. $116 \mathrm{~N}$., R. $64 \mathrm{~W}$., sec. 3 is due to large withdrawals for more than 100 years by the City of Redfield. Troughs in the potentiometric surface tend to coincide with large numbers of flowing wells located along the James River and its tributaries. Wells at lower altitudes tend to discharge at a higher rate than wells in uplands.

Recharge from deeper, higher pressure aquifers probably is limited to the western one-third of the county. Recharge from all sources, from the west, east, and below, is estimated to be 6,200 acre-feet per year and nearly balances the estimated discharge through wells of 5,800 acre-feet per year.
The artesian head of the Dakota aquifer has declined about 350 feet in the last 100 years as a result of withdrawals of more than 400,000 acre-feet of water through wells. The original pressures in 12 artesian wells drilled before the year 1900 in the Lake Dakota plain ranged from 80 to 177 pounds per square inch at land surface and averaged 140 pounds per square inch, which is equivalent to an artesian head of 323 feet above land surface (Hopkins and Petri, 1963, p. T30). Initial flows of as much as 2,000 gallons per minute for wells 6 to 8 inches in diameter caused a rapid drop in pressure and yields. By 1954, the average pressure of 61 wells in the Lake Dakota plain was 12.5 pounds per square inch, equivalent to an artesian head of only 29 feet above land surface.

Water levels for three observation wells in the Dakota aquifer have declined 7 to 60 feet between 1949 and 1989 because discharge has exceeded recharge (fig. 22). However, water levels have stabilized or risen since 1982 because other surface- and ground-water sources have been developed and less use is being made of the Dakota aquifer for stock and domestic water. Also, many farms have recently connected to the WEB Rural Water System and no longer use wells completed in the Dakota aquifer for a domestic water supply. Water levels probably could again decline with the return of severe drought or from industrial and municipal expansion, either of which could cause greater use of water from the Dakota.

\section{Inyan Kara-Sundance Aquifer}

The extent of the Inyan Kara-Sundance aquifer in Spink County is not known. The aquifer has been penetrated by wells near the northwestern and southwestern corners of the county. The Inyan Kara aquifer is equivalent to the Fall River Formation of earlier reports for counties to the west (Koch, 1980; Hamilton, 1982). The Inyan Kara-Sundance aquifer at well 120N64W20BD was penetrated at a depth of about 1,195 feet, an altitude of about 100 feet above sea level. At 120N65W22ACBB, the top of the aquifer was penetrated at about the same depth and altitude. The aquifer is composed of as much as 70 feet of sandstone and sandy shale that is moderately permeable. An artesian pressure of 200 pounds per square inch and an initial flow of 80 gallons per minute through 2-inch casing were reported by the driller at the second site in 1982 . Seven years later, the average flow was 6 gallons per minute and the partially shut-in pressure at a flow of 2 gallons per minute was 57 pounds per square inch. 


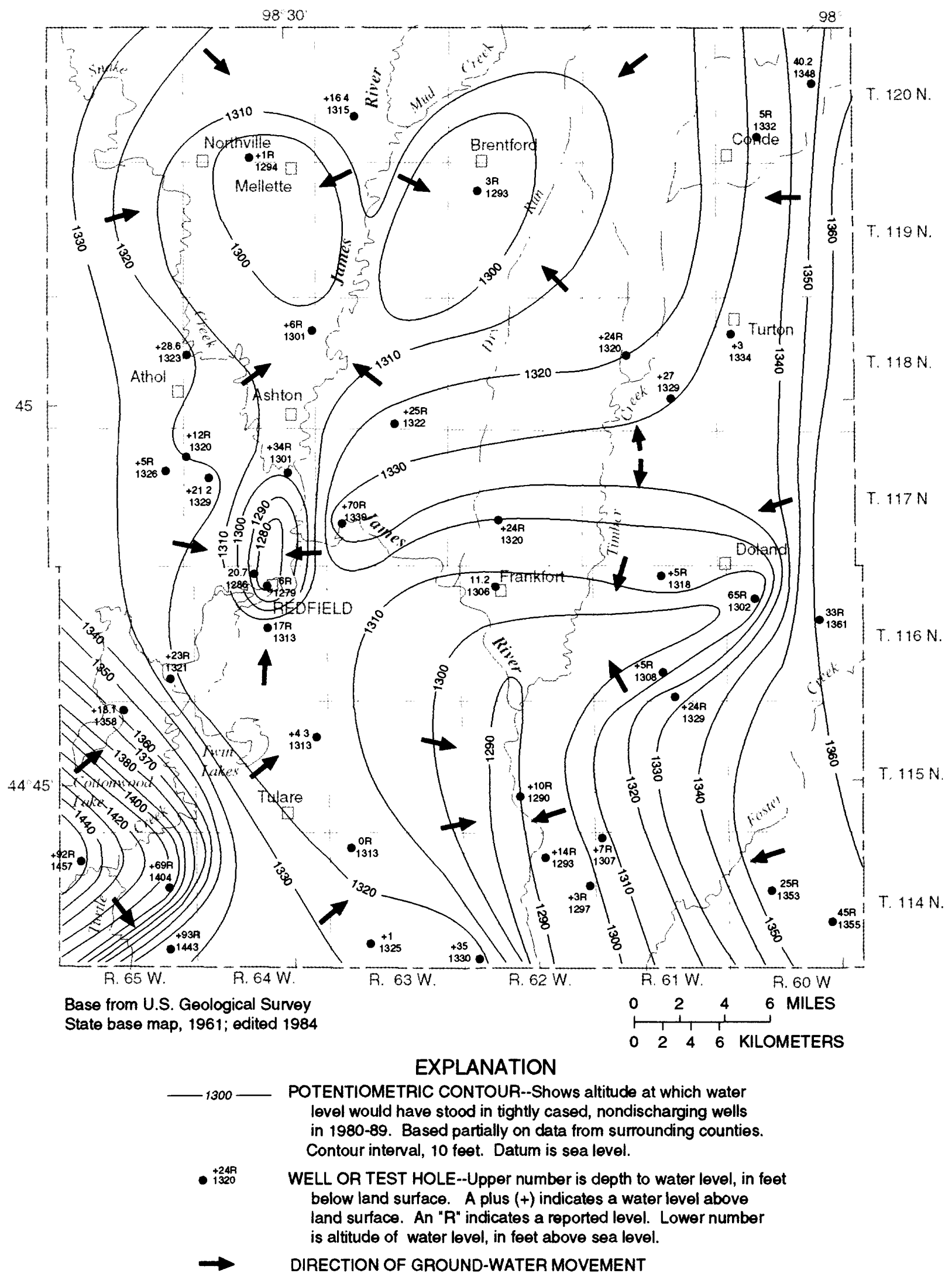

Figure 21. Potentiometric contours of the Dakota aquifer, 1980-89. 


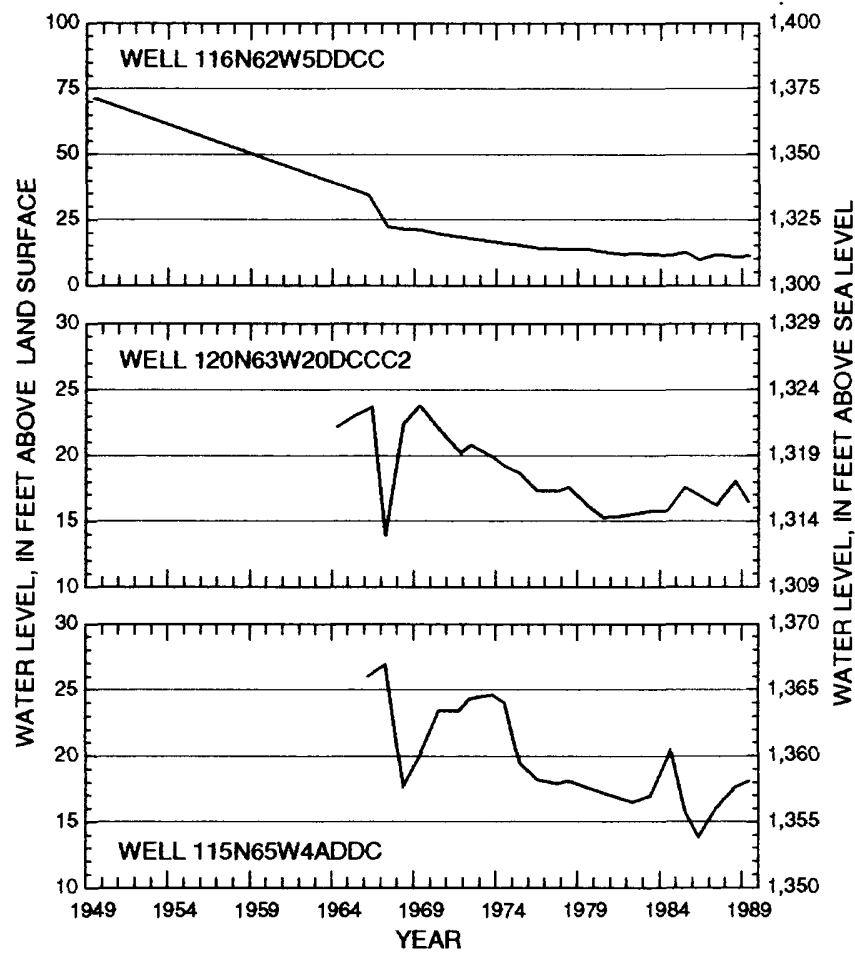

Figure 22. Water-level changes in the Dakota aquifer.

In the southwestern part of Spink County at wells 114N65W7ADAC, 14DDAA2, 26AA, and $35 \mathrm{AADD} 3$, the aquifer was penetrated at a depth of about 1,150 feet, an altitude of about 180 feet above sea level. The aquifer there is composed of as much as 60 feet of shaly, fine to medium sand that is very permeable. Initial artesian pressures of as much as 40 pounds per square inch and flows of as much as 60 gallons per minute through 2-inch casing were reported by drillers. Yields have since declined as a result of a decrease in pressure.

\section{Minnelusa Aquifer}

The extent of the Minnelusa aquifer in Spink County is unknown. The aquifer was penetrated in one water well at a depth of 1,265 feet in the northwestern part of Spink County. The location of the well, which was drilled in 1901 for Ezra Martin by Peter Norbeck, is believed to be 120N64W20BD. The top of the Minnelusa Formation is estimated to be at an altitude of 32 feet above sea level at that location. The bottom of the Minnelusa was reported to lie on very hard rock, probably granite, at an altitude of 403 feet below sea level. The driller's log starting at the top of the Minnelusa Formation, reported 30 feet of "caprock," 230 feet of "shale with water from grav- elly clay," 75 feet of "layers of sandrock," 100 feet of "sandstone," and 4 feet of "hard rock." The initial flow reported was 135 gallons per minute through 5 1/2-inch casing.

\section{Ground-Water Quality}

\section{Water Quality in Glacial Aquifers}

The chemical quality of water in aquifers in glacial drift deposits varies widely, both within and between aquifers and, in many places, with depth at a given time. Generally, water in the glacial aquifers is very hard, ranging from 84 to $3,700 \mathrm{mg} / \mathrm{L}$. Patterns in water type are not obvious, but some general observations are apparent. Calcium, magnesium, and sodium tend to be co-dominant for many glacial aquifer samples, although calcium is clearly the dominant cation for most samples from the Tulare aquifer. Sulfate tends to be the dominant anion, although bicarbonate is dominant or co-dominant in many samples. Concentrations of dissolved solids in water samples collected during 1962-91 from aquifers in drift ranged from $151 \mathrm{mg} / \mathrm{L}$ at a site in the northeastern part of the county to $9,610 \mathrm{mg} / \mathrm{L}$ at a site in the central part of the county. Concentrations of dissolved solids tend to be large where aquifers are thin or have low permeability, as in T. 116 N., R. 63 W., T. 117 N., R. 63 W., and T. 120 N., R. 63 W. and R. 64 W. Concentrations tended to decrease with increasing well depth in many areas. Concentrations of sodium generally tended to be highest in areas where the concentrations of dissolved solids exceeded 2,000 mg/L (fig. 23). Sodium concentrations also exceeded $400 \mathrm{mg} / \mathrm{L}$ near the James River in T. 115 N., R. 62 W., where the Niobrara aquifer discharges sodium-rich water into aquifers in the drift. A summary of chemical analyses of ground water, based on data stored in the USGS WATSTORE water-quality file, is presented in table 8.

Water samples collected from wells tapping surficial aquifers in Spink County did not exceed the Maximum Contaminant Level ${ }^{1}$ (MCL) established by

\footnotetext{
${ }^{1}$ Primary Maximum Contaminant Levels are established for contaminants that, if present in drinking water, may cause adverse human health effects; MCL's are enforceable health-based standards. Drinking-water standards established by the State of South Dakota correspond directly with EPA regulations. Federal law requires that drinking-water standards established by the States cannot be less stringent than those established by EPA; the South Dakota Legislature has, in turn, mandated that State drinkingwater standards cannot be more stringent than the EPA regulations.
} 


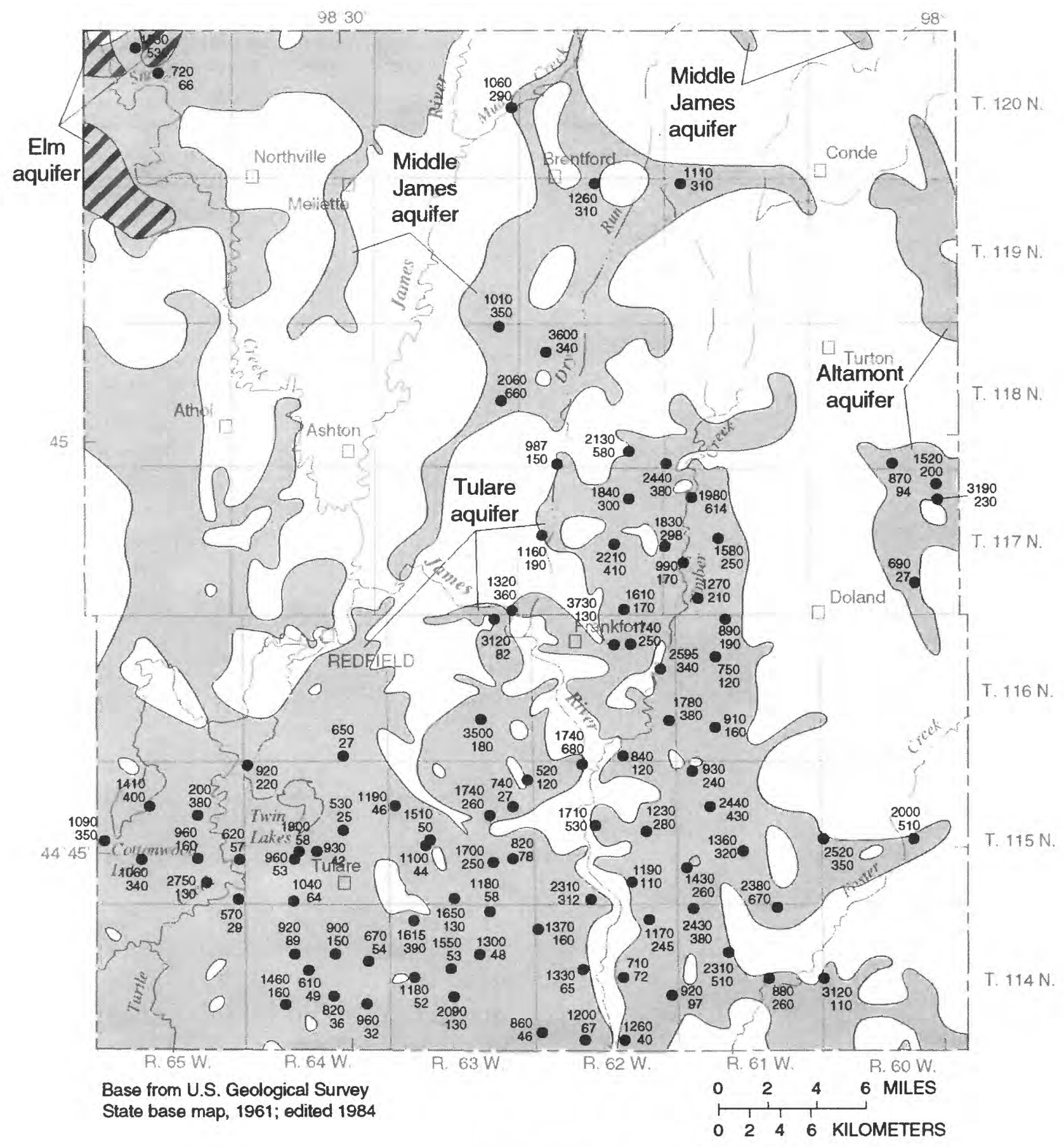

EXPLANATION

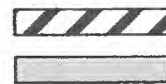

APPROXIMATE AREA UNDERLAIN BY ELM AQUIFER

APPROXIMATE AREA UNDERLAIN BY TULARE, MIDDLE JAMES, AND ALTAMONT AQUIFERS

WELL--Upper number is dissolved-solids concentration;

lower number is sodium concentration, both in milligrams per liter (from DENR laboratory analyses)

Figure 23. Dissolved-solids and sodium concentrations in water from selected aquifers in glacial deposits, 1989-90. 
Table 8. Summary of chemical analyses of ground water, 1937-91

[Results based on data stored in USGS WATSTORE water-quality file. Results in milligrams per liter except as indicated. One milligram per liter $(\mathrm{mg} / \mathrm{L})$ is approximately equal to one part per million. One microgram per liter $(\mu \mathrm{g} / \mathrm{L})$ is equal to one part per billion; $\mu \mathrm{S} / \mathrm{cm}$, microsiemens per centimeter at $25^{\circ} \mathrm{Celsius;}$ pci/L, picocurie per liter; --, not analyzed or not determined; <, less than indicated detection limit; ND, specifically analyzed for but not detected, and detection limit unknown]

\begin{tabular}{|c|c|c|c|c|}
\hline \multirow{2}{*}{$\begin{array}{l}\text { Property or } \\
\text { dissolved constituent }\end{array}$} & \multicolumn{4}{|c|}{ Tulare aquifer } \\
\hline & Number of samples & Median & Minimum & Maximum \\
\hline Specific conductance $(\mu \mathrm{S} / \mathrm{cm})$ & 267 & 1,380 & 410 & 5,250 \\
\hline pH (standard units) & 254 & 7.6 & 5.8 & 9.7 \\
\hline Carbon dioxide & 209 & 19 & 0.1 & 155 \\
\hline Hardness, as $\mathrm{CaCO}_{3}$ & 270 & 500 & 100 & 2,500 \\
\hline Solids, residue at $180^{\circ} \mathrm{C}$ & 111 & 1,000 & 192 & 5,280 \\
\hline Solids, sum of constituents & 233 & 933 & 245 & 4,430 \\
\hline Calcium & 272 & 130 & 16 & 530 \\
\hline Magnesium & 270 & 42 & 6 & 370 \\
\hline Sodium & 270 & 120 & 9.1 & 810 \\
\hline Potassium & 252 & 11 & 1.1 & 29 \\
\hline Bicarbonate & 211 & 450 & 8 & 740 \\
\hline Sulfate & 253 & 340 & 20 & 2,900 \\
\hline Chloride & 272 & 32 & 2 & 770 \\
\hline Fluoride & 46 & 0.2 & 0.01 & 1.3 \\
\hline Silica & 32 & 22 & 0.7 & 30 \\
\hline Nitrogen, nitrate ${ }^{1}$ & 109 & 0.3 & $<0.1$ & 32.5 \\
\hline Phosphorus, orthophosphate & 9 & $<0.01$ & $<0.01$ & 0.04 \\
\hline Aluminum $(\mu \mathrm{g} / \mathrm{L})$ & 1 & 10 & 10 & 10 \\
\hline Arsenic $(\mu \mathrm{g} / \mathrm{L})$ & 1 & 2 & 2 & 2 \\
\hline Barium $(\mu \mathrm{g} / \mathrm{L})$ & 1 & 20 & 20 & 20 \\
\hline Boron $(\mu \mathrm{g} / \mathrm{L})$ & 92 & 390 & ND & 2,700 \\
\hline Cadmium $(\mu \mathrm{g} / \mathrm{L})$ & 1 & $<1$ & $<1$ & $<1$ \\
\hline Chromium $(\mu \mathrm{g} / \mathrm{L})$ & 1 & 2 & 2 & 2 \\
\hline Cobalt $(\mu \mathrm{g} / \mathrm{L})$ & 1 & $<1$ & $<1$ & $<1$ \\
\hline Copper $(\mu \mathrm{g} / \mathrm{L})$ & 1 & $<1$ & $<1$ & $<1$ \\
\hline Iron $(\mu \mathrm{g} / \mathrm{L})$ & 111 & 710 & ND & 10,600 \\
\hline Lead $(\mu \mathrm{g} / \mathrm{L})$ & 1 & $<1$ & $<1$ & $<1$ \\
\hline Lithium $(\mu \mathrm{g} / \mathrm{L})$ & 1 & 120 & 120 & 120 \\
\hline Manganese $(\mu \mathrm{g} / \mathrm{L})$ & 46 & 930 & ND & 2,800 \\
\hline Mercury $(\mu \mathrm{g} / \mathrm{L})$ & 1 & $<0.1$ & $<0.1$ & $<0.1$ \\
\hline Molybdenum $(\mu \mathrm{g} / \mathrm{L})$ & 1 & 3 & 3 & 3 \\
\hline Nickel $(\mu \mathrm{g} / \mathrm{L})$ & 1 & $<1$ & $<1$ & $<1$ \\
\hline Selenium $(\mu \mathrm{g} / \mathrm{L})$ & 2 & $<1$ & $<1$ & $<1$ \\
\hline Silver $(\mu \mathrm{g} / \mathrm{L})$ & 1 & $<1$ & $<1$ & $<1$ \\
\hline Strontium $(\mu \mathrm{g} / \mathrm{L})$ & 1 & 2,100 & 2,100 & 2,100 \\
\hline Vanadium $(\mu \mathrm{g} / \mathrm{L})$ & 1 & 1 & 1 & 1 \\
\hline Zinc $(\mu g / L)$ & 1 & 8 & 8 & 8 \\
\hline Radium-226 (pci/L) & 0 & - & -- & -- \\
\hline Thorium $(\mu \mathrm{g} / \mathrm{L})$ & 0 & -- & - & -- \\
\hline Uranium $(\mu \mathrm{g} / \mathrm{L})$ & 0 & -- & -- & - \\
\hline
\end{tabular}


Table 8. Summary of chemical analyses of ground water, 1937-91-Continued

\begin{tabular}{|c|c|c|c|c|}
\hline \multirow{2}{*}{$\begin{array}{c}\text { Property or } \\
\text { dissolved constituent }\end{array}$} & \multicolumn{4}{|c|}{ Elm aquifer } \\
\hline & Number of samples & Median & Minimum & Maximum \\
\hline Specific conductance $(\mu \mathrm{S} / \mathrm{cm})$ & 6 & 1,250 & 577 & 2,540 \\
\hline pH (standard units) & 6 & 7.4 & 7.2 & 9.7 \\
\hline Carbon dioxide & 5 & 19 & 0.2 & 45 \\
\hline Hardness, as $\mathrm{CaCO}_{3}$ & 6 & 410 & 230 & 950 \\
\hline Solids, residue at $180^{\circ} \mathrm{C}$ & 0 & -- & -- & -- \\
\hline Solids, sum of constituents & 5 & 460 & 309 & 1,090 \\
\hline Calcium & 6 & 110 & 26 & 230 \\
\hline Magnesium & 6 & 45 & 18 & 91 \\
\hline Sodium & 6 & 110 & 10 & 150 \\
\hline Potassium & 5 & 15 & 4 & 23 \\
\hline Bicarbonate & 5 & 430 & 280 & 470 \\
\hline Sulfate & 6 & 180 & 24 & 480 \\
\hline Chloride & 6 & 38 & 12 & 320 \\
\hline Fluoride & 0 & -- & -. & -- \\
\hline Silica & 0 & -- & -- & -- \\
\hline Nitrogen, nitrate ${ }^{1}$ & 0 & -- & -- & -- \\
\hline Phosphorus, orthophosphate & 0 & -- & -- & -- \\
\hline Aluminum $(\mu \mathrm{g} / \mathrm{L})$ & 0 & -- & -- & -- \\
\hline Arsenic $(\mu \mathrm{g} / \mathrm{L})$ & 0 & -- & $\cdots$ & -- \\
\hline Barium $(\mu \mathrm{g} / \mathrm{L})$ & 0 & -- & -- & -- \\
\hline Boron $(\mu \mathrm{g} / \mathrm{L})$ & 0 & -- & - & -- \\
\hline Cadmium $\mu \mathrm{g} / \mathrm{L}$ ) & 0 & -- & -- & -- \\
\hline Chromium $(\mu \mathrm{g} / \mathrm{L})$ & 0 & -- & -- & -- \\
\hline Cobalt $(\mu \mathrm{g} / \mathrm{L})$ & 0 & -- & -- & -- \\
\hline Copper $(\mu \mathrm{g} / \mathrm{L})$ & 0 & - & -- & -- \\
\hline Iron $(\mu \mathrm{g} / \mathrm{L})$ & 0 & -- & -- & -- \\
\hline Lead $(\mu \mathrm{g} / \mathrm{L})$ & 0 & -- & -- & -- \\
\hline Lithium $(\mu \mathrm{g} / \mathrm{L})$ & 0 & -- & -- & -- \\
\hline Manganese $(\mu \mathrm{g} / \mathrm{L})$ & 0 & - & -- & -- \\
\hline Mercury $(\mu \mathrm{g} / \mathrm{L})$ & 0 & - & -- & -- \\
\hline Molybdenum $(\mu \mathrm{g} / \mathrm{L})$ & 0 & - & -- & -- \\
\hline Nickel $(\mu \mathrm{g} / \mathrm{L})$ & 0 & -- & -- & -- \\
\hline Selenium $(\mu \mathrm{g} / \mathrm{L})$ & 0 & -- & -- & -- \\
\hline Silver $(\mu \mathrm{g} / \mathrm{L})$ & 0 & -- & -- & -- \\
\hline Strontium $(\mu \mathrm{g} / \mathrm{L})$ & 0 & -- & -- & -- \\
\hline Vanadium $(\mu \mathrm{g} / \mathrm{L})$ & 0 & - & -- & -- \\
\hline $\operatorname{Zinc}(\mu \mathrm{g} / \mathrm{L})$ & 0 & -- & -. & -- \\
\hline Radium-226 (pci/L) & 0 & -- & -- & -- \\
\hline Thorium $(\mu \mathrm{g} / \mathrm{L})$ & 0 & -- & -- & -- \\
\hline Uranium $(\mu \mathrm{g} / \mathrm{L})$ & 0 & -- & -- & -- \\
\hline
\end{tabular}


Table 8. Summary of chemical analyses of ground water, 1937-91-Continued

\begin{tabular}{|c|c|c|c|c|}
\hline \multirow{2}{*}{$\begin{array}{l}\text { Property or } \\
\text { dlssolved constituent }\end{array}$} & \multicolumn{4}{|c|}{ Altamont aquifer } \\
\hline & Number of samples & Median & Minimum & Maximum \\
\hline Specific conductance $(\mu \mathrm{S} / \mathrm{cm})$ & 11 & 1,510 & 810 & 3,980 \\
\hline pH (standard units) & 12 & 7.4 & 5.6 & 7.9 \\
\hline Carbon dioxide & 7 & 26 & 3.2 & 47 \\
\hline Hardness, as $\mathrm{CaCO}_{3}$ & 12 & 630 & 280 & 1,300 \\
\hline Solids, residue at $180^{\circ} \mathrm{C}$ & 1 & 1,060 & 1,060 & 1,060 \\
\hline Solids, sum of constituents & 7 & 1,000 & 502 & 1,410 \\
\hline Calcium & 12 & 150 & 73 & 240 \\
\hline Magnesium & 12 & 59 & 23 & 220 \\
\hline Sodium & 12 & 170 & 63 & 510 \\
\hline Potassium & 11 & 12 & 5 & 20 \\
\hline Bicarbonate & 8 & 327 & 142 & 550 \\
\hline Sulfate & 8 & 530 & 91 & 2,000 \\
\hline Chloride & 12 & 22 & 3 & 143 \\
\hline Fluoride & 0 & -- & -- & -- \\
\hline Silica & 1 & 10 & 10 & 10 \\
\hline Nitrogen, nitrate ${ }^{1}$ & 1 & 0.22 & 0.22 & 0.22 \\
\hline Phosphorus, orthophosphate & 0 & -- & -- & -- \\
\hline Aluminum $(\mu \mathrm{g} / \mathrm{L})$ & 1 & $<10$ & $<10$ & $<10$ \\
\hline Arsenic $(\mu \mathrm{g} / \mathrm{L})$ & 1 & $<1$ & $<1$ & $<1$ \\
\hline Barium $(\mu \mathrm{g} / \mathrm{L})$ & 1 & 5 & 5 & 5 \\
\hline Boron $\mu \mathrm{g} / \mathrm{L})$ & 2 & 500 & 350 & 650 \\
\hline Cadmium $(\mu \mathrm{g} / \mathrm{L})$ & 0 & -. & -- & -- \\
\hline Chromium $(\mu \mathrm{g} / \mathrm{L})$ & 1 & $<4$ & $<4$ & $<4$ \\
\hline Cobalt $(\mu \mathrm{g} / \mathrm{L})$ & 1 & $<2$ & $<2$ & $<2$ \\
\hline Copper $(\mu \mathrm{g} / \mathrm{L})$ & 1 & $<2$ & $<2$ & $<2$ \\
\hline Iron $(\mu \mathrm{g} / \mathrm{L})$ & 2 & 330 & 12 & 640 \\
\hline Lead $(\mu \mathrm{g} / \mathrm{L})$ & 0 & - & -- & -- \\
\hline Lithium $(\mu \mathrm{g} / \mathrm{L})$ & 1 & 290 & 290 & 290 \\
\hline Manganese $(\mu \mathrm{g} / \mathrm{L})$ & 1 & 83 & 83 & 83 \\
\hline Mercury $(\mu \mathrm{g} / \mathrm{L})$ & 0 & -- & -- & -- \\
\hline Molybdenum $(\mu \mathrm{g} / \mathrm{L})$ & 1 & $<4$ & $<4$ & $<4$ \\
\hline Nickel $(\mu \mathrm{g} / \mathrm{L})$ & 1 & 6 & 6 & 6 \\
\hline Selenium $(\mu \mathrm{g} / \mathrm{L})$ & 1 & ND & ND & ND \\
\hline Silver $(\mu \mathrm{g} / \mathrm{L})$ & 1 & $<2$ & $<2$ & $<2$ \\
\hline Strontium $(\mu \mathrm{g} / \mathrm{L})$ & 1 & 2,600 & 2,600 & 2,600 \\
\hline Vanadium $(\mu \mathrm{g} / \mathrm{L})$ & 1 & $<4$ & $<4$ & $<4$ \\
\hline $\operatorname{Zinc}(\mu \mathrm{g} / \mathrm{L})$ & 1 & 10 & 10 & 10 \\
\hline Radium-226 (pci/L) & 0 & -- & -- & -- \\
\hline Thorium $(\mu \mathrm{g} / \mathrm{L})$ & 1 & 8 & 8 & 8 \\
\hline Uranium $(\mu \mathrm{g} / \mathrm{L})$ & 1 & 8.5 & 8.5 & 8.5 \\
\hline
\end{tabular}


Tabie 8. Summary of chemical analyses of ground water, 1937-91-Continued

\begin{tabular}{|c|c|c|c|c|}
\hline \multirow{2}{*}{$\begin{array}{c}\text { Property or } \\
\text { dissolved constituent }\end{array}$} & \multicolumn{4}{|c|}{ Middle James aquifer } \\
\hline & Number of samples & Median & Minimum & Maximum \\
\hline Specific conductance $(\mu \mathrm{S} / \mathrm{cm})$ & 8 & 1,810 & 594 & 3,930 \\
\hline $\mathrm{pH}$ (standard units) & 8 & 7.6 & 7.0 & 8.0 \\
\hline Carbon dioxide & 4 & 20 & 5 & 70 \\
\hline Hardness, as $\mathrm{CaCO}_{3}$ & 8 & 240 & 110 & 1,910 \\
\hline Solids, residue at $180^{\circ} \mathrm{C}$ & 0 & -- & -- & -- \\
\hline Solids, sum of constituents & 8 & 1,040 & 349 & 3,480 \\
\hline Calcium & 8 & 68 & 28 & 500 \\
\hline Magnesium & 8 & 22 & 8.8 & 160 \\
\hline Sodium & 8 & 300 & 10 & 660 \\
\hline Potassium & 8 & 10 & 7.9 & 52 \\
\hline Bicarbonate & 4 & 390 & 310 & 520 \\
\hline Sulfate & 8 & 180 & 13 & 2,200 \\
\hline Chloride & 8 & 130 & 25 & 370 \\
\hline Fluoride & 5 & 0.3 & 0.2 & 0.6 \\
\hline Silica & 5 & 27 & 25 & 30 \\
\hline Nitrogen, nitrate ${ }^{1}$ & 0 & -- & -- & -- \\
\hline Phosphorus, orthophosphate & 2 & 0.02 & 0.02 & 0.02 \\
\hline Aluminum $(\mu \mathrm{g} / \mathrm{L})$ & 0 & -- & -- & -- \\
\hline Arsenic $(\mu \mathrm{g} / \mathrm{L})$ & 0 & -. &.- & -- \\
\hline Barium $(\mu \mathrm{g} / \mathrm{L})$ & 0 & -. & -- & -- \\
\hline Boron $(\mu \mathrm{g} / \mathrm{L})$ & 0 & -- & -- & -- \\
\hline Cadmium $(\mu \mathrm{g} / \mathrm{L})$ & 0 & -- & -- & -. \\
\hline Chromium $(\mu \mathrm{g} / \mathrm{L})$ & 0 & $-\cdot$ & -- & -- \\
\hline Cobalt $(\mu g / L)$ & 0 & -- & -- & -- \\
\hline Copper $(\mu \mathrm{g} / \mathrm{L})$ & 0 & -. & -- & -- \\
\hline Iron $(\mu \mathrm{g} / \mathrm{L})$ & 5 & 290 & 20 & 370 \\
\hline Lead $(\mu \mathrm{g} / \mathrm{L})$ & 0 & -- & -- & -- \\
\hline Lithium $(\mu \mathrm{g} / \mathrm{L})$ & 0 & -- & -- & -- \\
\hline Manganese $(\mu \mathrm{g} / \mathrm{L})$ & 4 & 430 & 100 & 1,200 \\
\hline Mercury $(\mu \mathrm{g} / \mathrm{L})$ & 0 & -- & - & -- \\
\hline Molybdenum $(\mu \mathrm{g} / \mathrm{L})$ & 0 &.- & -- & -- \\
\hline Nickel $(\mu \mathrm{g} / \mathrm{L})$ & 0 & -- & - & -- \\
\hline Selenium $(\mu \mathrm{g} / \mathrm{L})$ & 2 & $<1$ & $<1$ & $<1$ \\
\hline Silver $(\mu \mathrm{g} / \mathrm{L})$ & 0 & -- & -- & -- \\
\hline Strontium $(\mu \mathrm{g} / \mathrm{L})$ & 0 & -- & -- & -- \\
\hline Vanadium $(\mu \mathrm{g} / \mathrm{L})$ & 0 & -- & -- & -- \\
\hline $\operatorname{Zinc}(\mu \mathrm{g} / \mathrm{L})$ & 0 & -- & - & -- \\
\hline Radium-226 (pci/L) & 0 & -- & -. & -- \\
\hline Thorium $(\mu \mathrm{g} / \mathrm{L})$ & 0 & -- & -- & -- \\
\hline Uranium $(\mu \mathrm{g} / \mathrm{L})$ & 0 & -- & -- & $\cdots$ \\
\hline
\end{tabular}


Table 8. Summary of chemical analyses of ground water, 1937-91-Continued

\begin{tabular}{|c|c|c|c|c|}
\hline \multirow{2}{*}{$\begin{array}{l}\text { Property or } \\
\text { dissolved constituent }\end{array}$} & \multicolumn{4}{|c|}{ Deep James aquifer } \\
\hline & Number of samples & Median & Minimum & Maximum \\
\hline Specific conductance $(\mu \mathrm{S} / \mathrm{cm})$ & 4 & 1,640 & 1,370 & 2,740 \\
\hline pH (standard units) & 4 & 7.3 & 7.1 & 7.8 \\
\hline Carbon dioxide & 1 & 6 & 6 & 6 \\
\hline Hardness, as $\mathrm{CaCO}_{3}$ & 4 & 460 & 280 & 770 \\
\hline Solids, residue at $180^{\circ} \mathrm{C}$ & 1 & 1,200 & 1,200 & 1,200 \\
\hline Solids, sum of constituents & 3 & 1,160 & 987 & 1,170 \\
\hline Calcium & 4 & 130 & 77 & 200 \\
\hline Magnesium & 4 & 37 & 22 & 69 \\
\hline Sodium & 4 & 170 & 71 & 530 \\
\hline Potassium & 4 & 11 & 10 & 12 \\
\hline Bicarbonate & 1 & 220 & 220 & 220 \\
\hline Sulfate & 4 & 490 & 330 & 650 \\
\hline Chloride & 4 & 98 & 62 & 230 \\
\hline Fluoride & 3 & 0.4 & 0.2 & 0.8 \\
\hline Silica & 3 & 30 & 28 & 32 \\
\hline Nitrogen, nitrate ${ }^{1}$ & 4 & -- & $<0.05$ & 1.1 \\
\hline Phosphorus, orthophosphate & 2 & $<0.01$ & $<0.01$ & $<0.01$ \\
\hline Aluminum $(\mu \mathrm{g} / \mathrm{L})$ & 1 & 10 & 10 & 10 \\
\hline Arsenic $(\mu \mathrm{g} / \mathrm{L})$ & 1 & $<1$ & $<1$ & $<1$ \\
\hline Barium $(\mu \mathrm{g} / \mathrm{L})$ & 1 & $<100$ & $<100$ & $<100$ \\
\hline Boron $(\mu \mathrm{g} / \mathrm{L})$ & 2 & 1,600 & 1,300 & 1,900 \\
\hline Cadmium $(\mu \mathrm{g} / \mathrm{L})$ & 1 & $<1$ & $<1$ & $<1$ \\
\hline Chromium $(\mu \mathrm{g} / \mathrm{L})$ & 1 & $<1$ & $<1$ & $<1$ \\
\hline Cobalt $(\mu \mathrm{g} / \mathrm{L})$ & 1 & $<1$ & $<1$ & $<1$ \\
\hline Copper $(\mu \mathrm{g} / \mathrm{L})$ & 1 & $<1$ & $<1$ & $<1$ \\
\hline Iron $(\mu \mathrm{g} / \mathrm{L})$ & 4 & 1,300 & 860 & 1,800 \\
\hline Lead $(\mu \mathrm{g} / \mathrm{L})$ & 1 & 1 & 1 & 1 \\
\hline Lithium $(\mu \mathrm{g} / \mathrm{L})$ & 1 & 130 & 130 & 130 \\
\hline Manganese ( $\mu g / L)$ & 3 & 430 & 360 & 460 \\
\hline Mercury $(\mu g / L)$ & 1 & 0.2 & 0.2 & 0.2 \\
\hline Molybdenum $(\mu \mathrm{g} / \mathrm{L})$ & 1 & $<1$ & $<1$ & $<1$ \\
\hline Nickel $(\mu \mathrm{g} / \mathrm{L})$ & 1 & $<1$ & $<1$ & $<1$ \\
\hline Selenium $(\mu \mathrm{g} / \mathrm{L})$ & 2 & $<1$ & $<1$ & $<1$ \\
\hline Silver $(\mu \mathrm{g} / \mathrm{L})$ & 1 & $<1$ & $<1$ & $<1$ \\
\hline Strontium $(\mu \mathrm{g} / \mathrm{L})$ & 1 & 910 & 910 & 910 \\
\hline Vanadium $(\mu \mathrm{g} / \mathrm{L})$ & 1 & 4 & 4 & 4 \\
\hline $\operatorname{Zinc}(\mu g / L)$ & 1 & $<10$ & $<10$ & $<10$ \\
\hline Radium-226 (pci/L) & 0 & -- & -- & -- \\
\hline Thorium $(\mu \mathrm{g} / L)$ & 0 & -- & -- & -- \\
\hline Uranium $(\mu \mathrm{g} / \mathrm{L})$ & 0 & -- & -- & -. \\
\hline
\end{tabular}


Tabie 8. Summary of chemical analyses of ground water, 1937-91-Continued

\begin{tabular}{|c|c|c|c|c|}
\hline \multirow{2}{*}{$\begin{array}{c}\text { Property or } \\
\text { dissolved constituents }\end{array}$} & \multicolumn{4}{|c|}{ Minor aquifers in glacial drift } \\
\hline & Number of samples & Median & Minimum & Maximum \\
\hline Specific conductance $(\mu \mathrm{S} / \mathrm{cm})$ & 125 & 2,100 & 240 & 11,000 \\
\hline $\mathrm{pH}$ (standard units) & 126 & 7.4 & 5.7 & 10.2 \\
\hline Carbon dioxide & 116 & 32 & 3.2 & 222 \\
\hline Hardness, as $\mathrm{CaCO}_{3}$ & 126 & 850 & 84 & 3,700 \\
\hline Solids, residue at $180^{\circ} \mathrm{C}$ & 16 & 1,650 & 301 & 6,180 \\
\hline Solids, sum of constituents & 122 & 1,580 & 151 & 9,610 \\
\hline Calcium & 126 & 190 & 25 & 610 \\
\hline Magnesium & 126 & 76 & 5.3 & 650 \\
\hline Sodium & 126 & 152 & 16 & 1,900 \\
\hline Potassium & 123 & 10 & 5.2 & 150 \\
\hline Bicarbonate & 122 & 440 & 130 & 1,000 \\
\hline Sulfate & 125 & 870 & 14 & 6,300 \\
\hline Chloride & 125 & 50 & ND & 820 \\
\hline Fluoride & 106 & 0.4 & ND & 1.4 \\
\hline Silica & 107 & 27 & 0.4 & 34 \\
\hline Nitrogen, nitrate ${ }^{1}$ & 112 & 0.20 & $<0.1$ & 34 \\
\hline Phosphorus, orthophosphate & 100 & 0.04 & $<0.01$ & 0.22 \\
\hline Aluminum $(\mu \mathrm{g} / \mathrm{L})$ & 2 & 20 & 20 & 20 \\
\hline Arsenic $(\mu \mathrm{g} / \mathrm{L})$ & 2 & $<0.5$ & $<0.5$ & $<0.5$ \\
\hline Barium $(\mu \mathrm{g} / \mathrm{L})$ & 2 & 6 & 2 & 10 \\
\hline Boron $(\mu \mathrm{g} / \mathrm{L})$ & 114 & 540 & 80 & 2,400 \\
\hline Cadmium $(\mu \mathrm{g} / \mathrm{L})$ & 0 & -. & -- & - \\
\hline Chromium $(\mu \mathrm{g} / \mathrm{L})$ & 2 & $<4$ & $<4$ & $<4$ \\
\hline Cobalt $(\mu \mathrm{g} / \mathrm{L})$ & 2 & -- & $<2$ & 2 \\
\hline Copper $(\mu \mathrm{g} / \mathrm{L})$ & 2 & 6 & 4 & 8 \\
\hline Iron $(\mu \mathrm{g} / \mathrm{L})$ & 111 & 80 & $<10$ & 6,200 \\
\hline Lead $(\mu \mathrm{g} / \mathrm{L})$ & 0 & -- & -- & -- \\
\hline Lithium $(\mu \mathrm{g} / \mathrm{L})$ & 2 & 215 & 130 & 400 \\
\hline Manganese $(\mu \mathrm{g} / \mathrm{L})$ & 34 & 900 & $<10$ & 3,700 \\
\hline Mercury $(\mu g / L)$ & 0 & -- & -- & -- \\
\hline Molybdenum ( $\mu \mathrm{g} / \mathrm{L})$ & 2 & $<4$ & $<4$ & $<4$ \\
\hline Nickel $(\mu \mathrm{g} / \mathrm{L})$ & 2 & $<4$ & $<4$ & $<4$ \\
\hline Selenium $(\mu \mathrm{g} / \mathrm{L})$ & 2 & $<0.2$ & $<0.2$ & $<0.2$ \\
\hline Silver $(\mu \mathrm{g} / \mathrm{L})$ & 2 & 3.5 & 3 & 4 \\
\hline Strontium $(\mu \mathrm{g} / \mathrm{L})$ & 2 & 1,800 & 1,700 & 1,900 \\
\hline Vanadium $(\mu \mathrm{g} / \mathrm{L})$ & 2 & $<4$ & $<4$ & $<4$ \\
\hline $\operatorname{Zinc}(\mu \mathrm{g} / \mathrm{L})$ & 2 & 23 & 6 & 40 \\
\hline Radium-226 (pci/L) & 0 & -- & -- & -- \\
\hline Thorium $(\mu \mathrm{g} / \mathrm{L})$ & 2 & -- & $<5$ & 6 \\
\hline Uranium $(\mu \mathrm{g} / \mathrm{L})$ & 2 & 13 & II & 15 \\
\hline
\end{tabular}


Table 8. Summary of chemical analyses of ground water, 1937-91-Continued

\begin{tabular}{|c|c|c|c|c|}
\hline \multirow{2}{*}{$\begin{array}{c}\text { Property or } \\
\text { dissolved constituent }\end{array}$} & \multicolumn{4}{|c|}{ Dakota aquifer } \\
\hline & Number of samples & Median & Minimum & Maximum \\
\hline Specific conductance $(\mu \mathrm{S} / \mathrm{cm})$ & 40 & 3,100 & 2,500 & 3,600 \\
\hline pH (standard units) & 72 & 7.9 & 7.0 & 8.5 \\
\hline Carbon dioxide & 55 & 5.9 & 1.7 & 22 \\
\hline Hardness, as $\mathrm{CaCO}_{3}$ & 98 & 100 & 10 & 1,400 \\
\hline Solids, residue at $180^{\circ} \mathrm{C}$ & 86 & 2,170 & 1,940 & 2,910 \\
\hline Solids, sum of constituents & 70 & 2,110 & 1,620 & 2,670 \\
\hline Calcium & 99 & 28 & 2.9 & 330 \\
\hline Magnesium & 99 & 7.0 & ND & 160 \\
\hline Sodium & 77 & 670 & 90 & 960 \\
\hline Potassium & 71 & 12 & 2.9 & 28 \\
\hline Bicarbonate & 74 & 270 & 144 & 530 \\
\hline Sulfate & 98 & 1,100 & 530 & 1,300 \\
\hline Chloride & 98 & 200 & 66 & 840 \\
\hline Fluoride & 98 & 2.7 & ND & 4.5 \\
\hline Silica & 25 & 10 & 2 & 13 \\
\hline Nitrogen, nitrate ${ }^{1}$ & 83 & $<0.1$ & $<0.1$ & 8.8 \\
\hline Phosphorus, orthophosphate & 12 & 0.02 & $<0.01$ & 0.06 \\
\hline Aluminum $(\mu \mathrm{g} / \mathrm{L})$ & 2 & 10 & 10 & 10 \\
\hline Arsenic $(\mu \mathrm{g} / \mathrm{L})$ & 13 & 2 & $<0.5$ & 7 \\
\hline Barium $(\mu \mathrm{g} / \mathrm{L})$ & 13 & 12 & 5 & 50 \\
\hline Boron $(\mu \mathrm{g} / \mathrm{L})$ & 6 & 3,000 & 770 & 3,200 \\
\hline Cadmium $(\mu \mathrm{g} / \mathrm{L})$ & 12 & 5 & $<1$ & 10 \\
\hline Chromium $(\mu g / L)$ & 13 & -- & $<1$ & 3 \\
\hline Cobalt $(\mu \mathrm{g} / \mathrm{L})$ & 2 & -- & $<2$ & 8 \\
\hline Copper $(\mu g / L)$ & 8 & 8 & 2 & 340 \\
\hline Iron $(\mu \mathrm{g} / \mathrm{L})$ & 94 & 500 & $<10$ & 6,200 \\
\hline Lead $(\mu \mathrm{g} / \mathrm{L})$ & 12 & -- & $<1$ & 36 \\
\hline Lithium $(\mu \mathrm{g} / \mathrm{L})$ & 2 & 90 & 70 & 100 \\
\hline Manganese $(\mu \mathrm{g} / \mathrm{L})$ & 76 & 50 & $<10$ & 110 \\
\hline Mercury $(\mu \mathrm{g} / \mathrm{L})$ & 12 & $<0.2$ & $<0.2$ & 0.2 \\
\hline Molybdenum $(\mu \mathrm{g} / \mathrm{L})$ & 2 & 22 & 4 & 39 \\
\hline Nickel $(\mu \mathrm{g} / \mathrm{L})$ & 2 & -- & $<4$ & 20 \\
\hline Selenium $(\mu g / L)$ & 16 & 3.1 & $<1$ & 19 \\
\hline Silver $(\mu \mathrm{g} / \mathrm{L})$ & 14 & 3 & $<1$ & 20 \\
\hline Strontium $(\mu \mathrm{g} / \mathrm{L})$ & 2 & 1,700 & 490 & 2,900 \\
\hline Vanadium $(\mu \mathrm{g} / \mathrm{L})$ & 2 & -. & $<4$ & 4 \\
\hline Zinc $(\mu \mathrm{g} / \mathrm{L})$ & 8 & 60 & 5 & 10,000 \\
\hline Radium-226 (pci/L) & 1 & 1.2 & 1.2 & 1.2 \\
\hline Thorium $(\mu \mathrm{g} / \mathrm{L})$ & 2 & 5.5 & 5 & 6 \\
\hline Uranium $(\mu \mathrm{g} / \mathrm{L})$ & 3 & 0.2 & 0.1 & 2.8 \\
\hline
\end{tabular}

${ }^{1}$ Nitrate-nitrogen concentrations reported in this study were determined either as nitrate nitrogen alone, or as nitrite plus nitrate nitrogen. Spink County ground-water samples that were analyzed for nitrite nitrogen had very small concentrations; typically less than $0.01 \mathrm{mg} / \mathrm{L}$. Therefore, nitrate nitrogen and nitrite plus nitrate nitrogen concentrations in Spink County ground-water samples were considered essentially equivalent. 
the U.S. Environmental Protection Agency Primary Drinking-Water Regulations for any regulated constituent with the following exception: two samples out of 109 collected from the Tulare aquifer and one sample out of 112 collected from minor aquifers in glacial drift exceeded the EPA MCL for nitrate of $10 \mathrm{mg} / \mathrm{L}$ (U.S. Environmental Protection Agency, 1994a).

The median concentrations of dissolved solids and sulfate in water samples collected from the Tulare, Altamont, Middle James, and Deep James aquifers are near or exceed the EPA Secondary Maximum Contaminant Level $^{2}$ (SMCL) of $500 \mathrm{mg} / \mathrm{L}$ and $250 \mathrm{mg} / \mathrm{L}$, respectively (U.S. Environmental Protection Agency, 1994a). Also, the median concentrations of iron and manganese in water samples collected from the Tulare, Middle James, and Deep James aquifers are near or exceed the EPA SMCL of $300 \mu \mathrm{g} / \mathrm{L}$ and $50 \mu \mathrm{g} / \mathrm{L}$, respectively. Boron concentrations in water from the Deep James aquifer may exceed recommended limits for irrigation of boron-sensitive crops (U.S. Environmental Protection Agency, 1986).

\section{Water Quality in Bedrock Aquifers}

Most water in bedrock aquifers is slightly saline, soft to extremely hard, and of sodium sulfate or calcium magnesium sulfate type. Hardness is greatest in the deepest aquifers and may exceed $1,500 \mathrm{mg} / \mathrm{L}$ in water from the Minnelusa aquifer.

\section{Niobrara Aquifer}

Although only two samples exist in the USGS water-quality data base for the Niobrara aquifer in Spink County, these samples allow general observations about the water quality of the aquifer in Spink County when considered in conjunction with nine samples from the Niobrara aquifer in adjacent counties. Generally, the water of the Niobrara aquifer is soft, with sodium being strongly dominant among the cations. Sulfate generally is the most dominant anion, but chloride and bicarbonate may equal or exceed sulfate in dominance for some samples. Dissolvedsolids concentrations for two samples collected from the Niobrara aquifer in Spink County were 1,410 and

\footnotetext{
${ }^{2}$ Secondary Maximum Contaminant Levels are established for contaminants that can adversely affect the odor or appearance of water and result in discontinuation of use of the water; SMCL's are nonenforceable, generally non-health-based standards that are related to the aesthetics of water use.
}

$1,580 \mathrm{mg} / \mathrm{L}$. Samples collected from the Niobrara aquifer in adjacent counties also generally were about $1,500 \mathrm{mg} / \mathrm{L}$.

The large sodium concentration in the Niobrara aquifer makes the water unsuitable for irrigation use. Concentrations of dissolved solids and sulfate exceed EPA SMCL's of 500 and $250 \mu \mathrm{g} / \mathrm{L}$, respectively, and result in the water being only marginally suitable for human consumption. Excessive dissolved-solids concentrations in some locations may also render the water unsuitable for livestock consumption, although this generally would not be true. Iron and manganese concentrations in the two Spink County Niobrara aquifer samples did not exceed EPA SMCL's of $300 \mu \mathrm{g} / \mathrm{L}$, but a few of the samples for surrounding counties did; it is likely that iron and manganese concentrations in the Niobrara aquifer in Spink County are near or exceed EPA SMCL's at some locations. Water from the Niobrara may cause degradation of water quality in overlying or adjacent aquifers in the drift, where the Niobrara recharges aquifers that otherwise yield water of better quality.

\section{Dakota Aquifer}

Water from the Dakota aquifer generally is a slightly saline, soft to moderately hard, sodium sulfate type. Dissolved-solids (sum of constituents) concentrations in water samples collected during 1937-89 from the Dakota aquifer had a median value of $2,110 \mathrm{mg} / \mathrm{L}$ and ranged from 1,620 to $2,670 \mathrm{mg} / \mathrm{L}$ (table 8). Although the median hardness is $100 \mathrm{mg} / \mathrm{L}$ (moderately hard), the highest hardness was $1,400 \mathrm{mg} / \mathrm{L}$, and there were a few other samples with hardness exceeding $1,000 \mathrm{mg} / \mathrm{L}$; these levels represent extreme hardness and were found in samples from wells located in the southwestern part of the county (fig. 24). The extreme hardness found at some wells in this area probably is due to recharge of the aquifer by calcium magnesium sulfate type water from deeper aquifers that are under higher artesian pressure. A zone of intermediate hardness (101-400 mg/L) extends through most of the central part of the county, which may indicate that the original soft water in the Dakota has mixed with very hard water from underlying aquifers. Chloride concentrations exceed $500 \mathrm{mg} / \mathrm{L}$ in the Dakota water in western Brown County (Koch and Bradford, 1976, fig. 29), but such large concentrations are rare in Spink County except near the northwestern corner. 


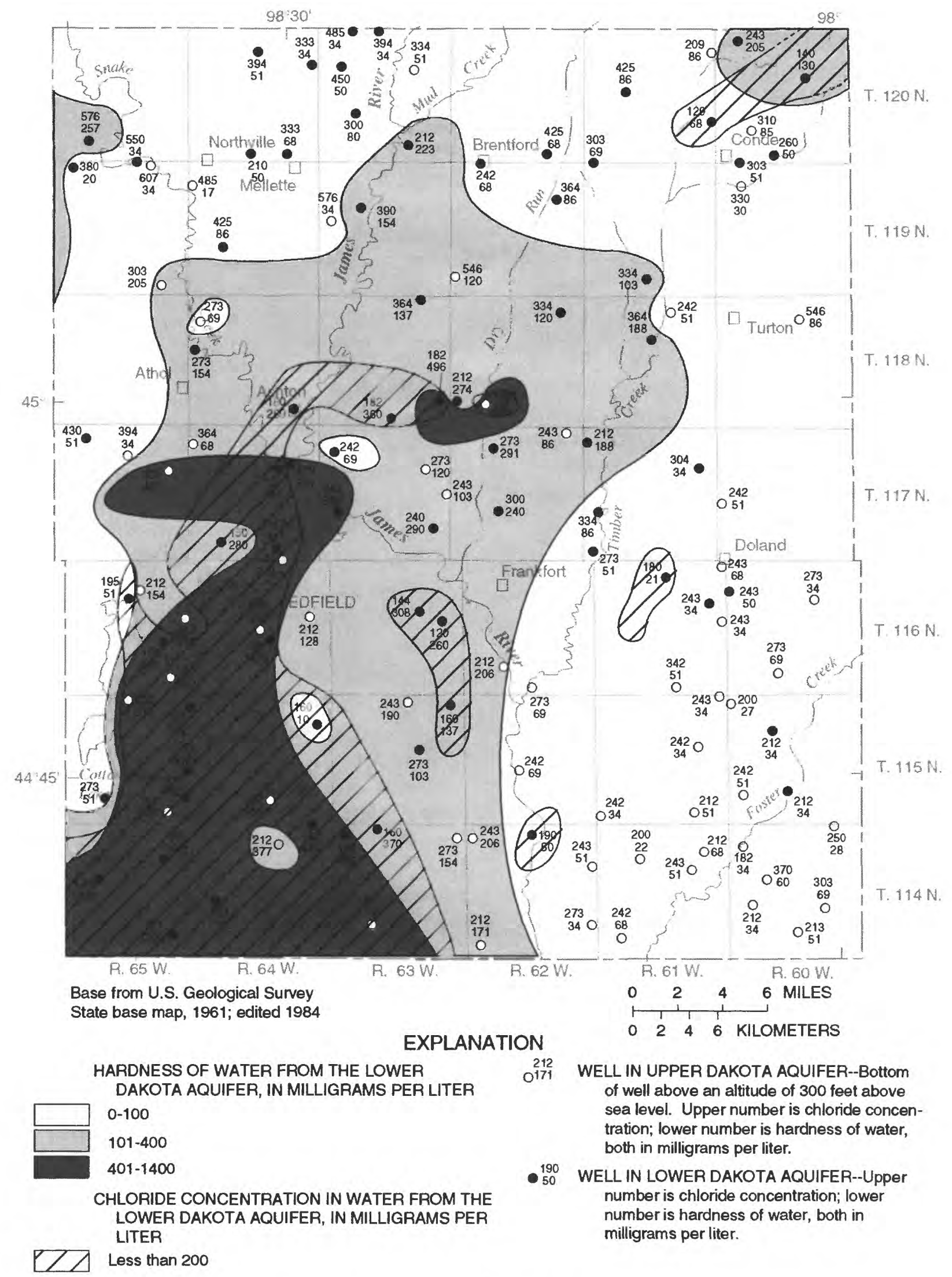

Figure 24. Hardness and chloride concentrations in water from the Dakota aquifer. 
Water samples collected from wells tapping the Dakota aquifer in Spink County did not exceed the EPA Primary MCL's for any regulated constituent with the following exceptions: one sample out of 98 that were analyzed for fluoride exceeded the MCL of $4.0 \mathrm{mg} / \mathrm{L}$; one sample out of 12 that were analyzed for cadmium exceeded the MCL of $5 \mu \mathrm{g} / \mathrm{L}$; and one sample out of 12 that were analyzed for lead exceeded the MCL of $15 \mu \mathrm{g} / \mathrm{L}$. It should be noted that concentrations of trace metals typically are very low in natural waters, and therefore special collection and handling procedures are now required for more accurate determinations of these constituents. Water samples discussed in this report were not collected using those procedures, and therefore the very few unusually large concentrations could represent contamination introduced during sampling or processing.

The median concentrations of dissolved solids, sulfate, iron, and manganese in water samples collected from the Dakota aquifer are near or exceed the EPA SMCL's of $500 \mathrm{mg} / \mathrm{L}, 250 \mathrm{mg} / \mathrm{L}, 300 \mu \mathrm{g} / \mathrm{L}$, and $50 \mu \mathrm{g} / \mathrm{L}$, respectively (U.S. Environmental Protection Agency, 1994a). Also, one sample out of eight that were analyzed for zinc exceeded the SMCL of $5,000 \mu \mathrm{g} / \mathrm{L}$. Boron concentrations in water from the Dakota aquifer may exceed recommended limits for irrigation of boron-sensitive crops (U.S. Environmental Protection Agency, 1986).

\section{Inyan Kara-Sundance Aquifer}

There are no water-quality analyses in the USGS water-quality data base for samples collected from the Inyan Kara-Sundance aquifer in Spink County. Generally, water from the Inyan KaraSundance aquifer in eastern South Dakota is very hard (about $1,000 \mathrm{mg} / \mathrm{L}$ ) and has concentrations of dissolved solids of 1,000 to $3,000 \mathrm{mg} / \mathrm{L}$ (U.S. Geological Survey, 1975).

\section{Minnelusa Aquifer}

No water-quality samples were collected from the Minnelusa aquifer in Spink County for this study. Generally, water from the Minnelusa aquifer is an extremely hard, calcium magnesium sulfate type, similar in concentrations of dissolved solids to water from the Fall River-Sundance-Minnelusa aquifer farther west in Hand and Hyde County (Koch, 1980, table 16). Based on data from adjacent areas, concentrations of dissolved solids probably are about $2,000 \mathrm{mg} / \mathrm{L}$ and the hardness probably is at least $1,200 \mathrm{mg} / \mathrm{L}$ and may exceed $1,500 \mathrm{mg} / \mathrm{L}$.

\section{Suitability of Ground Water for Various Uses}

Although most of the ground water in aquifers in glacial drift deposits and aquifers in bedrock in Spink County is slightly saline, the water is suitable for many uses. For some domestic and industrial uses, the only water treatment needed may be to reduce hardness and excessive concentrations of dissolved iron and manganese, which can cause clogging of well openings and pipes and staining of plumbing fixtures, utensils, food, and fabrics (table 9). Taste in drinking water can be affected by excessive concentrations of sulfate, sodium, chloride, copper, and zinc ions. Excessive concentrations of nitrate in water can be injurious to infants. Three out of 226 samples collected from wells tapping aquifers in glacial drift deposits in Spink County that were analyzed for nitrate nitrogen had concentrations in excess of the EPA MCL of $10 \mathrm{mg} / \mathrm{L}$ (U.S. Environmental Protection Agency, 1994a). The rare, large concentrations of nitrate nitrogen probably represent local contamination caused by sewage, barnyard waste, and/or fertilizer, possibly in combination with poor well construction; widespread nitrate-nitrogen concentrations are not a problem in any of the aquifers in Spink County.

Water that has large concentrations of dissolved solids, particularly sodium, and/or large concentrations of boron, such as the Deep James aquifer and all of the aquifers in the bedrock, generally is unsuitable for irrigation use. Fluoride concentration in some water from the Dakota aquifer and deeper bedrock aquifers generally exceeds the EPA SMCL of $2.0 \mathrm{mg} / \mathrm{L}$ but rarely exceeds the MCL of $4.0 \mathrm{mg} / \mathrm{L}$ for drinking water. Excessive amounts of fluoride in drinking water may cause mottling (dental fluorosis) of children's teeth or possible skeletal fluorosis, a serious bone disorder.

The general suitability of water for irrigation from the aquifers in surficial deposits can be determined by use of the South Dakota irrigation-water diagram (fig. 25). The diagram is based on South Dakota irrigation-water standards (revised Jan 7, 1982) and shows the State of South Dakota's waterquality and soil-texture requirements for the issuance of an irrigation permit. For example, water from one well in the Altamont aquifer can possibly be applied to sandy clay loams, silty clay loams, and clay loams (soil texture D) where the depth to a less permeable clay is only 20 to 60 inches (depth below land surface, code 3 ). It is possible to use this water because its 
Tabie 9. Significance of chemical and physical properties of water

[Modified from Howells, 1979. Limits, where given, are primary (mandatory) and secondary (recommended) limits for concentrations of substances in drinking water as set forth by the U.S. Environmental Protection Agency (1994). The unit milligrams per liter (mg/L) is approximately equivalent to parts per million. The unit micrograms per liter $(\mu \mathrm{g} / \mathrm{L})$ is approximately equivalent to parts per billion. The unit milliequivalents per liter (meq/L) is obtained by dividing the concentration, in milligrams per liter, by the combining weight of the ionic species]

\begin{tabular}{|c|c|c|}
\hline $\begin{array}{l}\text { Constituent or } \\
\text { property }\end{array}$ & Limit & Significance \\
\hline Specific conductance & & $\begin{array}{l}\text { A measure of the ability of water to conduct an electrical current; varies with temperature. } \\
\text { Magnitude depends on concentration, kind, and degree of ionization of dissolved constit- } \\
\text { uents; can be used to determine the approximate concentration of dissolved solids. } \\
\text { Values are reported in microsiemens per centimeter at } 25^{\circ} \text { Celsius. }\end{array}$ \\
\hline $\mathrm{pH}$ & $\begin{array}{l}\text { 6.5-8.5 units } \\
\text { (recommended) }\end{array}$ & $\begin{array}{l}\text { A measure of the hydrogen ion concentration; } \mathrm{pH} \text { of } 7.0 \text { indicates a neutral solution, } \mathrm{pH} \\
\text { values smaller than } 7.0 \text { indicate acidity, } \mathrm{pH} \text { values larger than } 7.0 \text { indicate alkalinity. } \\
\text { Water generally becomes more corrosive with decreasing } \mathrm{pH} \text {; however, excessively alka- } \\
\text { line water also may be corrosive. }\end{array}$ \\
\hline Temperature & & $\begin{array}{l}\text { Affects the usefulness of water for many purposes. Generally, users prefer water of uni- } \\
\text { formly low temperature. Temperature of ground water tends to increase with increasing } \\
\text { depth to the aquifer. }\end{array}$ \\
\hline $\begin{array}{l}\text { Hardness (as } \\
\left.\mathrm{CaCO}_{3}\right)\end{array}$ & & $\begin{array}{l}\text { Related to the soap-consuming characteristics of water; results in formation of scum when } \\
\text { soap is added. May cause deposition of scale in boilers, water heaters, and pipes. Hard- } \\
\text { ness equivalent to the bicarbonate and carbonate in water is called carbonate hardness; } \\
\text { hardness in excess of this concentration is called noncarbonate hardness. Water that has a } \\
\text { hardness less than } 61 \mathrm{mg} / \mathrm{L} \text { is considered soft; } 61-120 \mathrm{mg} / \mathrm{L} \text {, moderately hard; } 121 \text { - } \\
180 \mathrm{mg} / \mathrm{L} \text {, hard; and more than } 180 \mathrm{mg} / \mathrm{L} \text {, very hard. }\end{array}$ \\
\hline $\begin{array}{l}\text { Calcium plus } \\
\text { magnesium }\end{array}$ & & Cause most of the hardness and scale-forming properties of water (see hardness). \\
\hline $\begin{array}{l}\text { Sodium plus } \\
\text { potassium }\end{array}$ & & $\begin{array}{l}\text { Large concentrations may limit use of water for irrigation and industrial use and, in combi- } \\
\text { nation with chloride, give water a salty taste. Abnormally large concentrations may indi- } \\
\text { cate natural brines, industrial brines, or sewage. }\end{array}$ \\
\hline Percent sodium & & $\begin{array}{l}\text { Ratio of sodium to total cations in milliequivalents per liter expressed as a percentage. } \\
\text { Important in irrigation waters; the greater the percent sodium, the less suitable the water } \\
\text { for irrigation. }\end{array}$ \\
\hline $\begin{array}{l}\text { Sodium-adsorption } \\
\text { ratio (SAR) }\end{array}$ & & $\begin{array}{l}\text { A ratio used to express the relative activity of sodium ions in exchange reactions with soil. } \\
\text { Important in irrigation water; the greater the SAR, the less suitable the water for irriga- } \\
\text { tion. }\end{array}$ \\
\hline Bicarbonate & & In combination with calcium and magnesium forms carbonate hardness. \\
\hline Sulfate & $\begin{array}{l}250 \mathrm{mg} / \mathrm{L} \\
\text { (recommended) }\end{array}$ & $\begin{array}{l}\text { Sulfates of calcium and magnesium form hard scale. Large concentrations of sulfate have a } \\
\text { laxative effect on some people and, in combination with other ions, give water a bitter } \\
\text { taste. }\end{array}$ \\
\hline Chloride & $\begin{array}{l}250 \mathrm{mg} / \mathrm{L} \\
\text { (recommended) }\end{array}$ & $\begin{array}{l}\text { Large concentrations increase the corrosiveness of water and, in combination with sodium, } \\
\text { give water a salty taste. }\end{array}$ \\
\hline Fluoride & $\begin{array}{l}4.0 \mathrm{mg} / \mathrm{L} \\
\text { (mandatory) } \\
2.0 \mathrm{mg} / \mathrm{L} \\
\text { (recommended) }\end{array}$ & $\begin{array}{l}\text { Reduces incidence of tooth decay when optimum fluoride concentrations present in water } \\
\text { consumed by children during the period of tooth calcification. Potential health effects of } \\
\text { long-term exposure to elevated fluoride concentrations include dental and skeletal fluo- } \\
\text { rosis (U.S. Environmental Protection Agency, 1994b). }\end{array}$ \\
\hline Silica (as $\mathrm{SiO}_{2}$ ) & & $\begin{array}{l}\text { Forms hard scale in pipes and boilers and may form deposits on blades of steam turbines. } \\
\text { Inhibits deterioration of zeolite-type water softeners. }\end{array}$ \\
\hline Dissolved solids & $\begin{array}{l}500 \mathrm{mg} / \mathrm{L} \\
\text { (recommended) }\end{array}$ & $\begin{array}{l}\text { The total of all dissolved mineral constituents, usually expressed in milligrams per liter. } \\
\text { The concentration of dissolved solids may affect the taste of water. Water that contains } \\
\text { more than } 1,000 \mathrm{mg} / \mathrm{L} \text { is unsuitable for many industrial uses. Some dissolved mineral } \\
\text { matter is desirable, otherwise the water would have no taste. The dissolved solids con- } \\
\text { centration commonly is called the water's salinity and is classified as follows: fresh, } 0 \text { to } \\
1,000 \mathrm{mg} / \mathrm{L} \text {; slightly saline, } 1,000 \text { to } 3,000 \mathrm{mg} / \mathrm{L} \text {; moderately saline, } 3,000 \text { to } \\
10,000 \mathrm{mg} / \mathrm{L} \text {; very saline, } 10,000 \text { to } 35,000 \mathrm{mg} / \mathrm{L} \text {; and briny, more than } 35,000 \mathrm{mg} / \mathrm{L} \text {. }\end{array}$ \\
\hline
\end{tabular}


Table 9. Significance of chemical and physical properties of water-Continued

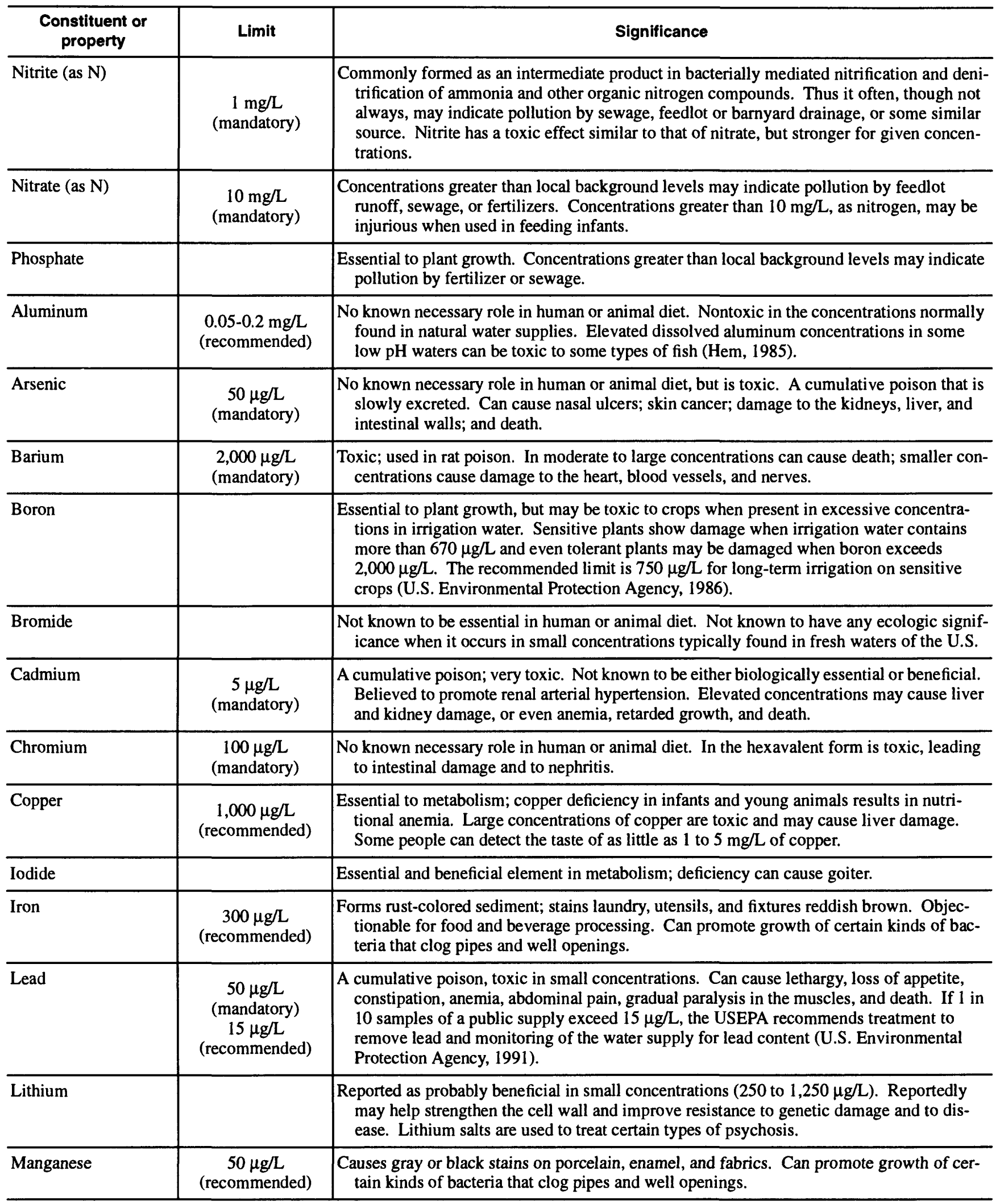


Table 9. Significance of chemical and physical properties of water-Continued

\begin{tabular}{|c|c|c|}
\hline $\begin{array}{l}\text { Constituent or } \\
\text { property }\end{array}$ & Limit & Significance \\
\hline Mercury & $\begin{array}{l}2 \mu \mathrm{g} / \mathrm{L} \\
\text { (mandatory) }\end{array}$ & $\begin{array}{l}\text { No known essential or beneficial role in human or animal nutrition. Liquid metallic mer- } \\
\text { cury and elemental mercury dissolved in water are comparatively nontoxic, but some } \\
\text { mercury compounds, such as mercuric chloride and alkyl mercury, are very toxic. Ele- } \\
\text { mental mercury is readily alkylated, particularly to methyl mercury, and concentrated by } \\
\text { biological activity. Potential health effects of exposure to some mercury compounds in } \\
\text { water include severe kidney and nervous system disorders (U.S. Environmental Protec- } \\
\text { tion Agency, 1994b). }\end{array}$ \\
\hline Molybdenum & & $\begin{array}{l}\text { In minute concentrations, appears to be an essential nutrient for both plants and animals, but } \\
\text { in large concentrations may be toxic. }\end{array}$ \\
\hline Nickel & $\begin{array}{l}100 \mu \mathrm{g} / \mathrm{L} \\
\text { (mandatory) }\end{array}$ & Very toxic to some plants and animals. Toxicity for humans is believed to be very minimal. \\
\hline Silver & $\begin{array}{l}100 \mu \mathrm{g} / \mathrm{L} \\
\text { (recommended) }\end{array}$ & $\begin{array}{l}\text { Causes permanent bluish darkening of the eyes and skin (argyria). Where found in water is } \\
\text { almost always from pollution or by intentional addition. Silver salts are used in some } \\
\text { countries to sterilize water supplies. Toxic in large concentrations. }\end{array}$ \\
\hline Strontium & & $\begin{array}{l}\text { Importance in human and animal nutrition is not known, but believed to be essential. Tox- } \\
\text { icity believed very minimal--no more than that of calcium. }\end{array}$ \\
\hline Vanadium & & $\begin{array}{l}\text { Not known to be essential to human or animal nutrition, but believed to be beneficial in trace } \\
\text { concentrations. May be an essential trace element for all green plants. Large concentra- } \\
\text { tions may be toxic. }\end{array}$ \\
\hline Zinc & $\begin{array}{l}5,000 \mu \mathrm{g} / \mathrm{L} \\
\text { (recommended) }\end{array}$ & $\begin{array}{l}\text { Essential and beneficial in metabolism; its deficiency in young children or animals will } \\
\text { retard growth and may decrease general body resistance to disease. Seems to have no ill } \\
\text { effects even in fairly large concentrations }(20,000 \text { to } 40,000 \mathrm{mg} / \mathrm{L}) \text {, but can impart a } \\
\text { metallic taste or milky appearance to water. Zinc in drinking water commonly is derived } \\
\text { from galvanized coatings of piping. }\end{array}$ \\
\hline
\end{tabular}




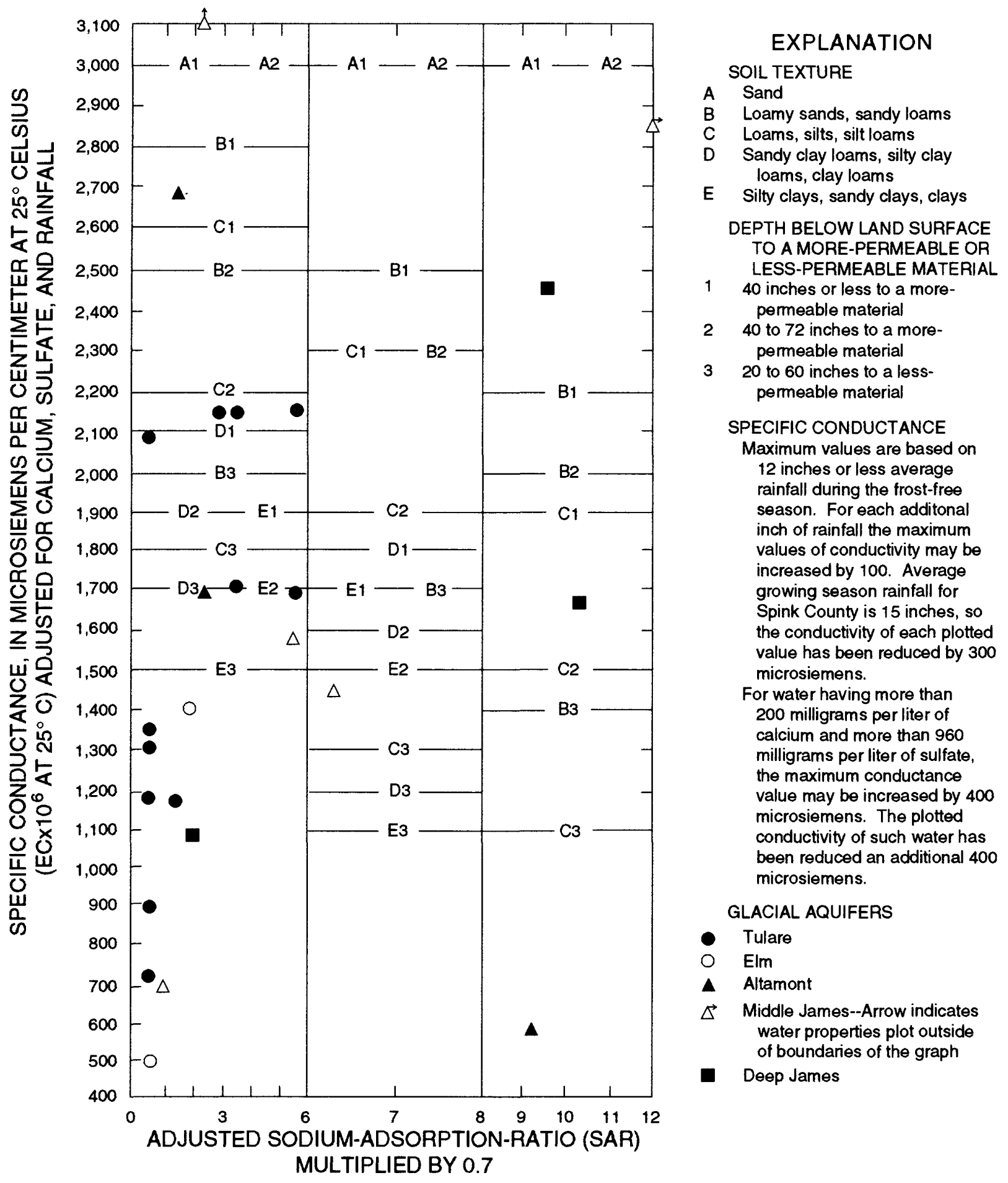

Figure 25. South Dakota irrigation-water classification diagram (based on South Dakota standards (revised Jan. 7 , 1982) for maximum allowable specific conductance and adjusted sodium-adsorption-ratio values for which an irrigation permit can be issued for applying water under various soil-texture conditons. Water can be applied under all conditions at or above the plotted point, but not below it, provided other conditions as defined by the State Conservation Commission are met from (Koch, 1983)). 
specific conductance $(1,690 \mu \mathrm{S} / \mathrm{cm}$ (microsiemens per centimeter at $25^{\circ} \mathrm{C}$ )) adjusted for calcium, sulfate, and rainfall) plots below the D3-E2 line at $1,690 \mu \mathrm{S} / \mathrm{cm}$. Some water samples from the Tulare, Altamont, Middle James, and Deep James aquifers plot in the upper half or in the right column of the diagram and are classified as being unsuitable for irrigating the clayey soils that are prevalent in Spink County. Most of the ground water that has a sodium concentration greater than $300 \mathrm{mg} / \mathrm{L}$ (fig. 23) is unsuitable for irrigating silty or clayey loams, even where there is more permeable soil at a depth of 40 inches or less.

\section{WATER USE}

Withdrawal of water for use in Spink County during 1990 was about 22,000 acre-feet. Withdrawal of surface water was about 1,000 acre-feet, 70 percent of which was for livestock and 30 percent for irrigation. Withdrawal of ground water in 1990, summarized in table 10 , was nearly 21,000 acre-feet.

Ground-water use in 1990 was 60 percent larger than that reported in 1985; the increased usage was caused by increases in acres irrigated and head of livestock raised, not by drought. In 1990, Spink County ranked second among South Dakota counties in the volume of ground water used for irrigation. All of the ground water used for irrigation, about 15,000 acre-feet, was pumped from aquifers in glacial drift, and slightly more than 13,000 acre-feet ( 88 percent) of that was water from the Tulare aquifer. Other uses of ground water, most of which came from flowing wells that tap the Dakota aquifer in the bedrock, include more than 4,600 acre-feet for watering livestock, 1,090 acre-feet for rural domestic use, and 348 acre-feet for municipal use. An additional 100 acre-feet of water was supplied to six towns by the WEB Rural Water System, which obtains its water from the Missouri River, more than 100 miles to the west. By 1991 , most towns in Spink County had connected to the WEB system as had most farms in the northern part of the county. Unused flow from 1,600 flowing artesian wells that tap aquifers in the bedrock is estimated to be 4.6 million gallons per day, or more than 5,000 acre-

Table 10. Estimated withdrawal of ground water in 1990

\begin{tabular}{|c|c|c|c|c|c|c|c|c|c|c|}
\hline \multirow{2}{*}{ Source } & \multicolumn{2}{|c|}{ Total } & \multicolumn{2}{|c|}{ Municipal $^{1}$} & \multicolumn{2}{|c|}{ Rural-domestic } & \multicolumn{2}{|c|}{ Livestock } & \multicolumn{2}{|c|}{ Irrigation } \\
\hline & Acre-feet & Percent & Acre-feet & Percent & Acre-feet & Percent & Acre-feet & Percent & Acre-feet & Percent \\
\hline \multicolumn{11}{|c|}{ GLACIAL AQUIFERS } \\
\hline Tulare & 13,228 & 63.1 & 0 & 0 & 78 & 0.4 & 60 & 0.3 & 13,090 & 62.4 \\
\hline Elm & 14 & 1 & 0 & 0 & 7 & 0 & 7 & 0 & 0 & 0 \\
\hline Altamont & 458 & 2.2 & 0 & 0 & 3 & 0 & 3 & 0 & 452 & 2.2 \\
\hline Middle James & 1,230 & 5.9 & 0 & $\mathbf{0}$ & 2 & 0 & 28 & .1 & 1,200 & 5.7 \\
\hline Deep James & 168 & .8 & 0 & 0 & 0 & 0 & ${ }^{2} 0$ & 0 & 168 & .8 \\
\hline Subtotal & 15,098 & ${ }^{3} 72.0$ & $\mathbf{0}$ & $\mathbf{0}$ & 90 & ${ }^{3} .5$ & 98 & .4 & 14,910 & 71.1 \\
\hline \multicolumn{11}{|c|}{ BEDROCK AQUIFERS } \\
\hline Niobrara & 10 & .1 & 0 & 0 & ${ }^{2} 0$ & $\mathbf{0}$ & 10 & .1 & 0 & 0 \\
\hline Dakota & ${ }^{4} 5,848$ & 27.9 & $5_{348}$ & 1.7 & 1,000 & 4.8 & 4,500 & 21.5 & 0 & 0 \\
\hline Inyan Kara & 6 & 0 & 0 & 0 & 0 & 0 & 6 & 0 & 0 & 0 \\
\hline Sundance-Minnelusa & 0 & 0 & 0 & $\mathbf{0}$ & 0 & $\mathbf{0}$ & 0 & $\mathbf{0}$ & 0 & 0 \\
\hline Subtotal $^{3}$ & 5,864 & 28.0 & 348 & 1.7 & 1,000 & 4.8 & 4,516 & 21.6 & 0 & 0 \\
\hline Total, all aquifers & 20,962 & 100.0 & 348 & 1.7 & 1,090 & ${ }^{3} 5.2$ & 4,614 & 22.0 & 14,910 & 71.1 \\
\hline
\end{tabular}

${ }^{1}$ Another 100 acre-feet from the Missouri River supplied by the WEB Rural Water System.

${ }^{2}$ Less than 1 acre-foot.

${ }^{3}$ Total percentage may not equal sum of components because of rounding.

${ }^{4}$ About 85 percent is unused flow from wells.

${ }^{5}$ Includes pumpage by South Dakota Developmental Center, Redfield ( 95 acre-feet). 
feet in 1990; this water creates or enhances local wetlands and wildlife habitat.

Data on irrigation withdrawals were obtained from reports of the DENR. Other data were reported by municipalities and by the WEB Rural Water System, or were estimated from population figures and average-per-capita use (F.D. Amundson and R.D. Benson, U.S. Geological Survey, oral commun., 1991).

\section{EFFECTS OF DEVELOPMENT}

\section{Surface Water}

The main effect of development of surfacewater resources has been the loss of about 9,000 acrefeet annually, mainly through increased evapotranspiration. This loss is composed of beneficial pumpage from the James River and tributaries for irrigation, about 300 acre-feet; withdrawals for livestock, about 700 acre-feet; and the average increase in evaporation from reservoirs, about 8,000 acre-feet.

\section{Ground Water}

Large water-level declines can cause a capture of ground-water flow within the zone of influence. This can result in storage of water that otherwise might be discharged to sloughs or streams or lost to evapotranspiration without beneficial use. Large water-level declines also result in ground-water storage capacity for subsequent recharge. The small average recharge to aquifers means that over the dry part of a climatic cycle, relatively large declines in water level may occur in a given aquifer in glacial deposits. The capture, or storage, of water that otherwise would have been lost without beneficial use helps to minimize this large water-level decline. The large recharge that occurs during wet years, such as 1983-86, generally raises water levels to predevelopment levels. Knowledge of this behavior of the glacial drift aquifers in Spink County is important to the efficient development and use of these aquifers. That is, it is the total decline in water level (an easily measured representation of the total decrease in the volume of water stored in the aquifer) during the dry part of a climatic cycle, as compared to the total rise in water level (total increase in the volume of water stored in the aquifer) during the wet part of that same climatic cycle, that is relevant on a county scale. Therefore, year-to-year declines in water level are not necessarily significant in indicating overdevelopment of an aquifer.

\section{Effects of Pumping Wells on Water Levels}

Withdrawals of ground water in Spink County have caused water levels to decline as much as 1.5 feet per year for aquifers in glacial deposits and as much as 4.2 feet per year for bedrock aquifers. Although water levels would be expected to decline until pumpage stabilizes and recharge balances discharge, the effect is not expected to appreciably reduce the yields of pumping wells. This is because most aquifers in Spink County are artesian and a decline in artesian head does not reduce the saturated thickness of the aquifer; rather, it only slightly reduces the efficiency and yield of individual wells.

Effects of withdrawals from wells that tap major aquifers in the glacial drift in Spink County generally are small because of large transmissivities and extensive recharge. Drawdown of water levels in a confined (artesian) aquifer theoretically can be 2 to 10 times (or more) larger than for an unconfined (water-table) aquifer (tables 11 and 12). For example, drawdown at a distance of 1,000 feet from a well pumping 1,000 gallons per minute for 100 days would be 3 feet for unconfined conditions, but 12 feet for a confined aquifer of the same transmissivity (the assumptions in

Table 11. Theoretical drawdown ${ }^{1}$ for unconfined (watertable) conditions

[Theoretical drawdown, in feet, at various distances from a well pumping continuously at 1,000 gallons per minute from an aquifer in unconsolidated deposits under unconfined conditions and no recharge. The aquifer is assumed to be infinite in areal extent ${ }^{2}$. Transmissivity $=13,000$ square feet per day; specific yield $=0.2$ ]

\begin{tabular}{cccccccc}
\hline $\begin{array}{c}\text { Time since } \\
\text { pumping } \\
\text { started }\end{array}$ & \multicolumn{5}{c}{$\begin{array}{c}\text { Theoretical drawdown, in feet, at given } \\
\text { distance from pumping well, in feet }\end{array}$} \\
\cline { 2 - 7 } & 100 & 300 & 500 & 700 & 1,000 & 5,000 \\
\hline 1 day & 3 & 1 & 0 & 0 & 0 & 0 \\
10 days & 6 & 3 & 2 & 2 & 1 & 0 \\
100 days & 8 & 6 & 5 & 4 & 3 & 0 \\
1 year & 10 & 7 & 6 & 5 & 5 & 1 \\
\hline
\end{tabular}

${ }^{1}$ Theoretical drawdown is calculated from curves showing response to pumping a fully penetrating well in an unconfined aquifer. Observation wells are open at the middle of the aquifer (Lohman, 1972, pl. 6).

${ }^{2}$ Because the aquifers in unconsolidated deposits in Spink County are limited in areal extent, the actual drawdown may be greater than shown because of nearby relatively impermeable boundaries. 
tables 11 and 12 are reasonable for the thicker parts of major aquifers in Spink County). Either doubling the pumping rate or halving the transmissivity of the aquifer theoretically would have the effect of doubling drawdown values, if other conditions remain the same and there is no recharge. Under natural conditions, there is a greater decline in water level and a larger cone of depression if there are additional pumping wells and/or if there are nearby, relatively impermeable boundaries. The water-level decline is less if there is increasing recharge or if there are increases in transmissivity and/or specific yield within the cone of depression.

Tabie 12. Theoretical drawdown ${ }^{1}$ for confined (artesian) conditions

[Theoretical drawdown, in feet, at various distances from a well pumping continuously at 1,000 gallons per minute from an aquifer in unconsolidated deposits under confined conditions and no recharge. The aquifer is assumed to be infinite in areal extent ${ }^{2}$. Transmissivity $=13,000$ square feet per day; storage coefficient $=0.0001]$

\begin{tabular}{ccccccc}
\hline $\begin{array}{c}\text { Time since } \\
\text { pumping } \\
\text { started }\end{array}$ & \multicolumn{5}{c}{$\begin{array}{c}\text { Theoretical drawdown, in feet, at given } \\
\text { distance from pumping well, in feet }\end{array}$} \\
\cline { 2 - 7 } & $\mathbf{1 0 0}$ & $\mathbf{3 0 0}$ & $\mathbf{5 0 0}$ & $\mathbf{7 0 0}$ & $\mathbf{1 , 0 0 0}$ & $\mathbf{5 , 0 0 0}$ \\
\hline 1 day & 12 & 9 & $\mathbf{8}$ & 7 & 6 & 3 \\
10 days & 14 & 12 & 11 & 10 & 9 & 6 \\
100 days & 17 & 15 & 13 & 13 & 12 & 8 \\
1 year & 19 & 16 & 15 & 14 & 14 & 10 \\
\hline
\end{tabular}

${ }^{1}$ Theoretical drawdown is calculated from the Theis type curve (Lohman, 1972, pl. 6). The effects of pumping a well in a confined aquifer will nearly always be much larger than shown here, because of departure from idealized, theoretical conditions/assumptions.

${ }^{2}$ Because the aquifers in unconsolidated deposits in Spink County are limited in areal extent, the actual drawdown may be greater than shown because of nearby relatively impermeable boundaries.

Construction and use of 23 irrigation wells during the last 40 years in the East James Management Unit of the Tulare aquifer caused water levels to decline more than 4 feet between 1979 and 1984 throughout an area of 20 square miles east of the James River (James Goodman, South Dakota Department of Environment and Natural Resources, oral commun., 1989). Large recharge of the aquifers in the drift from 1983-86 reversed this declining trend in water levels (a county-wide phenomenon). A comparison of water-level changes between spring 1982 and spring 1990 shows that water levels recovered locally as much as 8.4 feet in T. 115 N., R. $65 \mathrm{~W}$. and 24.2 feet in T. 117 N., R. 60 W., but have declined as much as 3 to 5 feet in several areas within the East James Management Unit (fig. 26). The local declines were caused by a 50- to 100 -percent increase in pumpage of nearby irrigation wells from 1988-90.

The areal decline in water level for the Tulare aquifer in Spink County and in northern Beadle County under long-term pumpage ( 50 years) at the rate estimated during 1978 (9,800 acre-feet per year) was simulated by a numerical ground-water-flow model (Kuiper, 1984, p. 44). The model calculated an average water-level decline of about 3 feet west of the James River, but nearly 14 feet east of the river.

If the water level declines 14 -feet over 50 years, as simulated by the numerical model for the area east of the James River, much of the aquifer there still will be under artesian conditions. Even if there is a gradual increase in total pumpage, the rate of decline of water levels will become substantially slower as the aquifer shifts from artesian to water-table conditions (tables 11 and 12). Thus, the main effects of a gradual increase of pumpage in the East James Management Unit of the Tulare aquifer should be an increased recapture of ground water that now is discharged by natural evapotranspiration, a decrease in any natural ground-water discharge to surface water, a decrease in the rate of decline of water levels, and a large local decrease of sustainable well yields where drawdowns of water levels in pumping wells are excessive because of limited recharge (Kuiper, 1984, fig. 34). Continued monitoring of water levels and pumping rates, additional test drilling, and possibly a detailed numerical-model study, would be useful to verify these conclusions and to delineate more accurately those areas where excessive drawdown might occur.

\section{Effects on Water Quality}

In Spink County, the quality of water in aquifers in glacial drift deposits can change as a result of intensive pumping of wells, leakage from corroded casings of flowing wells, or excavation of dugouts, drainage ditches, and borrow pits adjacent to roads. Intensive pumping of wells lowers water levels in aquifers, thereby inducing recharge of water of different quality from adjacent deposits. Water recharged from swampy, poorly drained areas may contain high concentrations of dissolved solids because of concentration of salts by evapotranspiration (Koch and Bradford, 1976, p. 28). Dissolved solids in ground water used for irrigation may again percolate to an aquifer and increase aquifer salinity if applied in a recharge area. 


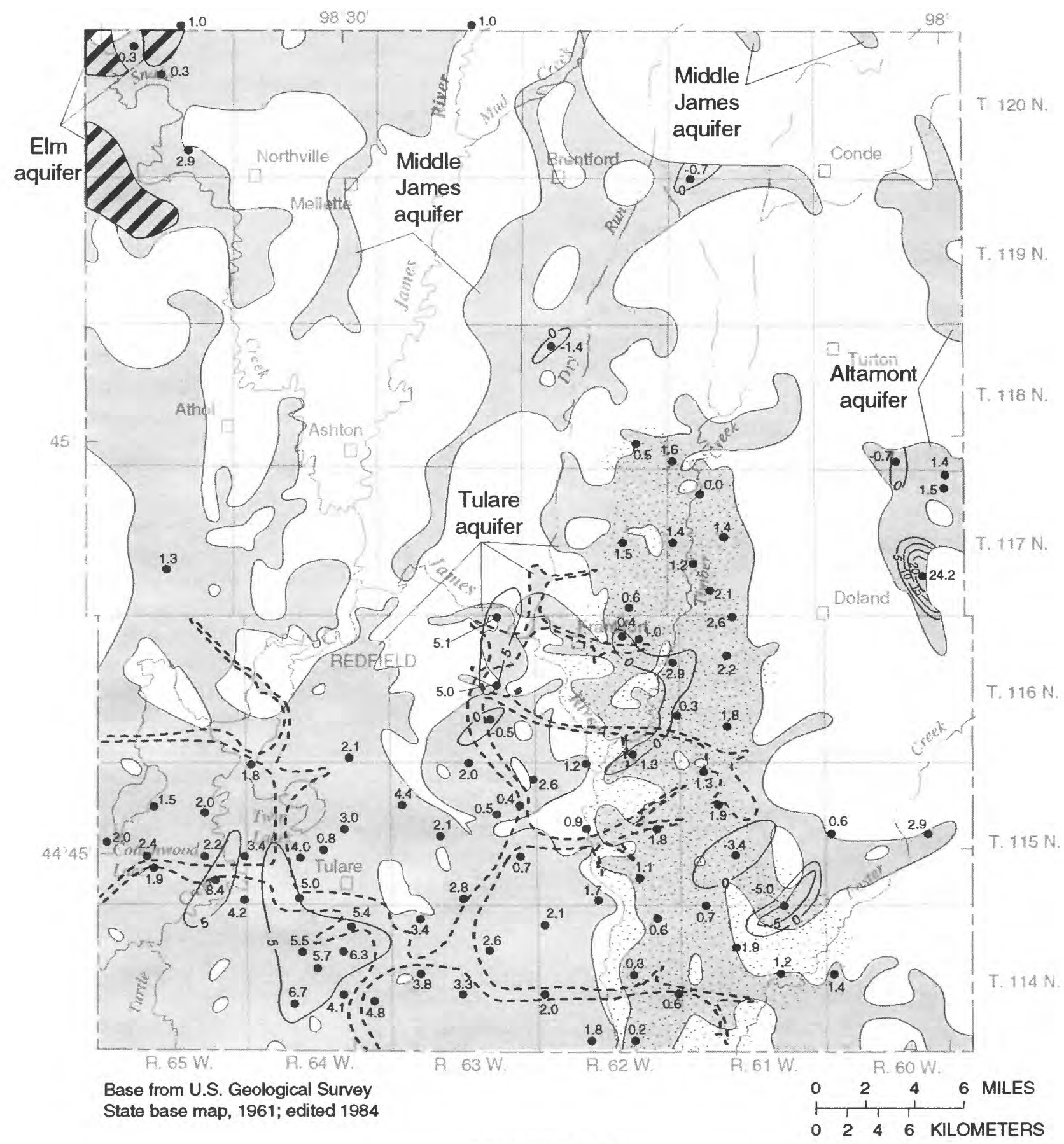

EXPLANATION

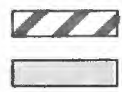

APPROXIMATE AREA UNDERLAIN BY ELM AQUIFER

$-5-$

APPROXIMATE AREA UNDERLAIN BY TULARE, MIDDLE JAMES, AND ALTAMONT AQUIFERS

:THE TULARE AQUIFER THAT ARE PART OF THE SAME DEPOSITIONIAL EPISODE AS THE DEEP JAMES AQUIFER (see figure 12)

APPROXIMATE AREA OF THE EAST JAMES MANAGMENT UNIT
LINE OF EQUAL WATER-LEVEL CHANGE, IN FEET--Contour interval 5 feet

- 1.4 OBSERVATION WELL--Number is water-level change, in feet, between spring 1982 and spring 1990. A minus (-) indicates a decline in water level.

Figure 26. Water-level changes in the Tulare and other glacial aquifers between spring 1982 and spring 1990. 
Leaking of corroded casings of about 2,000 flowing bedrock wells completed in the Dakota aquifer over the past century may have caused sodium sulfate type water from the Dakota aquifer to seep into shallower aquifers over broad areas and make the quality of the water less suitable for irrigation use. The leakage may affect the quality of water in glacial deposits within a radius of one-half mile of old flowing wells. Fluoride concentrations in water from these zones range from 0.4 to $0.8 \mathrm{mg} / \mathrm{L}$, but outside of the zones may be only about $0.1 \mathrm{mg} / \mathrm{L}$ (Hopkins and Petri, 1962, table F). The median concentration of fluoride in water from the Dakota aquifer is $2.7 \mathrm{mg} / \mathrm{L}$, whereas fluoride concentrations in water from aquifers in the drift were less than $1.5 \mathrm{mg} / \mathrm{L}$ (table 8).

Excavation of dugouts, drainage ditches, and borrow pits along roads in poorly drained areas increases losses by evapotranspiration. This can cause ground water to become more saline. A comparison of the specific conductance of water from six shallow wells in borrow pits with the specific conductance of water from six nearby test holes in fields showed that the borrow-pit water had a larger specific conductance and was therefore more saline in all cases. The conductance of water beneath the borrow pits averaged $4,100 \mu \mathrm{S} / \mathrm{cm}$, but beneath the fields it averaged only $1,900 \mu \mathrm{S} / \mathrm{cm}$.

\section{SUMMARY AND CONCLUSIONS}

Spink County, an agricultural area of about 1,505 square miles, is in the flat to gently rolling James River lowland of east-central South Dakota. The water resources are characterized by the highly variable flows of the James River and its tributaries and by aquifers both in glacial deposits of sand and gravel, and in shale and sandstone in the bedrock. Glacial aquifers underlie about half of the county and bedrock aquifers underlie most of the county.

The James River is an intermittent prairie stream that drains nearly 8,900 square miles north of Spink County and has an average annual discharge of about 124 cubic feet per second where it enters the county. The discharge is augmented by the flows of Snake and Turtle Creeks, each of which has an average annual flow of about 25 to 30 cubic feet per second. Streamflow is unreliable as a water supply because precipitation, which averages 18.5 inches annually, is erratic both in volume and in distribution, and because the average annual potential evapotrans- piration rate is 43 inches. The flow of tributaries generally ceases by summer, and zero flows are common in the James River in fall and winter.

Aquifers of outwash sand and gravel have been deposited during several episodes of continental glaciation that left 50 to 100 feet of glacial drift over bedrock in much of the county. Glacial aquifers in unconsolidated deposits underlie 760 square miles and store about 3.3 million acre-feet of fresh to slightly saline water at depths of from near land surface to more than 500 feet below land surface. The Tulare aquifer, the most extensive of the aquifers in the glacial drift, has the largest average thickness (37 feet) and occurs mostly in the southern half of the county. Yields of properly developed wells in aquifers in the drift range from 2 to 1,200 gallons per minute. Withdrawals from these aquifers, mostly for irrigation, totaled about 15,000 acre-feet in 1990. Water levels in observation wells generally have declined less than 15 feet over several decades of increasing pumpage for irrigation, but locally have declined nearly 30 feet. Water levels generally recovered during the 1983-86 wet period, when there was less irrigation. The level in the East James Management Unit of the Tulare aquifer resumed its decline below previous low levels because of a 50- to 100-percent increase in pumpage of nearby irrigation wells during 1988-90. Continued monitoring of water levels and pumping rates, additional test drilling, and a detailed numerical model study possibly would be useful for the East James Management Unit in order to determine if there will be excessive drawdowns in some areas and if water levels will continue to decline if pumpage is allowed to increase over many years.

Bedrock aquifers store more than $\mathbf{4 0}$ million acre-feet of slightly to moderately saline water at depths of from 80 to about 1,300 feet below land surface. Yields of properly developed wells in bedrock are reported to range from 2 to 600 gallons per minute. The artesian head of the Dakota aquifer has declined about 350 feet during the approximately 100 years since flowing wells were first completed in the aquifer. However, water levels locally have stabilized since 1982 because of a decrease in well use and increased use of water from rural water systems. Initial flows of from 4 to 30 gallons per minute of very hard water can be obtained in the southwestern part of the county where artesian heads of nearly 100 feet above land surface have been reported by drillers. Larger initial flows can be obtained from higher pressure aquifers beneath the Dakota, but the extent of those aquifers beneath Spink County is unknown. 
The quality of water from aquifers in glacial drift deposits varies greatly, both within and between aquifers. Concentrations of dissolved solids in samples ranged from 151 to $9,610 \mathrm{mg} / \mathrm{L}$, and hardness of the water ranged from 84 to $3,700 \mathrm{mg} / \mathrm{L}$; both dissolved solids and hardness tend to be largest where aquifers are thin and of low permeability. Two of 109 samples from the Tulare aquifer and one of 112 samples from minor aquifers in the glacial drift exceeded the EPA Primary Drinking-Water Regulations Maximum Contaminant Level (MCL) for nitrate of $10 \mathrm{mg} / \mathrm{L}$. The median concentrations of dissolved solids, sulfate, iron, and manganese in some glacial aquifers are near or exceed the EPA Secondary Maximum Contaminant Levels (SMCL's). Some of the water from aquifers in glacial drift is suitable for irrigation use.

The quality of water from bedrock aquifers also varies greatly. Water from the Niobrara aquifer generally is a soft, sodium sulfate chloride type with a dissolved-solids concentration of about $1,500 \mathrm{mg} / \mathrm{L}$. Water from the Dakota aquifer varies from a soft, sodium sulfate type to an extremely hard, calcium magnesium sulfate type. Concentrations of dissolved solids (sum of constituents) in the Dakota ranged from about $1,620 \mathrm{mg} / \mathrm{L}$ to about $2,670 \mathrm{mg} / \mathrm{L}$, with a median of $2,110 \mathrm{mg} / \mathrm{L}$, and the hardness ranged from 10 to $1,400 \mathrm{mg} / \mathrm{L}$, with a median of $100 \mathrm{mg} / \mathrm{L}$. Median concentrations of total dissolved solids, sulfate, iron, and manganese in Dakota wells either are near or exceed EPA SMCL's. Water from aquifers below the Dakota generally is an extremely hard, calcium magnesium sulfate type. Concentrations of dissolved solids in the deeper aquifers (Inyan Kara-Sundance and Minnelusa) are about 2,000 $\mathrm{mg} / \mathrm{L}$ and the hardness is about $1,000 \mathrm{mg} / \mathrm{L}$ or greater. Dissolved solids, sodium, and boron concentrations in water from bedrock aquifers commonly are too large for the water to be suitable for irrigation use.

Although this was a comprehensive study, more detailed hydrologic studies may be useful locally where development of large supplies of water is planned. In particular, the heterogeneous nature of aquifers in glacial drift deposits indicates that additional drilling and testing would provide information to help assure that an aquifer under development has sufficient extent, thickness, and permeability for the sustained yield of the required quantity of water. Additional observation wells would be important for accurately determining the direction and rate of ground-water movement. Chemical analyses of water from observation wells can be used to determine if the quality of the water is satisfactory for an intended use and to delineate possible areas of contamination.

\section{SELECTED REFERENCES}

Barari, Assad, 1983, Hydrogeology of glacial till: South Dakota Geological Survey internal report, unpublished, 8 p.

Barari, Assad, and Cowman, T.C., 1988, Water movement in clayey till in eastern South Dakota: International Conference on fluid flow in fractured rocks, Symposium Proceedings, p. 69-84.

Barari, Assad, and Hedges, L.S., 1985, Movement of water in glacial till: International Association of Hydrogeologist Memoirs, v. 17, pt. 1 of Proceedings, p. 129-135.

Benson, R.D., 1983, A preliminary assessment of the hydrologic characteristics of the James River in South Dakota: U.S. Geological Survey Water-Resources Investigations Report 83-4077, 115 p.

1988, Analysis of flood-flow frequency, flow duration, and channel-forming flow for the James River in South Dakota: U.S. Geological Survey WaterResources Investigations Report 87-4208, 136 p.

Benson, R.D., Freese, M.E., Amundson, F.D., and Wipf, V.J., 1987, Drainage areas in the James River basin in eastern South Dakota: U.S. Geological Survey OpenFile Report 87-572, 1 p.

Briel, L.I., 1989, Dissolved-solids data for the James River salinity model, North Dakota and South Dakota: U.S. Geological Survey Open-File Report 89-43, 239 p.

Burch, S.L., 1981, Ground water study for the southern Spink-northern Beadle municipal water council: South Dakota Geological Survey Open-File Report No. 33-UR, 24 p.

Callahan, M.A., Slimak, M.W., Gabel, N.W., May, I.P., Fowler, C.F., Freed, J.R., Jennings, Patricia, Durfee, R.L., Whitmore, F.C., Maestri, Bruno, Mabey, W.R., Holt, B.R., and Gould, Constance, 1979, Water-related environmental fate of 129 priority pollutants, Volume I: Introduction and technical background, metals and inorganics, pesticides and PCBs: U.S. Environmental Protection Agency, Office of Water Planning and Standards, Office of Water and Waste Management, EPA-440/4-79-029a [variously paged].

CENDAK Drainage Steering Committee, 1987, Comparison of irrigated land in southern Alberta, Canada, with CENDAK area, South Dakota: South Dakota Geological Survey Open-File Report 8-BAS, 496 p. 
1988, Concluding report of CENDAK drainage investigations: U.S. Bureau of Reclamation, Billings, Montana, $117 \mathrm{p}$.

Christensen, C.M., 1963, Water supply for the city of Redfield: South Dakota Geological Survey Special Report 24, 32 p.

1977, Geology and water resources of McPherson, Edmunds, and Faulk Counties, South Dakota: Part I, Geology: South Dakota Geological Survey Bulletin 26, $58 \mathrm{p}$.

Cravens, S.J., and Ruedisili, L.C., 1987, Water movement in till of east-central South Dakota: Groundwater, v. 25 , no. 5, p. 555-560.

Darton, N.H., 1896, Preliminary report on artesian waters of a portion of the Dakotas: U.S. Geological Survey 17th Annual Report, Pt. 2, p. 603-694.

-1909, Geology and underground waters of South Dakota: U.S. Geological Survey Water-Supply Paper $227,156 \mathrm{p}$.

Derr, H.M., 1916, Sixth report of the State Engineer [South Dakota] for the period July 1, 1914, to June 30, 1916: Pierre, South Dakota, Office of State Engineer, 282 p.

Downey, J.S., 1986, Geohydrology of bedrock aquifers in the Northern Great Plains in parts of Montana, North Dakota, South Dakota, and Wyoming: U.S. Geological Survey Professional Paper 1402-E, 87 p.

Erickson, H.D., 1954, Artesian conditions in east central South Dakota: South Dakota Geological Survey Report of Investigations No. 74, $116 \mathrm{p}$.

1955, Artesian conditions in northeastern South Dakota: South Dakota Geological Survey Report of Investigations No. 77, 39 p.

Farnsworth, R.K., Thompson, E.S., and Peck, E.L., 1982, Evaporation atlas for the contiguous 48 United States: National Oceanic and Atmospheric Administration Technical Report NWS 33, 26 p.

Feth, J.H., and others, 1965, Preliminary map of the conterminous United States showing depth to and quality of shallowest ground water containing more than 1,000 parts per million dissolved solids: U.S. Geological Survey Hydrologic Investigations Atlas HA-199, 31 p, 2 sheets.

Flint, R.F., 1955, Pleistocene geology of eastern South Dakota: U.S. Geological Survey Professional Paper 262, $173 \mathrm{p}$.

Hamilton, L.J., 1982, Geology and water resources of McPherson, Edmunds, and Faulk Counties, South Dakota: Part II, Water resources: South Dakota Geological Survey Bulletin 25, 53 p.

1986, Geology and water resources of Clark County, South Dakota, Part II, Water resources: South Dakota Geological Survey Bulletin 29, 62 p.
Hedges, L.S., 1968, Geology and water resources of Beadle County, South Dakota: Part 1, Geology: South Dakota Geological Survey Bulletin 18, 66 p.

Helgerson, Ronald, and Duchossois, G.E., 1987, Geology and water resources of Hand and Hyde Counties, South Dakota: Part I, Geology: South Dakota Geological Survey Bulletin 28, $46 \mathrm{p}$.

Hem, J.D., 1985, Study and interpretation of the chemical characteristics of natural water: U.S. Geological Survey Water-Supply Paper 2254, 263 p.

Hopkins, W.B., and Petri, L.R., 1962, Data on wells and test holes and chemical analyses of ground water in the Lake Dakota plain area, Brown, Marshall and Spink Counties, South Dakota: South Dakota State Geological Survey and South Dakota State Water Resources Commission, Water Resources Report 1, $269 \mathrm{p}$.

1963 , Geology and ground-water resources of the Lake Dakota plain area, South Dakota: U.S. Geological Survey Water-Supply Paper 1539-T, 68 p.

Howells, L.W., 1979, Geohydrology of the Cheyenne River Indian Reservation, South Dakota: U.S. Geological Survey Hydrologic Investigations Atlas HA-585, 3 sheets.

Howells, L.W., and Stephens, J.C., 1968, Geology and water resources of Beadle County, South Dakota: Part II, Water resources: South Dakota Geological Survey Bulletin 18, $65 \mathrm{p}$.

Iles, D.L., and Barari, Assad, 1978, Ground water study for the city of Redfield: South Dakota Geological Survey Open-File Report No. 22-UR, 23 p.

Karl, T.R., Metcalf, L.K., Nicodemus, M.L., and Quayle, R.G., 1983, Statewide average climatic history: South Dakota 1890-1982: National Climatic Data Center Historical Climatology Series 6-1, 37 p.

Koch, N.C., 1970, A graphic representation of stream gain or loss as an aid in understanding streamflow characteristics: Water Resources Research, v. 6, no. 1, p. 239-245. 1980, Geology and water resources of Hand and Hyde Counties, South Dakota: Part II, Water resources: South Dakota Geological Survey Bulletin 28, $46 \mathrm{p}$.

1983, Irrigation-water classification diagram for South Dakota: South Dakota Academy of Science Proceedings, v. 62, p. 107-114.

1986, Post-Cretaceous uplift of the Sioux Quartzite ridge in southeastern South Dakota: U.S. Geological Survey Open-File Report 86-419, 10 p.

Koch, N.C., and Bradford, Wendell, 1976, Geology and water resources of Brown County, South Dakota: Part II, Water resources: South Dakota Geological Survey Bulletin 25, $53 \mathrm{p}$. 
Kuiper, L.K., 1984, Appraisal of the water resources of the eastern part of the Tulare aquifer, Beadle, Hand, and Spink Counties, South Dakota: U.S. Geological Survey Water-Resources Investigations Report 84-4078, $52 \mathrm{p}$.

Larimer, O.J., 1970, A proposed streamflow data program for South Dakota: U.S. Geological Survey Open-File Report, 46 p.

LaRocque, G.A., Jr., Jones, J.R., Rainwater, F.H., and others, 1955, Geology and ground-water hydrology of part of the James River valley in South Dakota, Appendix E - Aquifer tests: unpublished U.S. Geological Survey preliminary open-file report.

Leap, D.I., 1986, Geology and water resources of Brown County, South Dakota: Part I, Geology: South Dakota Geological Survey Bulletin 25, 48 p.

Limmer, D.R., and Fredrickson, Larry, 1975, Wetlands inventory-Spink County: South Dakota Department of Wildlife, Parks, and Forestry, Pittnam-Robertson Project W-75-R-18, Study no. L-15.1, 41 p.

Lohman, S.W., 1972, Ground-water hydraulics: U.S.Geological Survey Professional Paper 708, 70 p.

Lohman, S.W., and others, 1972, Definitions of selected ground-water terms-revisions and conceptual refinements: U.S. Geological Survey Water-Supply Paper 1988, $21 \mathrm{p}$.

Loucks, D.W., 1952, Twenty-third report of the State Engineer [South Dakota] for the period July 1, 1950, to June 30, 1952: Pierre, South Dakota, Office of State Engineer, 306 p.

Petri, L.R., and Larson, L.R., no date, Quality of water in selected lakes of eastern South Dakota: South Dakota Water Resources Commission Report of Investigations No. 1, 55 p.

Reeves, W.S., 1922, Drainage and flood control investigations in the James and Big Sioux River valleys, State of South Dakota: James and Big Sioux Valley Drainage Commission Report, 85 p.

Schmidt, A.E., 1967, Limnology of selected South Dakota lakes: Brookings, South Dakota State University, unpublished M.S thesis, $95 \mathrm{p}$.

Schoon, R.A., 1971, Geology and hydrology of the Dakota Formation in South Dakota: South Dakota Geological Survey Report of Investigations 104, 55 p.

Shepard, J.H., 1895, The artesian waters of South Dakota: South Dakota State College Experiment Station Bulletin 41, 76 p.

Stallman, R.W., 1964, Multiphase fluids in porous media-A review of theories pertinent to hydrologic studies: U.S. Geological Survey Professional Paper 411-E, $51 \mathrm{p}$.

Theis, C.V., 1935, The relation between the lowering of the piezometric surface and the rate and duration of discharge of a well using ground-water storage: American Geophysical Union Transactions, v. 16, pt. 2, p. 519-524.

Todd, J.E., 1909, Description of the Aberdeen-Redfield district, South Dakota: U.S. Geological Survey Geologic Atlas, Folio 165, 6 p.

U.S. Army Corps of Engineers, 1934, Report on the James River, North Dakota and South Dakota: 73rd Congress, 1st Session, House Document No. 83, 130 p.

U.S. Bureau of Reclamation, 1977, Basic data-alternative concepts, James River water management: Huron, South Dakota, 40 p.

1986, Report on drainage investigations and aquifer pumping test, Cendak Unit, Central South Dakota: $21 \mathrm{p}$.

U.S. Environmental Protection Agency, 1986, Quality criteria for water (updated May 1986), Update No. 2: Washington, D.C., Office of Water Regulations and Standards, EPA 440/5-86-001, 398 p. -1991 , Lead and copper role fact sheet: U.S. Environmental Protection Agency, Office of Water, EPA 570/9-91-400, 2 p.

1994a, Summary of EPA finalized National primary drinking water regulations: U.S. Environmental Protection Agency Region VIII, 7 p.

-1994b, National primary drinking water standards:

U.S. Environmental Protection Agency, Office of Water, EPA 810-F-94-001A, 4 p.

U.S. Geological Survey, 1957, Basic-data reports for Oahe Unit, James River Division, South Dakota:

Appendix A, Records of wells, test holes, and springs, 212 p.; Appendix B, Measurements of the water levels in wells, 230 p.; Appendix C, Logs of wells and test holes, 195 p.; Appendix D, Chemical analyses of water, $81 \mathrm{p}$.

1959, Compilation of records of surface waters of the United States through September 1950: U.S. Geological Survey Water-Supply Paper 1309, 672 p.

1964, Compilation of records of surface waters of the United States, October 1950 to September 1960, Part 6A, Missouri River Basin above Sioux City, Iowa: U.S. Geological Survey Water-Supply Paper 1729, $507 \mathrm{p}$.

1969, Surface water supply of the United States 1961-65, Part 6, Missouri River Basin, v. 2, Missouri River Basin from Williston, North Dakota, to Sioux City, Iowa: U.S. Geological Survey Water-Supply Paper 1917, 560 p.

1973, Surface water supply of the United States 1966-70, Part 6, Missouri River Basin, v. 2, Missouri River Basin from Williston, North Dakota, to Sioux City, Iowa: U.S. Geological Survey Water-Supply Paper 2117, 612 p. 
1975, Mineral and water resources of South Dakota: U.S. Congress, 94th, 1st Session, Interior and Insular Affairs Committee Print, 313 p.

1971-75, Water resources data for South Dakota, 1970-74--part 1. Surface-water records: U.S.

Geological Survey Water-Data Reports SD-70-1 to SD-74-1 (published annually).

1973-75, Water resources data for South Dakota, 1970-74--part 2. Water-quality records: U.S.

Geological Survey Water-Data Reports SD-70-2 to SD-74-2 (published annually).

1976-91, Water resources data for South Dakota, water years 1975-90: U.S. Geological Survey Water
Data Reports SD-75-1 to SD-91-1 (published annually).

1991, National Water summary, 1988-89 - Hydrologic events and floods and droughts: U.S. Geological Survey Water-Supply Paper 2375, 591 p.

U.S. Soil Conservation Service, 1954, Soil survey of Spink County, South Dakota: South Dakota Agricultural Research Station Bulletin 439, 145 p.

Wiche, G.J., Benson, R.D., and Emerson, D.G., 1989, Streamflow at selected gaging stations on the James River in North Dakota and South Dakota, 1953-82, with a section on climatology: U.S. Geological Survey Water-Resources Investigations Report 89-4039, 99 p. 